\title{
DIAGNÓSTICO DE PROJETOS DE EDUCAÇÃO AMBIENTAL EM ESCOLAS PÚBLICAS DAS ÁREAS DE PROTEÇÃO DE MANANCIAIS DA REPRESA BILLINGS
}

\section{DAGMAR SANTOS ROVERATTI}

Tese de Doutorado apresentada ao Departamento de Saúde Ambiental da Faculdade de Saúde Pública da Universidade de São Paulo para obtenção do Grau de Doutor.

Área de Concentração:Saúde Ambiental

OrIENTADOR: Prof. DR. SAMUEL MuRgel BRANCO.

São Paulo

2000

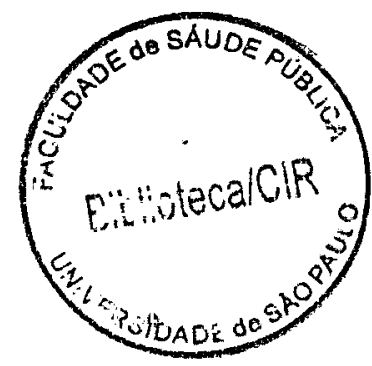


"E vem o gaturamo cantarilho nas roçadas de milho, o quero-quero circunvoando juncos. Multicor, a plumagem do socozinho vai cruzando o vôo horizontal das jaçanãs.

Repara, homem do asfalto, a seriema a preparar, no capim alto, seus disfarces, e a corruíra-do-brejo, a viuvinha, o lenhador-de-olho-branco, a saracura, todas essas aves que só existem nas gravuras dos livros, na empalhada vitrina dos museus... porque matamos o que era vida alada em nossa volta."

Carlos Drummond de Andrade 


\section{AGRADECIMENTOS}

Ao Prof. Dr. Samuel Murgel Branco pela orientação deste trabalho.

Ao Prof. Dr. Aristides Almeida Rocha pelo apoio concedido em todas as etapas do programa de doutorado.

À Profa. Dra. Maria Cecília Focesi Pelicioni pelas valiosas sugestões na elaboração do projeto e atenção na correção da versão final deste trabalho.

À Profa. Dra. Haydée Torres de Oliveira pela disponibilịdade em me receber, fornecendo suas sugestões e indicações de leituras para o aprimoramento desta tese.

À Juliana cuja amizade e dedicação mais uma vez foram fundamentais para que eu atingisse meus objetivos.

Aos professores, coordenadores e demais profissionais das escolas pela paciência e colaboração durante a coleta de dados.

Aos meus alunos da Fundação Santo André, Kátia e Carlos, pelo auxílio prestado durante a coleta de dados.

A todos aqueles que de forma direta ou indireta contribuíram para o execução deste trabalho. 


\section{RESUMO}

Roveratti DS. Diagnóstico de projetos de Educação Ambiental em escolas públicas das áreas de proteção de mananciais da Represa Billings. São Paulo; 1999.[Tese de Doutorado - Faculdade de Saúde Pública da USP].

Objetivo. O sistema escolar é fundamental para a prática da Educação Ambiental, devendo proporcionar uma análise dos problemas ambientais locais. Este diagnóstico foi elaborado visando fornecer um panorama da Educação Ambiental em escolas estaduais próximas da Represa Billings, verificando se a recuperação do reservatório e a "Lei de Proteção aos Mananciais" tem sido abordadas no currículo destas escolas. Metodologia. Foram analisadas informações de professores, levantadas por meio de questionário, em 58 escolas próximas à Represa Billings, situadas em Diadema, Ribeirão Pires, Rio Grande da Serra, Santo André e São Bernardo do Campo. Resultados. Verificou-se que das 58 escolas analisadas, 33 têm projetos de Educação Ambiental e destas, 14 escolas têm projetos que enfocam a Represa Billings. Entre as que têm projetos sobre o reservatório, apenas 9 estão atualmente em desenvolvimento. Cerca de $90 \%$ dos responsáveis pelos projetos não frequentaram curso de Educação Ambiental. A falta de capacitação pode ser considerada uma das principais causas para inexistência de projetos. Cerca de metade das escolas que têm projetos enfoca a "Lei de Proteção aos Mananciais" nas atividades. Foi detectada a existência de parcerias com empresas e fundações privadas, organizações não-governamentais e prefeituras locais. Conclusões. A Educação Ambiental não vem sendo adequadamente implementada nas escolas analisadas uma vez que muitas não desenvolvem projetos por falta de preparo técnico. Uma minoria aborda a degradação da Represa Billings em seus projetos. A ausência de capacitação e de acompanhamento permanente 
dos projetos, são fatores que dificultam a consolidação das propostas existentes.

Descritores: Educação Ambiental. Escola Pública. Represa Billings. 


\section{SUMMARY}

Roveratti DS. Diagnóstico de projetos de Educação Ambiental em escolas públicas das áreas de proteção de mananciais da Represa Billings [ Environmental education diagnosis at public schools in Billings Reservoir spring preservation areas]. São Paulo (BR); 1999.[Tese de Doutorado - Faculdade de Saúde Pública da Universidade de São Paulo].

Objective. The school teaching system is fundamental so as to carry out environmental education, and it must pro provide analysis of local environmental problems. This diagnosis was worked out aiming at the presentation of a whole view of environmental education at public schools nest to Billings Reservoir, verifying whether the recovery of the reservoir and the "Law for the Preservation of Springs" are focused. Methodology. 58 schools which lie in the cities of Diadema, Ribeirão Pires, Rio Grande da Serra, Santo André and São Bernardo do Campo spread out around Billings Reservoir were surveyed. Results. Out of the 58 schools surveyed, 33 bear projects for environmental education and out of this figure 14 schools focus towards Billings Reservoir. Among those which bear projects about the reservoir, only 9 keep current development. About $90 \%$ of the personnel in charge of the projects do not have a degree in environmental education. The lack background is one of the main reason why such projects are nonexistent. About $50 \%$ of the schools which bear such projects focus on the "Law for the Preservation of Springs" in their activities. A partnership with private companies and foundations as well as with local city halls and non-governmental organizations were also found. Conclusions. Environmental education have not been properly implemented at the schools surveyed as many do not develop projects towards environmental education. Degradation of Billings Reservoir is approached by a good minority in their projects. Lack of background and inexistence of continuous monitoring of the projects are factors whith make it difficult to carry out the existing proposals. 
Descriptors: Environmental education. Public Schools. Billings Reservoir. 


\section{ÍNDICE}

1- INTRODUÇÃO

1.1-Origens e breve histórico da Educação Ambiental

1.2- Evolução da Educação Ambiental no Brasil $\quad 12$

1.3- Objetivos da Educação Ambiental 17

1.4- Represa Billings e a região do $\mathrm{ABC} \quad 20$

1.5- As leis de proteção aos mananciais e a Represa Billings 24

2- OBJETIVOS 28

2.1- Objetivo Geral 28

2.2- Objetivos Especificos $\quad 28$

3- METODOLOGIA 29

3.1- Objeto de estudo 30

3.2- Levantamento de dados $\quad 30$

4- RESULTADOS

4.1- Panorama geral da Educação Ambiental nas escolas analisadas 33

Existência de projetos de Educação Ambiental 33

Número de estudantes atendidos nas escolas analisadas $\quad 34$

Distribuição das escolas por município $\quad 35$

Causas da inexistência de projetos nas escolas $\quad 36$

4.2- Perfil do coordenador do projeto na escola $\quad 37$

Cargo ou função do coordenador do projeto 37

Área de formação dos coordenadores $\quad 38$

Nível de escolaridade $\quad 39$

Capacitação em Educação Ambiental $\quad 39$

Conhecimento acerca dos documentos e textos oficiais 40

4.3- Características dos projetos $\quad 42$

Situação atual dos projetos $\quad 42$

$\begin{array}{lll}\text { Tipo de projeto } & \cdot & 44\end{array}$

Abrangência dos projetos $\quad 45$

$\begin{array}{ll}\text { Principais objetivos } & 46\end{array}$ 
Textos e documentos oficiais que subsidiam os projetos

Planejamento

$\begin{array}{ll}\text { Fonte motivadora } & 50\end{array}$

Parcerias 51

Custo anual do projeto $\quad 54$

Apoio financeiro $\quad 54$

Locais onde são desenvolvidas as atividades $\quad 55$

Duração das atividades $\quad 56$

Temas abordados nos projetos $\quad 57$

Atividades utilizadas $\quad 58$

Critérios de avaliação dos projetos e periodicidade $\quad 59$

Principais resultados 61

Principais dificuldades $\quad 62$

4.4- A Represa Billings no Contexto dos projetos $\quad 63$

Especificidade dos projetos em relação à Represa Billings 63

Descrição dos projetos $\quad 63$

Participação da comunidade $\quad 64$

Abordagem sobre a ocupação irregular das áreas de mananciais $\quad 65$

Conhecimento acerca da legislação referente à proteção de mananciais 66

Lei de proteção aos mananciais como subsídio para as atividades dos projetos $\quad 66$

5- DISCUSSÃO $\quad 68$

6- CONCLUSÕES

7- REFERÊNCIAS BIBLIOGRÁFICAS

ANEXOS

Anexo 1- Localização da região de estudo $\quad$ A 1

Anexo 2- Relação das escolas analisadas $\quad$ A 2

Anexo 3- Questionário $\quad$ A 5

Anexo 4- Roteiro de entrevista $\quad$ A 13

Anexo 5- Exemplo de projeto externo em parceria $\quad$ A 14

Anexo 6- Localização das escolas em relação à Represa Billings (mapa) $\quad$ A 18

Anexo 7- Situação atual dos projetos de Educação Ambiental (mapa) A 19

Anexo 8- Projetos de Educação Ambiental sobre a Billings, em desenvolvimento (mapa) A 20 


\section{LISTA DE TABELAS}

TABELA 1- Número de estudantes atendidos nas escolas analisadas, divididas por categoria com relação aos projetos de Educação Ambiental

TABELA 2- Distribuição das escolas por município de acordo com a existência de projetos de Educação Ambiental

TABELA 3- Conhecimento de textos e documentos oficiais pelos coordenadores dos projetos de Educação Ambiental que enfocam a Billings e os que não enfocam

TABELA 4- Situação atual dos projetos de Educação Ambiental nas escolas analisadas

TABELA 5- Textos e documentos oficiais que subsidiam os projetos que não enfocam a Represa Billings e os que enfocam

TABELA 6- Fonte motivadora dos projetos

TABELA 7- Existência de parcerias no desenvolvimento dos projetos

TABELA 8- Forma de parceria entre as escolas e instituições parceiras

TABELA 9- Situação atual dos projetos em parcerias

TABELA 10- Atividades e estratégias utilizadas por ordem de frequência

TABELA 11- Principais dificuldades encontradas para desenvolvimento dos projetos 


\section{LISTA DE FIGURAS}

FIGURA 1- Existência de projetos de EA nas escolas

FIGURA 2- Principais causas de inexistência de projetos nas escolas

FIGURA 3- Função exercida pelo coordenador do projeto na escola

FIGURA 4- Área de formação dos coordenadores

FIGURA 5- Nível de escolaridade do coordenador

FIGURA 6- Formação dos coordenadores em Educação Ambiental

FIGURA 7- Documentos e textos oficiais conhecidos pelos coordenadores

FIGURA 8- Distribuição dos projetos em desenvolvimento de acordo com o ano de início

FIGURA 9- Tipo de projeto de acordo com disciplinaridade

FIGURA 10- Abrangência dos projetos de Educação Ambiental que não enfocam a Represa Billings

FIGURA 11- Abrangência dos projetos de Educação Ambiental que enfocam a Represa Billings

FIGURA 12- Principal objetivo dos projetos analisados

FIGURA 13- Distribuição dos projetos de acordo com existência ou não de planejamento 
FIGURA 15- Custo anual do projeto

FIGURA 16- Tipo de apoio financeiro recebido

FIGURA 17- Locais onde são desenvolvidas as atividades do projeto

FIGURA 18- Duração das atividades do projeto

FIGURA 19- Principais temas abordados nos projetos

FIGURA 20- Formas de avaliação dos projetos

FIGURA 21- Periodicidade das avaliações dos projetos

FIGURA 22- Principais resultados obtidos nos projetos

FIGURA 23- Especificidade dos projetos em relação à Represa Billings

FIGURA 24- Caracterização dos projetos de acordo com a descrição

FIGURA 25- Participação da comunidade nos projetos

FIGURA 26- Abordagem pelos projetos da ocupação irregular das áreas de mananciais

FIGURA 27- Conhecimento dos responsáveis pelos projetos sobre a legislação de proteção aos mananciais

FIGURA 28- Abordagem da "Lei de Proteção aos Mananciais" pelos projetos que enfocam a Represa Billings 


\section{INTRODUÇÃO}

As alterações ambientais ocorridas principalmente nas últimas décadas, vêm alertando para a urgência de se modificar o rumo deste processo.

A Resolução das Nações Unidas de 1989, onde foi estabelecida a realização da Conferência do Meio Ambiente e Desenvolvimento Sustentável em 1992, reconheceu que "a causa maior da deterioração contínua do Meio Ambiente Global é o insustentável modelo de produção e consumo, particularmente nos países industrializados", e que "nos países em desenvolvimento a extrema pobreza e a degradação ambiental estão estreitamente relacionados" (SÃO PAULO 1997c).

Nos países em desenvolvimento, onde a degradação ambiental é agravada pelas condições econômicas e sociais precárias de grande parte da população, estas alterações tornam-se mais evidentes principalmente nas grandes concentrações urbanas.

Estas modificações profundas do meio ambiente que começam a ameaçar a própria sobrevivência humana, têm indicado a necessidade de se preparar os homens para viverem e se desenvolverem em harmonia com as leis naturais. Neste aspecto, é necessário que se incorpore nos processos educativos, a construção de uma nova racionalidade ambiental, sendo a Educação Ambiental um fator fundamental para a promoção de um desenvolvimento compativel com a utilização adequada dos recursos do ambiente.

A Educação Ambiental tem sido abordada em diversos eventos, encontros e conferências tanto no âmbito nacional como internacional, ao longo dos quais sua natureza, características, objetivos e estratégias vêm sendo construídos.

Educação Ambiental define-se como o "processo que consiste em proporcionar às pessoas uma compreensão crítica e social do meio ambiente, para elucidar valores e desenvolver atitudes que lhes permitam adotar uma posição crítica e participativa a respeito das 
questões relacionadas com a conservação e a adequada utilização dos recursos naturais, para a melhoria da qualidade de vida e a eliminação da pobreza extrema e do consumismo desenfreado" (MINISTÉRIO DO MEIO AMBIENTE 1999).

A Educação Ambiental, portanto, deve essencialmente levar o ser humano à uma relação mais equilibrada com o meio ambiente, objetivando utilizar os recursos naturais de forma a não comprometêlos no presente e no futuro.

Assim, a compreensão dos problemas contemporâneos é fundamental para que o homem possa adotar uma atitude crítica frente à sua responsabilidade em proteger o meio ambiente visando a recuperação, manutenção e melhoria da qualidade de vida.

As recomendações até o presente elaboradas e registradas em diversos documentos oficiais, reconhecem que para atingir seus objetivos, a Educação Ambiental deve procurar discutir e intervir na solução de problemas locais concretos, específicos do grupo social para o qual se dirigem as ações.

De acordo com JACOBI (1998),

"a postura de dependência e de desresponsabilização da população decorre principalmente da desinformação, da falta de consciência ambiental e de um déficit de práticas comunitárias baseadas na participação e no envolvimento dos cidadãos, que proponham uma nova cultura de direitos baseada na motivação e na co-participação da gestão ambiental das cidades".

Sendo assim, no que se refere ao exercício da Educação Ambiental, este deve estar relacionado à realidade do público que se pretende atingir, assumindo características metodológicas próprias que permitam enfocar o meio ambiente $e$ os problemas ambientais 
próximos ao indivíduo, de forma que este venha a participar efetivamente das soluções.

Ao mesmo tempo, apesar das divergências com relação ao aspecto metodológico, é consenso que o sistema escolar é um dos principais canais para a prática da Educação Ambiental.

A Conferência Internacional sobre Educação Ambiental realizada em Tbilisi, em 1977, já enfatizava o sistema escolar de ensino formal como protagonista das ações de Educação Ambiental.

A Agenda 21, elaborada durante a Conferência das Nações Unidas sobre Meio Ambiente e Desenvolvimento realizada no Rio de Janeiro em 1992, destaca no seu Capítulo 36, a importância dos programas de ensino incluírem uma análise critica dos problemas ambientais locais, visando a participação da sociedade nas suas soluções.

Em consonância com as recomendações e idéias mundiais, a importância da Educação Ambiental na solução dos problemas ambientais e a participação do ensino formal neste processo, tem sido reconhecida e estimulada no Brasil.

A Constituição da República Federativa do Brasil, promulgada em 1988, no Inciso VI, do Art.225, Cap.VI, determina que "cabe ao Poder Público promover a Educação Ambiental em todos os níveis de ensino e a conscientização pública para a preservação do meio ambiente".

O Ministério da Educação e Cultura, através da Portaria $n^{0} 678$, de 14 de maio de 1991, estabeleceu que a Educação Ambiental deveria estar inserida na educação escolar.

Em 1996, O Ministério da Educação e do Desporto, através dos Parâmetros Curriculares Nacionais e das Diretrizes Nacionais para o Ensino, incluiu a dimensão ambiental nos currículos da educação básica.

Tal preocupação do Governo Federal refletiu-se nas administrações públicas estaduais e algumas municipais que passaram a incluir a Educação Ambiental nos seus planos e programas. 
No Estado de São Paulo, a Constituição Estadual de 1989, Capítulo N, Seção I, Art.193, Parágrafo XV, destaca que é dever do Estado "promover a Educação Ambiental e a conscientização pública para a preservação, conservação e recuperação do meio ambiente".

Considera-se degradação ambiental as alterações e desequilíbrios provocados no meio ambiente, que prejudicam os seres vivos ou impedem os processos vitais ali existentes antes dessas alterações. $O$ termo recuperação ambiental, pressupõe o restabelecimento das características de um ambiente original que foi degradado, seja por ação antrópica ou por causas naturais. Já preservação é a ação de proteger contra a destruição e qualquer forma de dano ou degradação um ecossistema, uma área geográfica ou espécies animais e vegetais ameaçadas de extinção, adotando-se as medidas preventivas legalmente necessárias e as medidas de vigilância adequadas. Conservação é a utilização racional de um recurso qualquer, de modo a se obter um rendimento considerado bom, garantindo-se entretanto sua renovação ou sua auto-sustentação. Analogamente, conservação ambiental quer dizer o uso apropriado do meio ambiente dentro dos limites capazes de manter sua qualidade e seu equilíbrio em níveis aceitáveis. Proteção significa o ato de proteger; é a defesa daquele ou daquilo que é ameaçado; o termo "proteção" tem sido utilizado por vários especialistas para englobar os demais (preservação, conservação, recuperação), pois para eles, essas são formas de proteção (MINISTÉRIO DA EDUCAÇÃO E DO DESPORTO 1997c).

Ainda no que se refere ao Estado de São Paulo, a resolução conjunta da Secretaria do Meio Ambiente e da Secretaria da Educação, $\mathrm{n}^{\circ} 5$ de 1 de novembro de 1995, entre uma série de outras providências, criou um grupo de trabalho para coordenar a inclusão da Educação Ambiental nas escolas da rede estadual de ensino.

Desta forma, temos hoje projetos de Educação Ambiental sendo desenvolvidos num número significativo de escolas da rede pública estadual. 
Partindo destas premissas, deve-se esperar que os projetos desenvolvidos em escolas próximas às regiões de mananciais devem estar comprometidos com a abordagem relativa à necessidade de recuperação e proteção destas áreas.

Particularmente importante é a inclusão nestes projetos de uma análise e discussão da Lei Estadual $n^{\circ} 9.866 / 97$, promulgada em 28 de novembro de 1997, que traça "Diretrizes e Normas para Proteção e Recuperação das Bacias Hidrográficas dos Mananciais de Interesse Regional do Estado de São Paulo".

Como em outras regiões, o processo de ocupação na bacia da Represa Billings vem ocorrendo de forma muito intensiva na área da região metropolitana de São Paulo conhecida como $A B C$ paulista (constituída pelos municípios de Santo André, São Bernardo do Campo, São Caetano do Sul, Diadema, Ribeirão Pires, Mauá e Rio Grande da Serra), o que tem comprometido de forma alarmante a qualidade das águas deste reservatório de interesse para o abastecimento da Grande São Paulo. Pode-se dizer que entre os diversos problemas ambientais desta região, a recuperação e proteção da Represa Billings vem sendo encarada como prioridade pelos mais diversos setores.

A nova lei de proteção aos mananciais, já referida, pretende garantir uma preservação mais efetiva aos mananciais porém, para alcançar os resultados esperados, deve contar com a participação e envolvimento de todos os segmentos sociais, particularmente da sociedade civil.

Neste contexto verifica-se a importância da abordagem, entre outros temas, da lei de proteção aos mananciais nos projetos de Educação Ambiental desenvolvidos na região do $\mathrm{ABC}$.

Diante das considerações feitas até o momento, deve-se supor que os projetos de Educação Ambiental desenvolvidos nas escolas próximas à Represa Billings devem dar uma atenção especial à sua recuperação e proteção focalizando, também, a lei de proteção aos mananciais. 
O presente trabalho foi então conduzido, com o objetivo de caracterizar projetos de Educação Ambiental desenvolvidos em escolas da rede pública estadual localizadas nos municípios do $\mathrm{ABC}$, em áreas próximas à Represa Billings, procurando verificar, também, a abordagem que vem sendo dada sobre a lei de proteção aos mananciais.

Tal análise procurou fornecer um diagnóstico sobre a situação atual da Educação Ambiental nas escolas inseridas nas áreas de mananciais da Represa Billings, o qual procurou identificar direções a serem seguidas e caminhos a serem evitados, tendo em vista o aprimoramento de futuras ações.

O presente levantamento e análise das experiências desenvolvidas nestas escolas, poderá ser utilizado como referência na elaboração de propostas de Educação Ambiental para escolas localizadas em áreas de proteção de mananciais no Estado de São Paulo. 


\subsection{Origens e Breve Histórico da Educạ̧ão Ambiental}

De acordo com alguns autores o termo Educação Ambiental parece ter surgido originalmente dentro da Biologia ligado à estudos de Botânica e Ecologia (SATO 1994), porém durante certo tempo foi confundido com o ensino da Ecologia.

É um termo relativamente novo pois, conforme citado por PELICIONI (1998), a expressão Enviromental Education foi utilizada pela primeira vez somente em 1965, durante a Conferência em Educação realizada na Universidade de Keele, na Inglaterra.

Foi também no Reino Unido que constituiu-se, em 1968, o Conselho para Educação Ambiental, com o objetivo de coordenar as atividades de mais de 50 organizações voltadas para temas de educação e meio ambiente.

Embora possa ser considerado que o surgimento da Educação Ambiental tenha se dado na década de sessenta, foi somente na década de setenta que a Educação Ambiental adquiriu um caráter oficial passando a ser mencionada em diversos documentos de relevância internacional (GRÜN 1996).

Em 1970, a União Internacional para Conservação da Natureza e dos Recursos Naturais - IUCN, definiu o termo Educação Ambiental como sendo o "processo de reconhecimento de valores e de esclarecimento de conceitos que permitam o desenvolvimento de habilidades e atitudes necessárias para entender e apreciar as inter-relações entre o homem, sua cultura e seu ambiente biofísico circunjacente" (DIAS 1994 ). Neste mesmo ano, durante a Conferência de Educação Ambiental realizada em Nevada sob o patrocínio da Organização das Nações Unidas para a Educação, Ciência e Cultura - UNESCO, o termo Educação Ambiental também foi oficialmente reconhecido e sua prática foi recomendada (SATO 1994 ).

Em junho de 1972 foi realizado em Estocolmo, na Suécia, a Conferência das Nações Unidas sobre o Ambiente Humano - 
"Conferência de Estocolmo", da qual participaram 113 países incluindo o Brasil e onde foi elaborada uma recomendação para a criação de um Programa Internacional de Educação Ambiental - PIEA visando combater a crise ambiental do mundo (DIAS 1994; VIANNA e col., 1996). Seguindo esta recomendação, a UNESCO e o Programa das Nações Unidas para o Meio Ambiente - PNUMA, criaram em 1975 - PIEA, cujos princípios e orientação formulados por especialistas de 65 países foram lançados no mesmo ano pela "Carta de Belgrado" (GRÜN 1996; SATO 1994).

Ainda em cumprimento às recomendações da Conferência de Estocolmo, a UNESCO em cooperação com o PNUMA, realizaram em 1977 em Tbilisi na Geórgia, a I Conferência Intergovernamental sobre Educação Ambiental - "Conferência de Tbilisi" (GRÜN 1996; SATO 1994; SÃO PAULO 1997c), a qual é considerada um marco para a Educação Ambiental no mundo pois nesta reunião foram definidas as finalidades, características, estratégias e princípios da Educação Ambiental. Estabeleceu-se também a definição de "Educação Ambiental" ainda hoje adotada pelo Brasil e por outros países membros da Organização das Nações Unidas- ONU: “dimensão dada ao conteúdo e à prática da educação, orientada para a resolução dos problemas concretos do meio ambiente através do enfoque interdisciplinar e de uma participação ativa e responsável de cada indivíduo e da coletividade".

Em 1987, a UNESCO e o PNUMA promoveram em Moscou, na Rússia, o Congresso Internacional sobre Educação e Formação Ambientais, com a participação de mais de 300 especialistas oriundos de 100 países e durante o qual foram analisadas as conquistas e dificuldades da Educação Ambiental no mundo, além de terem sido traçadas as metas e recomendações para a década de noventa. Vale salientar que a participação do Brasil foi ainda inexpressiva. (GUIMARÃES 1995). 
No ano seguinte, 1988, a UNESCO e o PNUMA promoveram em Buenos Aires, na Argentina, o Seminário Latino-Americano de Educação Ambiental onde foram estabelecidas recomendações específicas para os países latino-americanos levando-se em consideração o modelo de desenvolvimento vigente nestes países. De acordo com DIAS (1994) podem ser destacadas as seguintes recomendações deste encontro:

- a Educação Ambiental deve fazer parte da política ambiental dos países;

- a Educação Ambiental deve adaptar-se às características culturais especificas das populações envolvidas no processo educativo;

- a Educação Ambiental deve ter presente o papel que a mulher desempenha na família, na sociedade e no desenvolvimento;

- a Educação Ambiental deve promover a reformulação da educação formal e não-formal para uma concepção ambientalista;

- a Educação Ambiental deve considerar o contexto de subdesenvolvimento que vivem os países da América do Sul e se transformar num instrumento idôneo para a integração e o apoio mútuo entre as nações da região;

- a Educação Ambiental deve salientar a necessidade de criação de um novo estilo de desenvolvimento que inclua crescimento econômico, igualdade social e conservação dos recursos naturais, capaz de propiciar relações mais humanas, fraternas e justas entre os homens, e destes com o seu entorno natural, atingindo níveis crescentes de qualidade de vida. 
As recomendações da Conferência de Tbilisi foram novamente reforçadas durante a Conferência das Nações Unidas sobre Meio Ambiente e Desenvolvimento - a Rio/92 -, realizada no Brasil na cidade do Rio de Janeiro em junho de 1992. Durante a Rio/92, vários documentos foram elaborados. Entre eles, a Agenda 21, aprovada por 170 países, apresenta um plano de ação para o desenvolvimento sustentável a ser adotado pelos países signatários, entre os quais o Brasil. A Agenda 21 constituiu-se em um plano de ação para se alcançar o desenvolvimento sustentável à médio e longo prazos, prevendo uma nova perspectiva de cooperação internacional para solução dos problemas ambientais e vinculou a Educação Ambiental à sustentabilidade (SÃO PAULO 1997a; SÃO PAULO 1997c; VIANNA e col., 1996).

Durante o Fórum Global, realizado no âmbito da Rio/92, foi celebrado o Tratado de Educação Ambiental para Sociedades Sustentáveis e Responsabilidade Global, documento de caráter não oficial elaborado por diversas organizações da sociedade civil, onde se reconheceu que a "Educação Ambiental para uma sustentabilidade eqüitativa é um processo de aprendizagem permanente baseado no respeito a todas as formas de vida" (SÃO PAULO 1997c; VIANNA e col., 1996; VIEZZER e OVALLES 1995).

$\mathrm{Na}$ Rio/92 foi dado um destaque para a necessidade de reorientar a educação para o desenvolvimento sustentável, tendo em vista o "analfabetismo ambiental" dominante no planeta e foi também enunciada a definição de Educação Ambiental segundo a qual a "Educação Ambiental é o processo que deve permitir a compreensão da natureza complexa do meio ambiente $e$ interpretar a interdependência entre os diversos elementos que conformam o ambiente com vista a utilizar racionalmente os recursos no presente e no futuro". (DIAS 1994; SÃO PAULO 1998b).

Em dezembro de 1997, foi realizada em Tessalonique, na Grécia, a Conferência Internacional sobre Meio Ambiente e Sociedade: 
Educação e Conscientização Pública para a Sustentabilidade, que resultou na Declaração de Tessalonique. Este documento reafirmou várias das orientações dos encontros internacionais anteriores e destacou questões fundamentais, entre as quais a necessidade de formação de professores, a carência de materiais didáticos, a falta de políticas nacionais e de recursos destinados à sua execução (MANZOCHI 1998). 


\subsection{Evolução da Educação Ambiental no Brasil}

No âmbito nacional, o papel da Educação Ambiental na solução dos problemas ambientais tem sido reconhecido principalmente a partir da década de oitenta.

Em 1981, a Lei $\mathrm{n}^{\circ}$ 6.938/81, regulamentada pelo Decreto $\mathrm{n}^{\circ}$ 88.351/83; faz a primeira referência legal sobre a Educação Ambiental. Esta lei do Governo Federal dispõe sobre os fins, mecanismos de formulação e aplicação da Política Nacional do Meio Ambiente, cria o Conselho Nacional do Meio Ambiente - CONAMA para atuar no estabelecimento de regulamentos e normas da política ambiental nacional e também contempla a Educação Ambiental através do seu décimo princípio o qual dispõe que a Educação Ambiental deve ser oferecida a todos os níveis do ensino, inclusive para a comunidade, objetivando capacitá-la para participação ativa na defesa do meio ambiente (MINISTÉRIO DA EDUCAÇÃO E DO DESPORTO 1997a).

Em 1987, o então Conselho Federal da Educação - CFE, encarregado da formulação da política educacional, emitiu o Parecer CFE 226/87 onde é enfatizado que a Educação Ambiental deve ser iniciada "a partir da escola, numa abordagem interdisciplinar, levando a população a um posicionamento em relação a fenômenos ou circunstâncias do ambiente". O mesmo parecer também recomenda a criação de Centros de Educação Ambiental no país para atuarem como pólos de disseminação (MINISTÉRIO DA EDUCAÇÃO E DO DESPORTO 1997a).

Diante do panorama mundial e coerente com os compromissos internacionais assumidos pelo Brasil, a Constituição da República Federativa do Brasil promulgada em 1988, definiu a promoção da Educação Ambiental como uma responsabilidade do Poder. Público estabelecendo em seu Art.225 que "todos têm o direito ao Meio Ambiente ecologicamente equilibrado" e que de acordo com o parágrafo $1^{\circ}$ deste artigo, esse direito deverá ser assegurado através da 
promoção da Educação Ambiental em todos os níveis de ensino e a conscientização pública para a preservação do meio ambiente (MINISTÉRIO DA EDUCAÇÃO E DO DESPORTO 1997a; 1997b).

Paralelamente aos dispositivos legais, iniciaram-se no final da década de oitenta e início dos anos noventa, uma série de projetos, encontros, seminários e outras atividades enfocando a Educação Ambiental, desenvolvidas e patrocinadas por diversas instituições do poder público e da sociedade civil.

Através da Portaria n ${ }^{\circ} 678$ de 14 de maio de 1991 , o Ministério da Educação e do Desporto - MEC, determinou que a educação escolar deve contemplar a Educação Ambiental. O MEC apoiou também, em 1992, a instalação de vários Centros de Educação Ambiental no país (MINISTÉRIO DA EDUCAÇÃO E DO DESPORTO 1997a).

Em dezembro de 1994 a Presidência da República aproṿou a “exposição de motivos” encaminhada pelo MEC e Ministério do Meio Ambiente, Recursos Hídricos e Amazônia Legal - MMA, com apoio do Ministério da Cultura- MinC e Ministério da Ciência e TecnologiaMCT, a qual estabeleceu diretrizes para implantação de um Programa Nacional de Educação Ambiental - PRONEA. Tal programa teve suas diretrizes e estratégias estabelecidas por uma Câmara Técnica Temporária de Educação Ambiental instalada em 1996 pelo CONAMA. Finalmente em junho de 1997, o MEC publicou o PRONEA visando cumprir os dispositivos constitucionais relativos à Educação Ambiental bem como contemplar os compromissos internacionais assumidos pelo país nesta área (MINISTÉRIO DA EDUCAÇÃO E DO DESPORTO 1997b).

Ainda em 1997, o Ministério do Meio Ambiente e o Ministério da Educação e Cultura, promoveram em Brasília a "I Conferência Nacional de Educação Ambiental", buscando avaliar os avanços da Educação Ambiental no país, após 20 anos da Conferência de Tbilisi. Tal evento congregou um grande número de profissionais provenientes de vários Estados, possibilitando uma ampla discussão sobre os 
diversos aspectos da Educação Ambiental. Durante o evento o Ministério do Meio Ambiente divulgou o relatório do "Levantamento Nacional de Projetos de Educação Ambiental", publicação que objetivou, analisar a situação da Educação Ambiental no país (MINISTÉRIO DO MEIO AMBIENTE 1997). A relevância deste evento no plano nacional, possibilitou a elaboração da Declaração de Brasília para a Educação Ambiental, apresentada em dezembro de 1997 na Conferência Internacional sobre Meio Ambiente e Sociedade: Educação e Conscientização Pública para a Sustentabilidade, realizada em Tessalonique, na Grécia (MINISTÉRIO DO MEIO AMBIENTE 1999).

Em 27 de abril de 1999, foi sancionada pela Presidência da República, a Lei $\mathrm{n}^{\circ}$ 9.795/99 que instituiu a Política Nacional de Educação Ambiental e estabeleceu os princípios norteadores para a Educação Ambiental no país. $\mathrm{O}$ Art. $2^{\circ}$ da referida lei declara que "a educação ambiental é um componente essencial e permanente da educação nacional, devendo estar presente, de forma articulada, em todos os níveis e modalidades do processo educativo, em caráter formal e não formal"

No que se refere especificamente ao Estado de São Paulo vale mencionar a criação, em 1989, da Coordenadoria de Educação Ambiental- CEAM, vinculada à Secretaria do Meio Ambiente- SMA. Em junho de 1995, a resolução SMA n²6 criou o Programa Estadual de Educação Ambiental que objetivou estabelecer os pressupostos, objetivos e bases para a Educação Ambiental no Estado de São Paulo. Em novembro de 1995 , através da resolução conjunta $\mathrm{n}^{\circ} 5$, entre a Secretaria do Meio Ambiente e a Secretaria da Educação, criou-se um grupo de trabalho para coordenar a introdução da Educação Ambiental nas escolas da rede pública estadual. Finalmente, em janeiro de 1998, - Governo do Estado instituiu o Programa Núcleos Regionais de Educação Ambiental através do decreto 42.798, que implantou até o presente cerca de quarenta Núcleos espalhados por diversas regiões do 
estado, os quais tem como objetivo apoiar e desenvolver projetos e ações de Educação Ambiental nas suas regiões de abrangência (SÃO PAULO 1998b).

Em outubro de 1993 foi criada na cidade de São Paulo, por meio da Lei 11.426, a Secretaria Municipal do Verde e do Meio AmbienteSVMA, com o objetivo de planejar, ordenar e coordenar as atividades de defesa do meio ambiente na capital paulista (SÃO PAULO 1996a). A estrutura organizacional da SVMA é atualmente composta por três Departamentos, entre eles o Departamento de Educação Ambiental e Planejamento que entre outras atribuições deve coordenar e executar programas e ações educativas orientados para promover a participação da sociedade na melhoria da qualidade ambiental e, também, atuar como apoio técnico aos programas de Educação Ambiental em escolas de $1^{\circ}$ e $2^{\circ}$ graus desenvolvidos pela Secretaria Municipal de Educação ( PHILIPPI JR e col. 1999). Como parte destas atribuições, a SVMA vêm desenvolvendo uma série de atividades, como por exemplo, a realização através de uma parceria com o Instituto Brasil de Educação Ambiental e outras entidades, do "Curso de Formação de Educadores Ambientais", ocorrido no primeiro semestre de 1998 em área da Represa Billings, na zona sul de São Paulo (TAKAHASHI 1998).

Outros municípios, como os localizados na área de estudo deste trabalho, também criaram estruturas próprias para tratar especificamente das questões ambientais, as quais têm colocado as ações de Educação Ambiental dentro de suas atribuições, como por exemplo, o Departamento de Gestão Ambiental de Santo André, a Secretaria de Planejamento e Meio Ambiente da Prefeitura Municipal de Mauá, os Departamentos de Meio Ambiente dos municípios de Diadema, de São Bernardo do Campo e de Ribeirão Pires.

Devem ser mencionadas, também, a atuação de diversas "organizações não-governamentais"- ONGs, que ao longo de todo território nacional vêm desenvolvendo importantes trabalhos relacịonados à Educação Ambiental. 
Especificamente na área da Represa Billings, o Instituto Ecoar Para a Cidadania- ECOAR vem desenvolvendo o projeto de Educação Ambiental "Billings Margem Verde", financiado pelo Fundo Estadual de Recursos Hídricos- FEHIDRO. Tal projeto abrange seis escolas públicas localizadas no distrito de Pedreira e Grajaú, na zona sul de São Paulo*.

* comunicação pessoal obtida junto ao ECOAR, em Abril de 2000. 


\subsection{Objetivos da Educação Ambiental}

Um dos objetivos básicos da Educação Ambiental é ampliar a consciência ambiental dos indivíduos para produzir uma mudança nas relações com o meio ambiente.

Para FREIRE (1979b), "conscientizar-se é testar o ambiente, desvendar a realidade, analisar o objeto penetrando na essência do fenômeno". Trata-se de um conhecimento ativo, comprometido com a transformação da realidade ( FREIRE 1979a ). Portanto, a "conscientização", para o autor, rejeita qualquer hipótese de uma educação que tenha de um lado, um transmissor ativo e de outro, um receptor passivo (BECKER 1997 ).

Um aspecto a ser considerado é a educação diante da questão ambiental.

A educação tem como papel fundamental a formação de consciências individuais e coletivas; é um ato de conhecimento, uma aproximação crítica da realidade.

Educação "diz respeito ao caráter formativo do ser humano, promovendo uma postura interna de reverência pela vida, formando pessoas amorosas, ressaltando a importância do auto-conhecimento, da inclusão de outros seres nos processos individuais e da expansão para o coletivo" (HÖEFFEL e col. 1998).

Deve-se reconhecer que a área do meio ambiente se encontra profundamente ligada a conflitos de interesses econômico-sociais.

A Educação Ambiental, portanto, deve tratar de uma consciência que se sensibiliza com os problemas não apenas do ambiente, mas também e principalmente de problemas sociais e econômicos.

Desta forma, podemos dizer que a Educação Ambiental deve criar as bases que permitam uma compreensão mais ampla da realidade, incentivando ao exercício da cidadania o que implica na participação dos indivíduos para solução dos problemas ambientais e sociais relacionados. 
Portanto, é necessário rever as práticas educacionais tradicionais discutindo o papel da educação na busca de respostas para as questões básicas da sociedade.

Segundo FREIRE ( 1979a, 1979c ), a educação problematizadora ou crítica, se realiza no diálogo e é constituída de uma visão histórica do homem e de uma visão evolutiva da realidade.

Ao contrário da educação tradicional ou bancária que procura saturar o educando de conteúdos que sua inteligência não apreende porque não tem condições de reelaborá-los e, também, porque não dizem respeito ao seu mundo, a educação problematizadora, instaurando o diálogo, proporciona as condições prévias para a educação que liberta. Na educação crítica, o educador deve proporcionar ao educando as condições para a superação do conhecimento superficial e enganador, pelo verdadeiro conhecimento: o conhecimento que atinge a razão . O homem passa a se ver não mais como objeto da realidade, mas como o sujeito que pode transformá-la.

Ainda de acordo com Paulo Freire, a conquista da própria identidade e da liberdade, é possível ao ser humano graças à ação no meio e à tomada de consciência dos sistemas de significação nos quais essa ação se insere. É graças à ação, que o homem pode transformar a si mesmo e transformar o mundo em que vive (BECKER 1997 ).

A Educação Ambiental deverá, portanto, construir instrumentos para estimular e realimentar o processo contínuo da "reflexão-ação" e não apenas ficar centrada na transmissão de informações sobre as questões ambientais.

Deverá estar presente nas diferentes modalidades do saber e do agir, suscitando a atitude crítica e despertando a capacidade criadora que possibilita o descobrimento de novos métodos e de novas soluções (SÃO PAULO 1998b). Exercida de acordo com a visão problematizadora de Paulo Freire, a Educação Ambiental torna-se um instrumento fundamental de ampliação da cidadania e de transformação da realidade. 
No âmbito nacional, um grande número de projetos de Educação Ambiental são direcionados a estudantes da rede formal de ensino e devido à ausência de uma metodologia própria para a Educação Ambiental, a metodologia tradicional para transmissão de conhecimentos utilizada nas escolas, tem sido transferida para tais projetos. Desta forma, nem sempre estes projetos conseguem atingir os objetivos fundamentais da Educação Ambiental.

O estabelecimento de critérios metodológicos próprios para a Educação Ambiental, que levem em consideração o papel de uma educação que inclua a consciência ambiental, sem dúvida é um dos grandes desafios a ser vencido.

Tal fato tem levado diversos documentos a enfatizarem nos seus textos a necessidade de se efetuarem pesquisas sobre metodologias, materiais educativos e outros instrumentos para a prática da Educação Ambiental.

No Brasil, no que se refere às diretrizes para a implantação da Política Nacional de Educação Ambiental, foram propostas uma série de ações necessárias para implementar o desenvolvimento de instrumentos e metodologias específicas para a Educação Ambiental. Tais propostas recomendam desde a elaboração e difusão de materiais educativos até a promoção e apoio à pesquisas na área (MINISTÉRIO DO MEIO AMBIENTE 1999). 


\subsection{Represa Billings e a Região do ABC}

A Bacia do Reservatório Billings, juntamente com as bacias do Rio Tietê Alto-Cabeceiras, do Rio Tietê Alto-Zona Metropolitana, do Rio Cotia e do Reservatório do Guarapiranga, compõem o complexo sistema de abastecimento e drenagem da Região Metropolitana de São Paulo. É composta basicamente pelo Reservatório ou Represa Billings além dos rios Grande, Pequeno, Bororé e Taquacetuba e outros reservatórios menores (CETESB 1998). Fazem parte da Bacia da Billings, a porção sul dos municípios da São Paulo, Diadema, São Bernardo do Campo e Santo André, grande parte de Ribeirão Pires e integralmente o município de Rio Grande da Serra (SÃO PAULO 1997b). A maior parte do Reservatório Billings está, assim, inserida na área da região metropolitana de São Paulo conhecida como $\mathrm{ABC}$ paulista (Anexo 1).

Como já mencionado anteriormente, o $\mathrm{ABC}$ paulista é composto por 7 municípios: Santo André, São Bernardo do Campo, São Caetano do Sul, Diadema, Mauá, Ribeirão Pires e Rio Grande da Serra.

A região onde fica localizada a cidade de São Paulo e os municípios do $\mathrm{ABC}$, foi considerada por muitos anos como rica em recursos hidricos devido a presença de rios importantes como o Rio Tietê e o Rio Tamanduateí. Porém, o processo desordenado de urbanização ocorrido ao longo de décadas, acabaram por gerar escassez e má qualidade das águas, tornando esta região uma das mais problemáticas do país neste sentido (SOBRAL 1996).

A crescente demanda de água que vem ocorrendo na região metropolitana de São Paulo, tem enfatizado o importante papel da Represa Billings como um reservatório potencial para o abastecimento da Grande São Paulo.

É notório que nos últimos anos todo o Complexo Billings tem passado por um processo intenso de degradação, principalmente pela ocupação desordenada de toda a bacia (SEMASA 1991a). 
Tal situação tem levado a inúmeras iniciativas que visam a recuperação da qualidade da água deste reservatório.

Dentre uma série de medidas técnicas que vem sendo implementadas por setores do poder público estadual e municipal, é consenso que tal recuperação só será efetiva com a participação da sociedade civil, principalmente das populações de entorno (AGUIAR 1994; LOPES 1993).

Neste contexto, a necessidade de se elaborar programas de Educação Ambiental aplicados às comunidades das cidades vizinhas à Billings, tem se mostrado um aspecto muito importante a ser considerado dentro do conjunto de ações de controle da degradação que afeta o reservatório (SÃO PAULO 1990).

Particularmente no que se refere às cidades do $\mathrm{ABC}$ paulista, a Represa Billings apresenta um aspecto especial para seus moradores devido ao seu potencial de lazer. Nestas cidades, vivem mais de 2 milhões de pessoas, o que representa $13,3 \%$ da população da Região Metropolitana de São Paulo. Cerca de 256 mil destes habitantes, ou seja, $30 \%$ da população total, reside em Área de Proteção aos Mananciais na Região Metropolitana (SÃO PAULO 1997b).

Pode-se dizer que dificilmente algum dos moradores desta região não tenha em dado momento de sua vida passeado nas margens da Represa Billings ou pescado em suas águas. Este aspecto reforça a contribuição que os programas de Educação Ambiental podem trazer para o processo de recuperação e proteção do reservatório uma vez que os moradores do $\mathrm{ABC}$ têm mais do que um vínculo meramente material ou racional com o reservatório.

Este vínculo afetivo é fundamental para a Educação Ambiental pois tendemos a querer "conservar" aquilo de que gọstamos.

Conforme fói colocado por Ribeiro (1998) citado por SANTOS (1999, p.76), primeiro deve vir a admiração pelo o que nos rodeia, o que leva a um envolvimento mais profundo que é o gostar ou mesmo amar; esse envolvimento afetivo determina o respeito por aquilo que 
amamos ou admiramos, surgindo daí a necessidade de conservação do objeto deste afeto.

Desta forma, podemos dizer que o afeto sensibiliza os indivíduos para o valor daquilo que o cerca, o que acaba por gerar uma consciência da sua importância. Portanto, não há uma conscientização "de fato", se não houver primeiramente uma sensibilização, a qual está profundamente relacionada aos aspectos afetivos.

Atualmente a Represa Billings ocupa uma área inundada de $127 \mathrm{Km}^{2}$ com um volume de 1.200 milhões de metros cúbicos (SÃO PAULO 1997b).

Foi construída originalmente-com a finalidade de gerar energia através do sistema Henry Borden. Tal construção, autorizada pelo Decreto-Lei 16.844 de 16 de abril de 1925, deu-se entre os anos de 1927 e 1937, seguindo projeto idealizado pelo engenheiro Asa Kenney Billings, o qual represou os rios Grande, Pequeno, Capivari, Pedra Branca, Taquacetuba, Alvarengas, Bororé e Cocaia através da construção da Estação Elevatória de Pedreira, que represou o Rio Jurubatuba, também conhecido como Rio Grande. Com o represamento, o Rio Grande praticamente desapareceu dando lugar ao canal de Pinheiros ou Rio Pinheiros, quando teve seu leito retificado a partir da foz, para retornar as águas poluídas do Tietê para a Billings (CASTILHO 1998; SÃO PAULO 1997b).

A construção da represa foi financiada pela empresa canadense Light, interessada na geração de energia. O projeto objetivou lançar as águas da represa serra abaixo através da cachoeira de Água Fria, caindo em Cubatão de uma altura de $740 \mathrm{~m}$, para movimentar as turbinas na usina hidrelétrica Henry Borden (SÃO PAULO 1997b).

Até 1949 a represa era conhecida como Reservatório do Alto da Serra quando então passou a se denominar Represa Billings numa homenagem feita pela Light ao seu idealizador (CASTILHO 1998).

Durante o período de construção da represa várias vilas foram sendo formadas na região do $A B C$ uma vez que o empreendimento chegou a 
empregar 6.000 trabalhadores e estimular a instalação de várias fábricas (CASTILHO 1998). Data dessa época o profundo envolvimento da comunidade local com o reservatório.

Pode-se dizer que a degradação da Represa Billings iniciou-se em 1950 quando as águas poluídas do Rio Tietê passaram a ser ali lançadas através do Rio Pinheiros que também recebia esgoto da cidade de São Paulo (SÃO PAULO 1996b; SÃO PAULO 1997b).

Nesta mesma época chegaram na região do $\mathrm{ABC}$ as indústrias automobilísticas que incentivaram também a formação de um grande número de vilas entre as décadas de 50 e 60 . À medida que os terrenos próximos das indústrias foram ficando mais caros, a população mais pobre passou a ocupar as áreas próximas às margens da represa que na época não apresentava restrições com relação ao uso e ocupação do solo (CASTILHO 1998).

Desta maneira uma grande parte das margens da Billings foi ocupada irregularmente e os esgotos ali gerados terminaram por ser lançados diretamente nas suas águas.

Foi somente no início dos anos setenta que a preocupação com o aumento da poluição da Represa Billings levou o Governo Federal a determinar que o Governo de São Paulo realizasse estudos para estabelecer medidas a fim de reduzir esta poluição. Essa determinação constituiu a origem da regra operacional adotada a partir de 6 de fevereiro de 1975 e aplicada até o ano de 1977, a qual estabeleceu alguns parâmetros de modo a manter um certo grau de qualidade nas águas da represa (SÃO PAULO 1997b). 


\subsection{As Leis de Proteção aos Mananciais e a Represa Billings}

Os estudos iniciados pelo Governo do Estado de São Paulo, aliados à elaboração do Plano Metropolitano de Desenvolvimento Integrado que orientou a política a ser seguida na década de setenta para o desenvolvimento da Região Metropolitana de São Paulo, deram origem a três instrumentos legais que contemplaram as áreas de mananciais: a Lei $\mathrm{n}^{\circ}$ 898, de 18 de dezembro de 1975; a Lei ${ }^{\circ} 1.172$, de 17 de novembro de 1976 e o Decreto $\mathrm{n}^{\circ}$ 9.714, de 19 de abril de 1977. As leis delimitam as áreas a serem protegidas e estabelecem parâmetros de uso e ocupação do solo das bacias; o decreto estabelece as competências dos vários órgãos envolvidos, além das sanções e procedimentos para aprovação (SÃO PAULO 1984; SEMASA 1991b).

Entre as inovações contidas na Lei $\mathrm{n}^{\circ} \mathbf{8 9 8}$, está a inclusão de um artigo de caráter preventivo à legislação, para conter a deterioração do meio ambiente; além do fato que prioriza a Região da Grande São Paulo como área mais crítica do Estado. Foi elaborada, por ser um complemento indispensável à legislação federal e estadual vigente, de modo a permitir a atuação preventiva no controle da poluição e preservação dos mananciais (SÃO PAULO 1984; SEMASA 1991 b).

No que se refere especificamente à Represa Billings, a Lei $\mathrm{n}^{\circ} 898$ declara o reservatório como área de proteção e portanto, sujeita às determinações legais relativas à restrições quanto ao seu uso e ocupação (SÃO PAULO 1984).

A Lei $\mathrm{n}^{\circ} 1.172$ criou as faixas e critérios para ocupar as margens da represa (SÃO PAULO 1984).

A legislação mencionada, ao disciplinar a ocupação do solo, estabeleceu categorias de áreas de proteção para as quais foram definidos os usos permitidos bem como critérios para implantação dos sistemas de coleta de resíduos sólidos e esgoto, disposição dos resíduos e sistemas de abastecimento de água (SÃO PAULO 1984). 
Apesar da legislação, o processo de ocupação na bacia da Billings continuou a acontecer de forma intensiva e irregular. Os assentamentos continuaram a ocorrer em locais cada vez mais próximos à represa (MORENO 1994; SÃO PAULO 1997b).

Atualmente são observadas nas margens da Billings várias ocupações clandestinas, favelas, loteamentos populares e lixões.

A ocupação é feita principalmente por população de baixa renda que estabelece suas moradias ao lado de chácaras de recreio de classe média e áreas destinadas ao lazer. Nestas áreas prevalece uma deficiência dos serviços essenciais como saúde, educação, transporte e saneamento básico. O lançamento de esgoto sem tratamento em córregos e rios e a inexistência de áreas destinadas para a disposição de resíduos sólidos são os fatores que mais afetam a qualidade da água do reservatório.

No que se refere ao esforço da legislação em proteger a Represa Billings cabe mencionar a Resolução Conjunta $\mathrm{n}^{\circ} 3$ da Secretaria Estadual do Meio Ambiente e da Secretaria Estadual de Energia e Saneamento, de 1992, que suspendeu definitivamente o bombeamento das águas do Rio Pinheiros para o reservatório Billings, com exceções de situações de emergência (SÃO PAULO 1997b).

As medidas técnicas e operacionais relativas ao Sistema Billings podem se mostrar ineficientes se não for impedida a degradação da qualidade da água da represa pelo crescimento da ocupação urbana, associada a programas específicos de melhoria da qualidade ambiental conforme salienta a importância da Lei de Proteção de Mananciais.

Considerando que a legislação existente não conseguiu impedir a ocupação das áreas de mananciais da Grande São Paulo, após discussões com a sociedade, foi apresentado à Assembléia Legislativa o Projeto de Lei denominado "Lei de Proteção e Recuperação dos Mananciais", aprovado e assinado em 28 de novembro de 1997 como Lei estadual $n^{\circ}$ 9.866/97 (SÃO PAULO 1998a). 
A "Lei de Proteção das Bacias Hidrográficas dos Mananciais de Interesse Regional do Estado de São Paulo"- Lei n 9.866/97 - revê a antiga legislação e apresenta reformulações que visam recuperar e preservar os mananciais através de novos instrumentos legais.

Essa lei alterou as características da lei vigente na época, basicamente pelos seguintes elementos que contém: adoção de Bacia Hidrográfica como unidade de planejamento e gestão; vinculação ao Sistema Estadual de Recursos Hídricos; criação de Áreas de Proteção e Recuperação dos Mananciais - APRMs e Áreas de Intervenção, classificadas em Áreas de Restrição à Ocupação, Áreas de Ocupação Dirigida e Áreas de Recuperação Ambiental; definição dos instrumentos de Planejamento e Gestão das bacias e criação do Sistema de Gestão das APRMs (SÃO PAULO 1998a).

Desta forma, a Lei $9.866 / 97$ estabelece os preceitos que norteiam a implantação do sistema de disposição e o tratamento de resíduos sólidos e efluentes líquidos, as penalidade às infrações a ela e às leis específicas e, também, as formas de gestão. Aponta também aspectos a serem considerados por leis específicas (SÃO PAULO 1998a).

As leis especificas deverão estabelecer as diretrizes para o controle das situações locais (como por exemplo criar uma APRM); estabelecer Áreas de Intervenção e definir diretrizes e normas no âmbito regional para proteção e recuperação dos mananciais (SÃO PAULO 1998a).

Com relação à Represa Billings, a nova lei propõe um plano emergencial de recuperação que resolva, entre várias questões, o problema dos esgotos, com soluções técnicas que a lei ambiental não previa.

Outro aspecto importante é que a Lei $n^{\circ} 9.866 / 97$ faz menção especifica à Educação Ambiental. No Capítulo VI relativo ao Plano de Desenvolvimento e Proteção Ambiental, o Artigo 31 estabelece: “Para cada APRM, será elaborado um Plano de Desenvolvimento e Proteção Ambiental - PDPA, contendo:.... VIII - Programa Integrado de Educação Ambiental..." (SÃO PAULO 1998a). 
Fica caracterizada assim na nova lei, a necessidade de se implementar programas de Educação Ambiental nas áreas de mananciais que abranjam todos os setores inclusive as escolas, as quais foram objeto do presente estudo. 


\section{OBJETIVOS}

\subsection{Objetivo Geral}

Contribuir para a obtenção de um panorama da situação atual da Educação Ambiental nas escolas públicas localizadas em áreas de proteção de mananciais da Represa Billings, fornecendo subsídios para o aprimoramento de programas de Educação Ambiental desenvolvidos na região analisada.

\subsection{Objetivos Específicos}

- Caracterizar projetos de Educação Ambiental desenvolvidos em escolas da rede pública estadual localizadas em áreas próximas à Represa Billings, no ABC paulista;

- Verificar se a problemática da degradação da Represa Billings vem sendo abordada nestes projetos;

- Verificar se a Lei Estadual $\mathrm{n}^{\circ} 9.866 / 97$ sobre a nova Política de Mananciais definida como "Lei de Proteção aos Mananciais", tem subsidiado as atividades de Educação Ambiental dos projetos analisados;

- Fornecer algumas referências para a elaboração de propostas de Educação Ambiental para escolas inseridas em áreas de proteção de mananciais do Estado de São Paulo;

- Possibilitar que os dados levantados com este diagnóstico, sirvam de referência para outros estudos mais aprofundados. 


\section{METODOLOGIA}

De acordo com as modalidades de teses reconhecidas pela Faculdade de Saúde Pública da Universidade de São Paulo-FSP/USP, o presente trabalho pode ser considerado um estudo descritivo devido ao enfoque predominante do seu delineamento. São classificadas como estudo descritivo "as teses de pesquisa exploratória, ou seja, aquelas que podem ou não apresentar hipóteses claramente definidas e cujo objetivo consiste em caracterizar o problema sem a pretensão imediata de solucioná-lo"(UNIVERSIDADE DE SÃO PAULO 1998).

Conforme os critérios de classificação utilizados por GIL (1996), as pesquisas descritivas e exploratórias apresentam características distintas, podendo ser enquadradas como pesquisas exploratórias aquelas que têm caráter de um estudo preliminar de determinado assunto, com o objetivo de proporcionar maior familiaridade com o problema, permitindo o aprimoramento de idéias. Segundo o autor, as pesquisas exploratórias, na maioria dos casos, assumem a forma de pesquisa bibliográfica ou estudo de caso. Já as pesquisas descritivas, têm por objetivo principal caracterizar, ou seja, descrever as características de um fenômeno ou população ou estabelecer relações entre variáveis. As pesquisas descritivas geralmente assumem a forma de levantamento, utilizando técnicas padronizadas de coleta de dados tais como o questionário e a observação sistemática.

A outra modalidade de tese de doutorado aceita pela FSP/USP, é o estudo analítico, característico das "teses que têm por objetivo investigar e testar, rejeitando ou não hipóteses, através do experimento ou da observação, resultando numa contribuição original" (UNIVERSIDADE DE SÃO PAULO 1998).

$O$ objetivo desta tese consistiu fundamentalmente em caracterizar, através de um levantamento, de que forma a Educação Ambiental vem sendo desenvolvida nas escolas públicas da região de 
estudo. Sendo assim, de acordo com as classificações acima, pode ser enquadrada como uma pesquisa descritiva.

Dada a característica descritiva deste trabalho, as hipóteses não foram claramente explicitadas, embora possam ser devidamente inferidas na introdução deste trabalho.

Os levantamentos são caracterizados pela coleta direta de dados junto a um grupo de pessoas, acerca do problema a ser estudado para, posteriormente, obterem-se conclusões sobre os dados obtidos, mediante análise quantitativa. Têm como uma das principais vantagens a possibilidade de fornecer um conhecimento direto da realidade, sem interpretações do pesquisador, embora os dados possam apresentar uma certa subjetividade pois muitas vezes se referem à percepção que as pessoas têm acerca do fenômeno a ser estudado. São considerados mais adequados aos estudos descritivos que explicativos (GIL 1996).

\subsection{Objeto de estudo}

Para elaboração deste levantamento diagnóstico foram analisadas, durante o ano letivo de 1999, 58 escolas públicas estaduais, do ensino médio e fundamental, situadas no $\mathrm{ABC}$ paulista, nos municípios de Diadema, Ribeirão Pires, Rio Grande da Serra, Santo André e São Bernardo do Campo (Anexo 2). O critério de escolha destas escolas foi a proximidade geográfica em relação à Represa Billings, estando 49 delas situadas dentro dos limites da Bacia do Reservatório Billings e as 9 restantes em área bastante próxima (Anexo 6).

\subsection{Levantamento de dados}

A técnica de coleta de dados utilizada nas escolas foi a do questionamento direto ou interrogação, por ser considerada uma 
técnica adequada ao levantamento de dados nas pesquisas descritivas (HÜBNER 1998; GIL 1991). Como instrumento de coleta de dados foi utilizado o questionário, que juntamente com a entrevista e o formulário, constituem os instrumentos usuais deste tipo de pesquisa (GIL 1996; LAKATOS e MARCONI 1996).

O questionário foi construído com 33 campos divididos em 4 ítens, contendo 25 perguntas fechadas para maior precisão de análise e 8 perguntas de caráter aberto para maior riqueza de informações (Anexo 3).

Após a elaboração do questionário, este foi submetido ao préteste para avaliar sua eficiência como instrumento de coleta de dados (GIL 1991).

Para o pré-teste, foram convidados a responder o questionário, 10 professores de escolas públicas estaduais, os quais foram posteriormente entrevistados acerca das dificuldades de entendimento das questões, clareza e precisão dos termos utilizados e tempo necessário ao preenchimento. O pré-teste permitiu a identificação de problemas de interpretação, linguagem e ordenação das perguntas.

A análise do pré-teste foi utilizada para elaboração dos ajustés considerados necessários à versão final do questionário, com o intuito de assegurar a validade dos dados a serem obtidos, uma vez que as modificações foram elaboradas no sentido de permitir que os professores pudessem compreender satisfatoriamente as perguntas formuladas.

O questionário foi elaborado de forma a permitir uma interação mista entre o indivíduo pesquisado e o pesquisador (HÜBNER 1998). O questionário, impresso em papel, foi encaminhado pessoalmente ao coordenador pedagógico da escola para que este levantasse, junto aos coordenadores dos projetos, os dados solicitados.

Os coordenadores pedagógicos foram orientados a esclarecer aos coordenadores dos projetos, sobre a finalidade da pesquisa e o caráter voluntário de suas participações. 
Cada escola teve, em média, um prazo de 4 semanas para devolver o questionário.

$\mathrm{Na}$ data do recolhimento do questionário, confirmada antecipadamente através de telefonema, foram elucidadas diretamente com os coordenadores dos projetos, as eventuais dúvidas surgidas durante o preenchimento.

Durante o processo de análise dos questionários, quando necessário ao entendimento das respostas, alguns coordenadores de projetos foram novamente contatados para esclarecimentos.

Informações a respeito de projetos externos ( de iniciativa externa), em desenvolvimento nas escolas através de parcerias, foram complementadas utilizando-se a entrevista estruturada ou padronizada (GIL 1991; 1996), contendo um número fixo de perguntas (Anexo 4). O roteiro de perguntas, previamente preparado, foi aplicado à pessoa ligada ao projeto, pertencente à instituição externa parceira.

A análise dos resultados foi feita organizando-se os dados coletados em 5 itens gerais, agrupados por categoria de síntese. Os itens foram agrupados em tópicos de acordo com cada questão formulada, apresentado em cada um, gráficos, estatística percentual simples e breve comentário.

Nas questões abertas foram criadas categorias de análise para agrupar os diferentes dados, de forma a permitir a elaboração de conclusões válidas.

Em alguns itens, foi utilizado um sistema de atribuição de pontos para cada tipo de resposta dada, a fim de se categorizar as respostas de acordo com sua importância, freqüência ou outra priorização.

Foi considerado como "Projeto de Educação Ambiental", qualquer conjunto de atividades envolvendo as questões ambientais, assim definido pelos seus responsáveis. 


\section{RESULTADOS}

Os resultados aqui apresentados refletem aspectos relacionados à situação da Educação Ambiental nas escolas públicas analisadas, durante o ano letivo de 1999.

Devido às constantes modificações das atividades pedagógicas, tais resultados referem-se a esse momento específico das práticas educativas destas escolas.

\subsection{Panorama Geral da Educação Ambiental nas Escolas Analisadas}

\section{Existência de Projetos de Educação Ambiental (EA)}

A - escolas que não têm projetos de EA

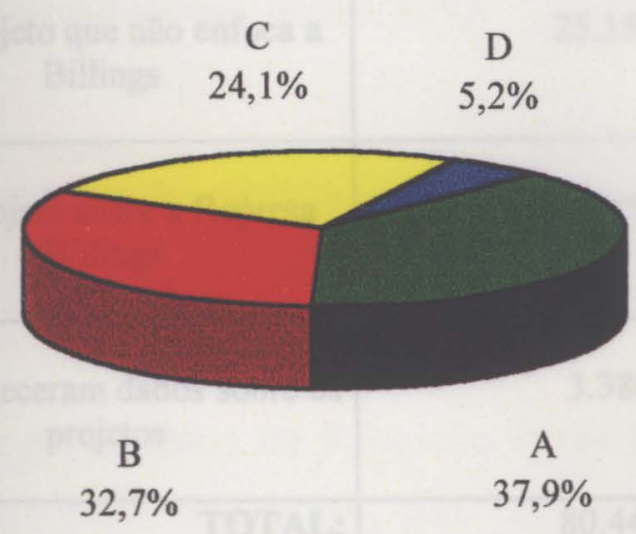

B - escolas que têm projetos de EA que não enfocam a Represa Billings $\square \mathrm{C}$ - escolas que têm projetos de EA referentes à Represa Billings

D - escolas que não forneceram informações sobre os projetos

Figura 1: Existência de projetos de EA nas escolas

Os resultados apresentados na Figura 1 demonstram que $56,8 \%$ das escolas analisadas desenvolvem projetos de Educação Ambiental, embora apenas $24,1 \%$ enfoquem a degradação da Represa Billings nestes projetos. 
Destaca-se um número bastante significativo de escolas que não têm projetos de Educação Ambiental (37,9\%), sendo que 5,2\% não forneceram dados para a pesquisa.

No Anexo 6 deste trabalho pode-se observar a localização das escolas analisadas em relação à Represa Billings, bem como ter-se uma visão geral da existência ou não de projetos de Educação Ambiental nestas escolas.

\section{Número de Estudantes Atendidos nas Escolas Analisadas}

Tabela 1: Número de estudantes atendidos nas escolas analisadas, divididas por categoria com relação aos projetos de Educação Ambiental

\begin{tabular}{c|c|c}
\hline Escolas que & $\mathbf{n}^{\mathbf{0}}$ de estudantes atendidos & \% do total \\
\hline não têm projeto & 30.962 & 38,5 \\
\hline $\begin{array}{c}\text { têm projeto que não enfoca a } \\
\text { Billings }\end{array}$ & 25.154 & 31,3 \\
\hline $\begin{array}{c}\text { Billings } \\
\text { têm projeto sobre a Represa }\end{array}$ & 20.950 & 26,0 \\
\hline $\begin{array}{c}\text { não forneceram dados sobre os } \\
\text { projetos }\end{array}$ & 3.380 & 4,2 \\
\hline TOTAL: & 80.446 & 100,0 \\
\hline
\end{tabular}

De acordo com os dados fornecidos pela Tabela 1, as escolas analisadas são responsáveis pelo atendimento a 80.446 estudantes que residem próximos ou em áreas de proteção de mananciais da Represa Billings, porém, apenas $26 \%$ estudam em escolas que desenvolvem projetos de Educação Ambiental relacionados à Represa e sua degradação. 
No Anexo 2 deste trabalho pode-se verificar a distribuição de alunos por escola analisada.

\section{Distribuição das Escolas por Município}

Tabela 2: Distribuição das escolas por município de acordo com a existência de projetos de Educação Ambiental

\begin{tabular}{|c|c|c|c|c|c|c|c|}
\hline Município & $\begin{array}{l}\mathrm{n}^{\circ} \text { de escolas } \\
\text { analisadas }\end{array}$ & $\begin{array}{l}\text { n }^{\circ} \text { de escolas } \\
\text { com EA sem } \\
\text { Billings }\end{array}$ & $\%$ & $\begin{array}{c}\mathbf{n}^{\circ} \text { de escolas com } \\
\text { EA+Billings: * }\end{array}$ & $\%$ & $\begin{array}{c}\mathbf{n}^{\circ} \text { de escolas } \\
\text { que nāo tem } \\
\text { EA }\end{array}$ & $\%$ \\
\hline Diadema & 10 & 3 & 30,0 & 3 & 30,0 & 2 & 20,0 \\
\hline $\begin{array}{l}\text { São Bernardo } \\
\text { do Campo }\end{array}$ & 25 & 8 & 32,0 & 4 & 16,0 & 12 & 48,0 \\
\hline Santo André & 07 & 1 & 14,3 & 5 & 71,4 & 1 & 14,3 \\
\hline Ribeirão Pires & 09 & 3 & 33,3 & 1 & 11,1 & 5 & 55,6 \\
\hline $\begin{array}{l}\text { Rio Grande da } \\
\text { Serra }\end{array}$ & 07 & 4 & 51,1 & 1 & 14,3 & 2 & 28,6 \\
\hline TOTAL & 58 & 19 & & 14 & & 22 & \\
\hline
\end{tabular}

* escolas que tem projetos de EA que não enfocam a Represa Billings

** escolas que tem projetos de EA sobre a Represa Billings

*** escolas que não tem projetos de EA

OBS: 2 escolas de Diadema e 1 de São Bernardo do Campo não forneceram as informações sobre projetos

Nos municípios de Ribeirão Pires e São Bernardo do Campo, 55,6\% e $48 \%$, respectivamente, das escolas analisadas, não têm projetos de Educação Ambiental.

Já em Santo André, apenas 14,3\% não têm projeto, sendo que $71,4 \%$ têm projeto sobre a Billings e conforme verificado junto a estas escolas, estes projetos fazem parte de uma iniciativa da prefeitura local, a qual foi caracterizada no Anexo 5 deste trabalho. 


\section{Causas da Inexistência de Projetos nas Escolas}

As principais causas apontadas para a inexistência de projetos de Educação Ambiental em 22 das 58 escolas analisadas (Tabela 2) puderam ser agrupadas da seguinte forma:

falta apoio financeiro

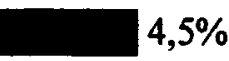

EA é trabalhada como conteúdo de disciplina não há integração entre os professores

falta pessoal capacitado e conhecimento técnico

¿A é trabaihada nos temas transversais
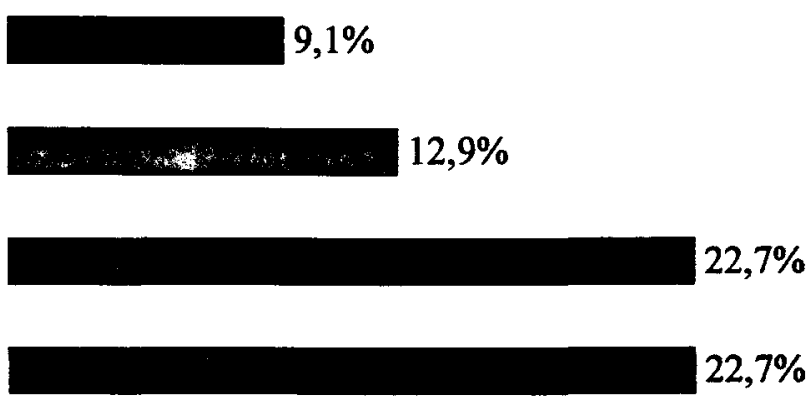

não justificaram

$31,8 \%$

Com relação aos dados acima, é importante ressaltar que para $22,7 \%$ das escolas, o fato da Educação Ambiental ser abordada juntamente com outros temas transversais como Saúde, Orientação Sexual, Trabalho e outros, faz com que não exista um conjunto de atividades específicas sobre Educação Ambiental, o que determina a inexistência de um projeto sobre o assunto. 


\subsection{Perfil do Coordenador do projeto na Escola}

Para análise destes dados, foi levado em consideração o universo de todas as escolas que desenvolvem projetos de Educação Ambiental, num total de 33 escolas envolvendo 35 projetos.

Para 3 dos projetos, as escolas não disponibilizaram as informações uma vez que esclareceram que não existe um único responsável ou coordenador, ficando a condução do projeto distribuída entre todos os professores envolvidos.

Sendo assim, os dados abaixo referem-se à 32 projetos de Educação Ambiental.

\section{Cargo ou Função do Coordenador do Projeto}

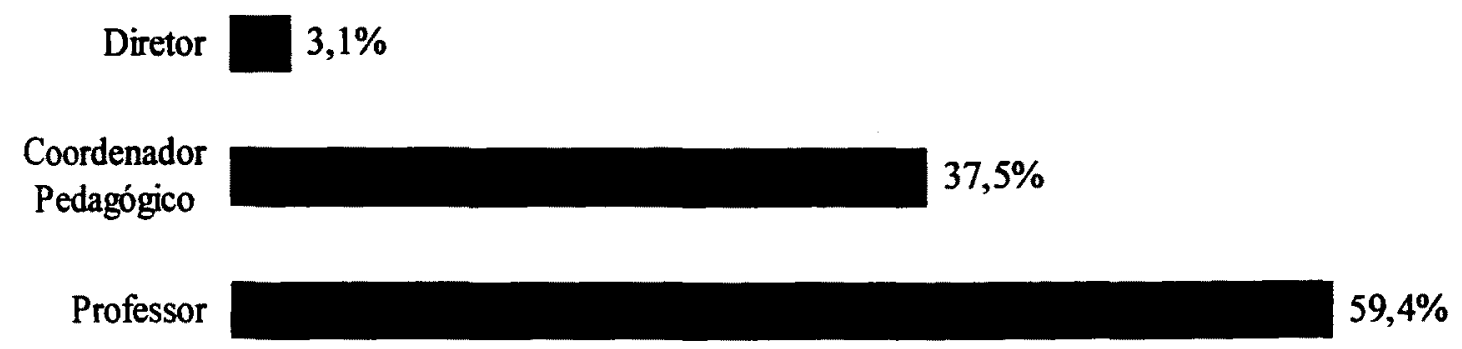

Figura 3: Função exercida pelo coordenador do projeto na escola

Verifica-se que a maior parte dos projetos são coordenados por professores.

o coordenador pedagógico das escolas também atua como coordenador de um número significativo de projetos. 


\section{Área de Formação dos Coordenadores}

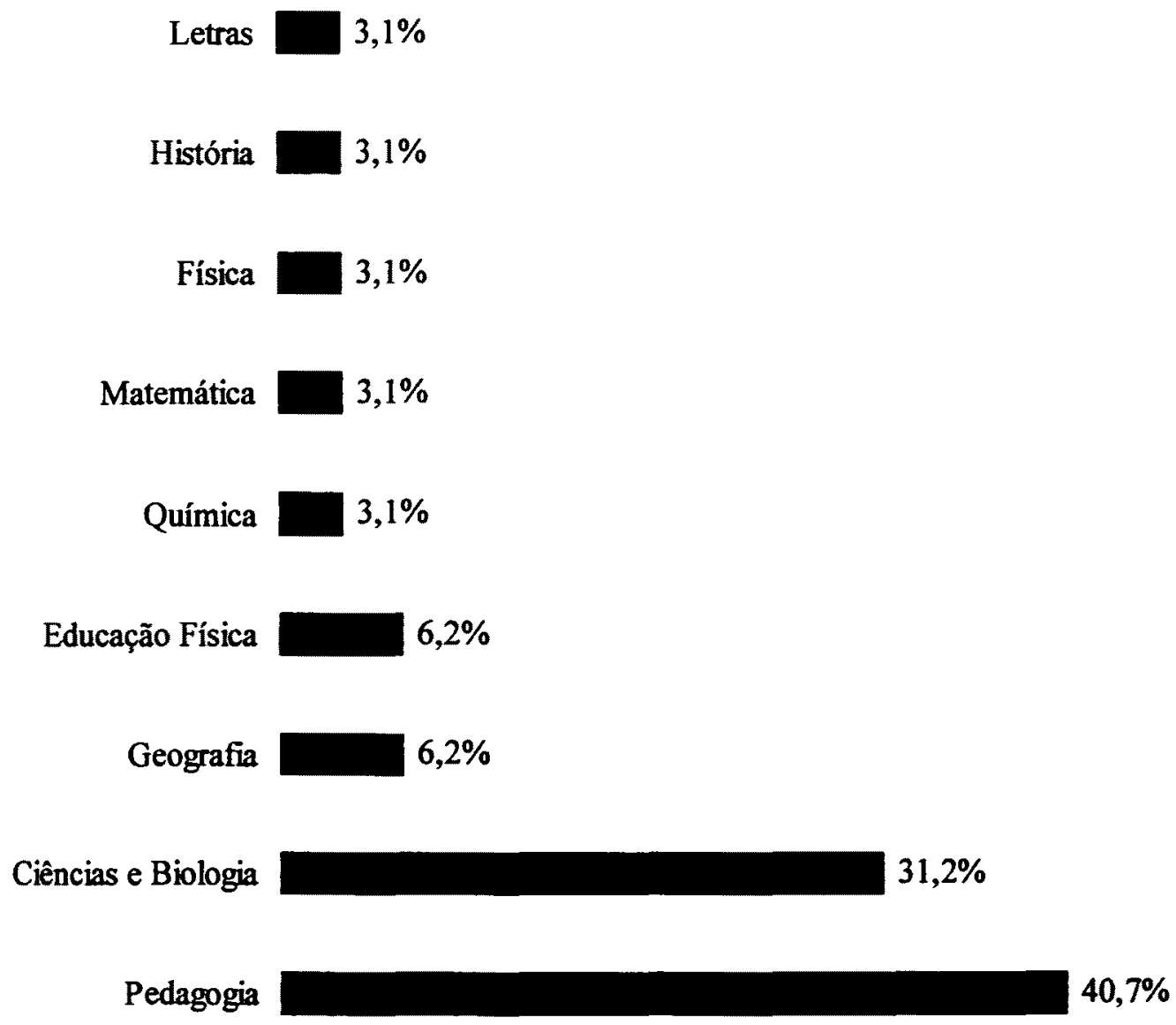

Figura 4: Área de formação dos coordenadores

A pesquisa identificou uma elevada incidência de formação em Pedagogia e Ciências e Biologia, representando 40,7\% e $31,2 \%$, respectivamente.

$O$ restante dos coordenadores tem formação distribuída em Geografia (6,2\%), Educação Física (6,2\%), Química (3,1\%), Matemática $(3,1 \%)$, Física $(3,1 \%)$, História $(3,1 \%)$ e Letras $(3,1 \%)$, o que revela que profissionais das mais diversas áreas estão atuando nos projetos de Educação Ambiental. 


\section{Nível de Escolaridade}

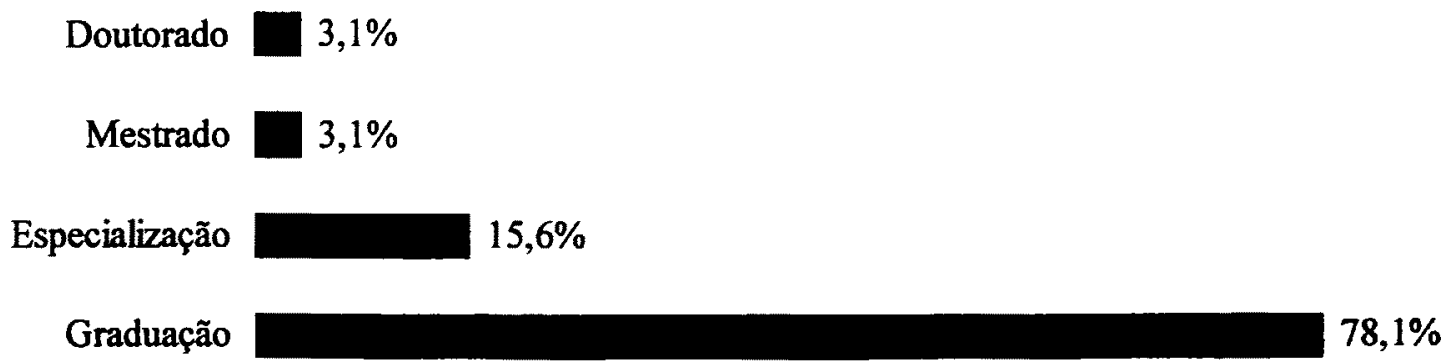

Figura 5: Nível de escolaridade do coordenador

Ao analisar o nível de escolaridade dos coordenadores dos projetos, a pesquisa revelou que a grande maioria $(78,1 \%)$ possui graduação em alguma área específica conforme pode ser observado no item acima.

Poucos revelaram ser pós-graduados com mestrado e doutorado $(3,1 \%$ e $3,1 \%)$.

Alguns coordenadores $(15,6 \%)$ têm cursos de especialização

\section{Capacitação em Educação Ambiental}

Tem formação em Educação Ambiental

Figura 6: Formação dos coordenadores em Educação Ambiental

Quando se faz uma análise da capacitação dos coordenadores dos projetos, verifica-se que apenas $12,5 \%$, representados por 4 professores, apresentam alguma capacitação em Educação Ambiental: três professores têm curso de Aperfeiçoamento em Educação. Ambiental, oferecido pela Delegacia de Ensino de São Bernardo do 
Campo e um dos coordenadores cursou Especialização em Educação Ambiental pela FSP-USP. Os $87,5 \%$ restantes não possuem nenhuma formação específica na área.

\section{Conhecimento acerca dos Documentos e Textos Oficiais}

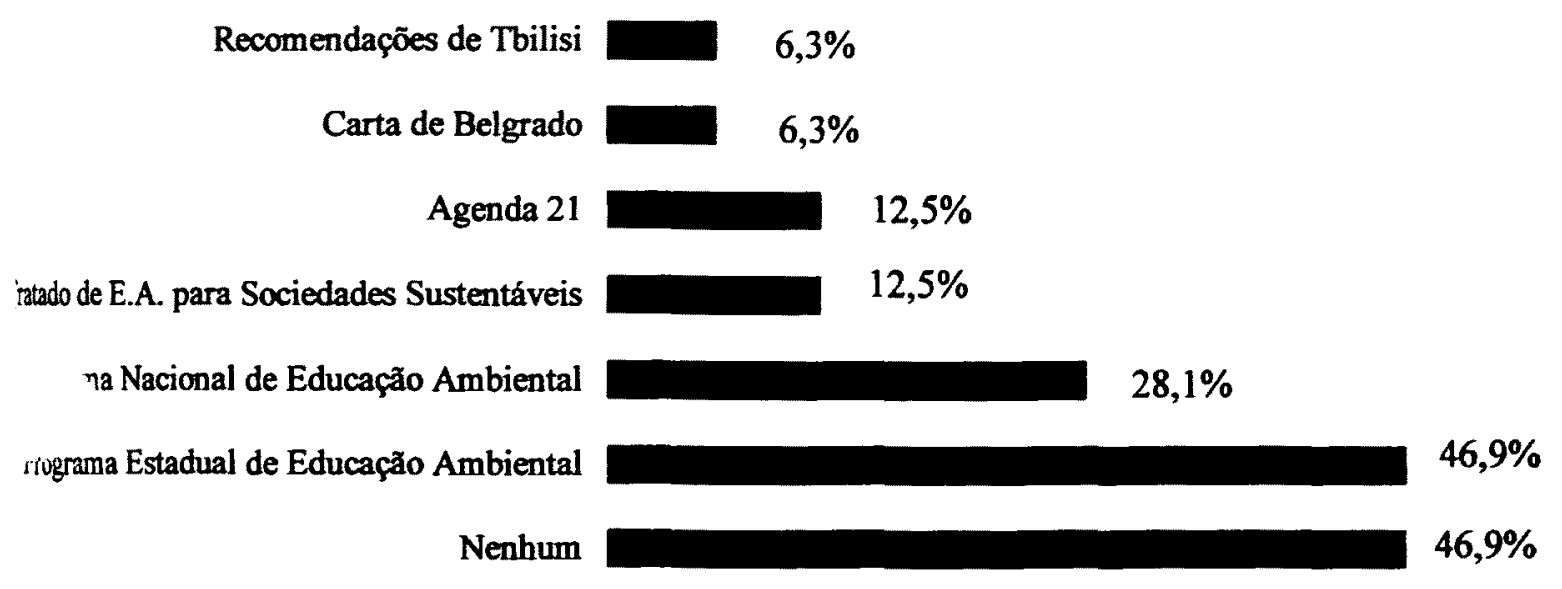

Lei de Proteção aos Mananciais

$53,1 \%$

Figura 7: Documentos e textos oficiais conhecidos pelos coordenadores

Foi possível verificar que a Lei de Proteção aos Mananciais e o Programa Estadual de Educação Ambiental são conhecidos por 53,1\% e $46,9 \%$ dos coordenadores dos projetos, respectivamente.

Vale salientar, entretanto, que $46,9 \%$ dos coordenadores não conhecem nenhum dos documentos e textos oficiais citados ou outros que pudessem ter sido mencionados.

Chama também a atenção o fato de que documentos referenciais importantes como a Agenda 21, Recomendações de Tbilisi e Carta de Belgrado, são conhecidos por uma porcentagem muito pequena dos coordenadores $(12,5 \%, 6,3 \%$ e $6,3 \%$, respectivamente).

Analisando-se separadamente aqueles coordenadores que têm capacitação específica em Educação Ambiental, foi verificado que 
estes estão entre os que conhecem a maioria dos textos e documentos citados.

Quando se estabelece uma análise entre coordenadores de projetos de Educação Ambiental sobre a Represa Billings e aqueles cujos projetos não enfocam a represa em questão, verifica-se que para os citados em primeiro lugar, $71,4 \%$ conhecem a Lei de Proteção aos Mananciais, enquanto que apenas $38,9 \%$ dos coordenadores de projetos de EA que não tratam da Billings, conhecem tal documento.

Interessante também é verificar que aqueles que desconhecem todos os documentos citados concentram-se nos projetos que não abordam a Represa Billings, uma vez que $61,1 \%$ dos coordenadores destes projetos revelaram não conhecer qualquer documento ou texto oficial sobre Educação Ambiental.

Já entre os coordenadores de projetos que enfocam a Represa Billings, apenas $28,6 \%$ se enquadram na mesma condição.

Tabela 3: Conhecimento de textos e documentos oficiais pelos coordenadores dos projetos de Educação Ambiental que enfocam a Billings e os que não enfocam.

\begin{tabular}{l|c|c}
\cline { 2 - 3 } & $\begin{array}{c}\text { Escolas com EA sem } \\
\text { Billings }\end{array}$ & $\begin{array}{c}\text { Escolas com } \\
\text { EA+Billings** }\end{array}$ \\
\hline Nenhum & $61,1 \%$ & $28,6 \%$ \\
\hline Lei de Proteção aos Mananciais & $38,9 \%$ & $71,4 \%$ \\
\hline Programa Estadual de Educação Ambiental & $38,9 \%$ & $57,1 \%$ \\
\hline Programa Nacional de Educação Ambiental & $27,8 \%$ & $28,6 \%$ \\
\hline Agenda 21 & $11,1 \%$ & $14,3 \%$ \\
\hline Tratado de EA para Sociedades Sustentáveis & $11,1 \%$ & $14,3 \%$ \\
\hline Recomendações de Tbilisi & $11,1 \%$ & $-\cdots$ \\
\hline Carta de Belgrado & $11,1 \%$ & - \\
\hline
\end{tabular}

* escolas que têm projetos de EA que não enfocam a Represa Billings

** escolas que tem projetos de EA sobre a Represa Billings 


\subsection{Características dos Projetos}

Foi feita inicialmente uma análise comparativa dos dados relativos aos projetos de Educação Ambiental que não abordam a Represa Billings e os projetos que abordam.

Nos itens onde foram verificadas diferenças significativas entre os dois grupos, os dados foram apresentados separadamente; caso contrário, foram reunidos em um único grupo.

Os dados referem-se a 35 projetos distribuídos em 33 escolas diferentes, dos quais 20 projetos não enfocam a Represa Billings e 15 enfocam.

\section{Situação Atual dos Projetos}

Tabela 4: Situação atual dos projetos de Educação Ambiental nas Escolas analisadas.

\begin{tabular}{l|c|c|c}
\hline \multicolumn{1}{c|}{ Projetos } & $\begin{array}{c}\text { Escolas com EA sem } \\
\text { Billings* }\end{array}$ & $\begin{array}{c}\text { Escolas com } \\
\text { EA+Billings** }\end{array}$ & - TOTAL \\
\hline Em implantação & 4 & 2 & 6 \\
\hline Em desenvolvimento & 14 & 9 & 23 \\
\hline Concluídos & 2 & 3 & 5 \\
\hline Interrompidos & - & 1 & 1 \\
\hline \multicolumn{1}{r|}{ TOTAL } & 20 & 15 & $35^{* * *}$ \\
\hline
\end{tabular}

* escolas que têm projetos de EA que não enfocam a Represa Billings

** escolas que têm projetos de EA sobre a Represa Billings

*** distribuídos em 33 diferentes escolas sendo 19 escolas que têm projetos de Educação Ambiental que não enfocam a Billings e 14 escolas têm projetos de Educação Ambiental sobre a Billings

Entre os 35 projetos analisados apenas 1 encontra-se interrompido. De acordo com as informações da escola, tal projeto teve início em 1998 tendo sido interrompido no mesmo ano devido desarticulação dos professores envolvidos. 
Cinco projetos já foram concluídos: dois com início e conclusão em 1998 e três com início e conclusão em 1999.

Por ocasião do fechamento dos dados, seis projetos encontravam-se em fase de implantação, sendo cinco com previsão para início ainda em 1999 e um no ano letivo de 2000.

No Anexo 7 deste trabalho pode-se ter uma visão geral da situação atual dos projetos de Educação Ambiental desenvolvidos por 33 diferentes escolas, de acordo com sua localização em relação à Represa Billings.

O levantamento mostrou que apenas 23 dos projetos analisados estão em desenvolvimento, assim distribuidos de acordo com o ano de início (Figura 8).

$\mathbf{n}^{0}$ de projetos

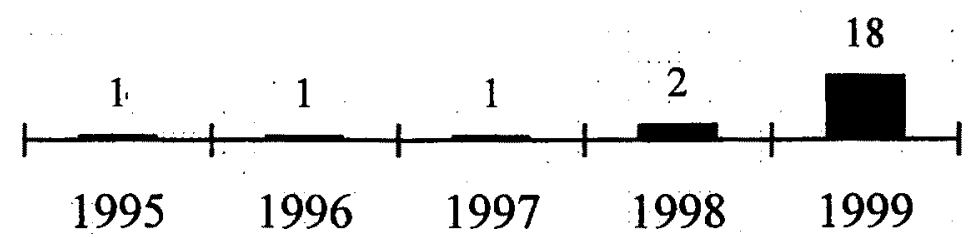

ano de início

Figura 8: Distribuição dos projetos em desenvolvimento de acordo com o ano de início

Os dados da Figura 8 demonstram que 18 dos 35 projetos analisados estão em desenvolvimento há menos de um ano, tendo sido iniciados em 1999.

Um projeto vem sendo desenvolvido desde 1995, um desde 1996, outro desde 1997 e dois desde 1998.

Dos 15 projetos de Educação Ambiental que enfocam a Represa Billings, apenas 9 estão em andamento. 
O Anexo 8 fornece uma perspectiva geral dos projetos de Educação Ambiental que enfocam a Represa Billings, em andamento, de acordo com sua localização em relação ao reservatório.

Tipo de Projeto

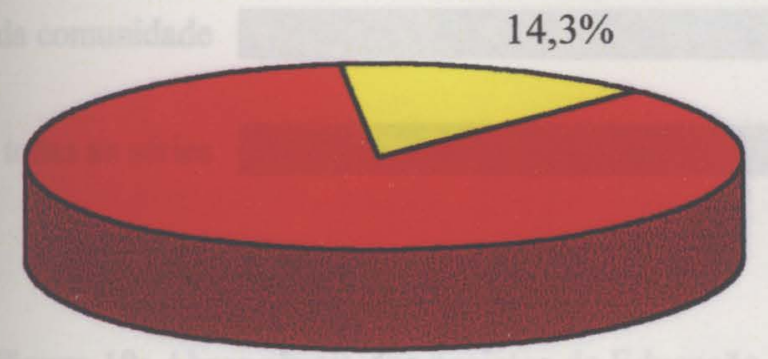

Projetos Multidisciplinares

$85,7 \%$

Figura 9: Tipo de Projeto de acordo com disciplinaridade

Foi verificado que $85,7 \%$ dos projetos são multidisciplinares e apenas $14,3 \%$ são disciplinares.

Os projetos multidisciplinares envolvem pelo menos três disciplinas diferentes que variam de uma escola para outra.

Todos os projetos disciplinares analisados estão ligados à disciplina de Ciências ou Biologia. 


\section{Abrangência dos Projetos}

Dada a diversidade de respostas obtidas para este item, os dados foram agrupados de acordo com as figuras abaixo:

\section{Envolvimento:}

de pais de alunos

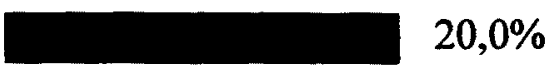

de apenas 1 série

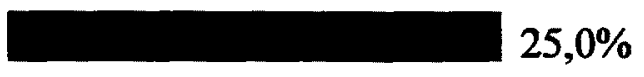

de mais que 1 série

$25,0 \%$

da comunidade

$35,0 \%$

de todas as séries

$50,0 \%$

Figura 10: Abrangência dos projetos de Educação Ambiental que não enfocam a Represa Billings

Envolvimento:

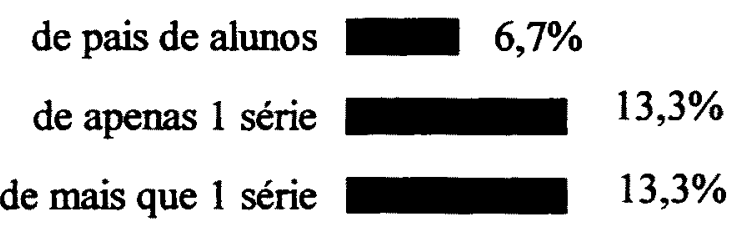

da comunidade

$66,7 \%$

de todas as séries

$73,3 \%$

Figura 11: Abrangência dos projetos de Educação Ambiental que enfocam a Represa Billings

A maior diferença observada entre as escolas cujos projetos abordam a Represa Billings e as que não abordam é que a maioria $(73,3 \%)$ dos projetos que enfocam a Billings são desenvolvidos com 
todas as séries da escola sendo que $66,7 \%$ também incluem a comunidade. No entanto, apenas $50 \%$ dos projetos que não enfocam a Represa Billings tem participação de todas as séries e 35,0\% abrangem também a comunidade.

\section{Principais Objetivos}

Devido às informações muito heterogêneas obtidas no que se refere aos objetivos dos projetos, estes foram inseridos, após a análise dos seus conteúdos, nos seguintes grupos:

Grupo 1. Sensibilização dos estudantes sobre a importância do meio ambiente: neste grupo foram colocados os projetos que tem como objetivo principal despertar nos estudantes a consciência sobre a importância de vários aspectos do ambiente.

Grupo 2. Sensibilização dos estudantes sobre a importância da Represa Billings: projetos que visam principalmente salientar entre os estudantes a importância da Represa Billings para a população local.

Grupo 3. Sensibilização da comunidade sobre a importância do meio ambiente: projetos que objetivam principalmente despertar na comunidade, a consciência sobre a importância de vários aspectos do ambiente.

Grupo 4. Sensibilização da comunidade sobre a importância da Represa Billings: projetos que visam salientar entre a comunidade, a importância da Represa Billings para a população local. 
Grupo 5. Capacitação de pessoal: projetos que priorizam a formação em educação ambiental através de cursos de capacitação para professores e/ou pessoas da comunidade.

Grupo 6. Geração de informações: projetos que visam principalmente gerar informações sobre o meio ambiente e comunidade de entorno.

Grupo 7. Conservação dos recursos naturais através da reciclagem: projetos que envolvem basicamente a reciclagem de materiais como forma de conservação dos recursos naturais.

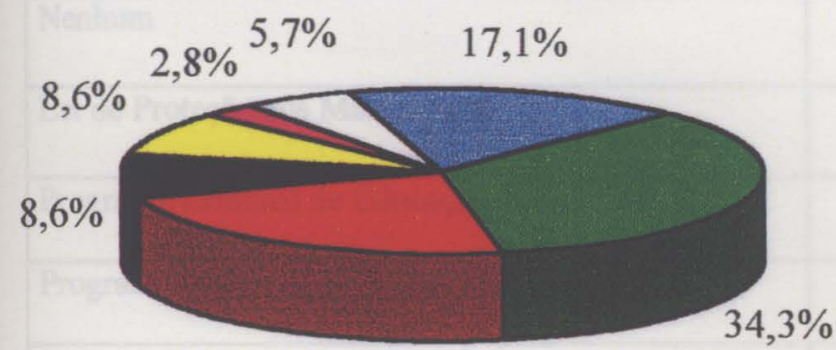

$22,8 \%$
Sensibilização dos estudantes sobre o meio ambiente 口 Sensibilização dos estudantes sobre a Represa Billings Sensibilização da comunidade sobre o meio ambiente $\square$ Sensibilização da comunidade sobre a Represa Billings $\square$ Capacitação de pessoal

$\square$ Geração de informações

Conservação dos recursos naturais pela reciclagem

Figura 12: Principal objetivo dos projetos analisados

Analisando-se os objetivos apontados nos 35 projetos, verificou-se que a maioria prioriza com suas atividades alcançar objetivos mais gerais como a sensibilização do corpo discente $(34,3 \%)$ e da comunidade $(8,6 \%)$ sobre a importância do meio ambiente para o homem.

Outros projetos têm objetivos mais específicos: $22,8 \%$ dos projetos procuram sensibilizar os estudantes sobre a importância da Represa 
Billings e $8,6 \%$ objetivam sensibilizar a comunidade sobre o mesmo aspecto.

Poucos projetos têm objetivos bem específicos: apenas 5,7\% procuram gerar informações sobre meio ambiente de entorno e um único projeto $(2,8 \%)$ objetiva a capacitação de pessoal em Educação Ambiental. É interessante observar que um número significativo de projetos $(17,1 \%)$ têm como objetivo reciclar materiais como forma de conservação dos recursos naturais.

\section{Textos e Documentos Oficiais que Subsidiam os Projetos}

Tabela 5: textos e documentos oficiais que subsidiam os projetos que não enfocam a Represa Billings e os que enfocam

\begin{tabular}{|l|c|c|}
\cline { 2 - 3 } \multicolumn{1}{c|}{} & $\begin{array}{c}\text { Projetos de EA sem } \\
\text { Billings }\end{array}$ & $\begin{array}{c}\text { Projetos de } \\
\text { EA+Billings }\end{array}$ \\
\hline Nenhum & $60,0 \%$ & $26,7 \%$ \\
\hline Lei de Proteção aos Mananciais & $40,0 \%$ & $60,0 \%$ \\
\hline Programa Nacional de Educação Ambiental & $40,0 \%$ & $40,0 \%$ \\
\hline Agenda 21 & $30,0 \%$ & $26,7 \%$ \\
\hline Tratado de EA para Sociedades Sustentáveis & $10,0 \%$ & $20,0 \%$ \\
\hline Recomendações de Tbilisi & $5,0 \%$ & $20,0 \%$ \\
\hline Carta de Belgrado & -- & -- \\
\hline
\end{tabular}

* projetos de Educação Ambiental que não enfocam a Represa Billings

** projetos de Educação Ambiental sobre a Represa Billings

Observa-se uma diferença na utilização dos textos e documentos oficiais para subsidiar os projetos dos 2 grupos. Sessenta por cento dos projetos que não enfocam a Represa Billings, não são subsidiados por nenhum texto ou documento oficial, enquanto que apenas $26,7 \%$ dos projetos que enfocam a Billings estão nesta condição. 
No que se refere à "Lei de Proteção aos Mananciais", este documento foi citado em $60 \%$ dos projetos como sendo o mais utilizado como subsídio para os projetos que enfocam a Represa Billings. Os textos mais utilizados nos projetos que não enfocam a Represa Billings são o "Programa Estadual de Educação Ambiental" e a "Lei de Proteção aos Mananciais" os quais servem como subsídio para $40 \%$ dos projetos deste grupo.

\section{Planejamento}

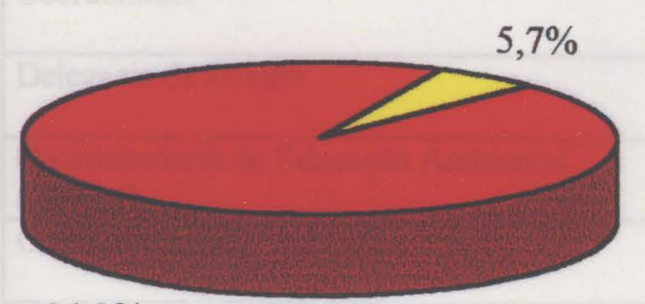

Obedecem planejamento

$94,3 \%$

Figura 13: Distribuição dos projetos de acordo com existência ou não de planejamento

De acordo com os dados levantados na pesquisa, 94,3\% dos projetos obedecem algum tipo de planejamento e apenas $5,7 \%$ são desenvolvidos sem planejamento algum.

$31,4 \%$

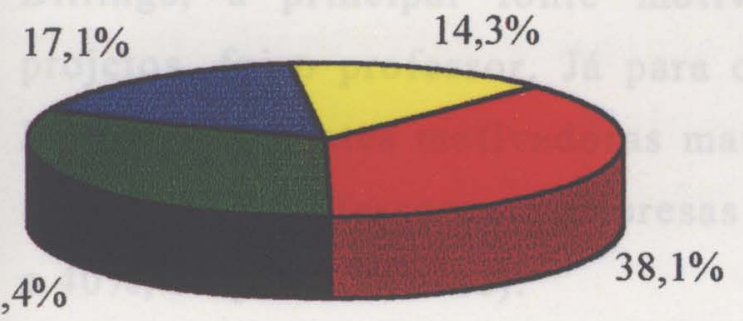

Anual

Bimestral

Mensal

Apenas no início

Figura 14: Tipo de planejamento realizado 
Já com referência ao tipo de planejamento, a predominância é de projetos cujo planejamento é anual $(37,1 \%)$ ou bimestral $(31,4 \%)$.

Fonte Motivadora

Tabela 6: Fonte motivadora dos projetos

\begin{tabular}{|l|c|c|}
\cline { 2 - 3 } \multicolumn{1}{c|}{} & $\begin{array}{c}\text { Projetos de EA sem } \\
\text { Billings }^{\star}\end{array}$ & Projetos de EA+Billings \\
\hline Professor & $75,0 \%$ & $40,0 \%$ \\
\hline Diretor & $35,0 \%$ & $20,0 \%$ \\
\hline Coordenador & $35,0 \%$ & $6,7 \%$ \\
\hline Delegacia de Ensino & $20,0 \%$ & - \\
\hline $\begin{array}{l}\text { Coordenadoria de Educação Ambiental } \\
\text { (CEAM) }\end{array}$ & - & - \\
\hline Corpo discente & $5,0 \%$ & $20,0 \%$ \\
\hline Comunidade & - & $6,7 \%$ \\
\hline Prefeituras Municipais & $10,0 \%$ & $46,7 \%$ \\
\hline Empresas e Fundaç̃̃es Privadas & $25,0 \%$ & $40,0 \%$ \\
\hline
\end{tabular}

* projetos de Educação Ambiental que não enfocam a Represa Billings

** projetos de Educação Ambiental que enfocam a Represa Billings

Para este item, as escolas mencionaram mais de uma fonte motivadora dos projetos.

É interessante salientar que nos projetos que não enfocam a Represa Billings, a principal fonte motivadora, mencionada em $75 \%$ dos projetos, foi o professor. Já para os projetos que enfocam a Represa Billings as fontes motivadoras mais mencionada foram as prefeituras municipais, professores e empresas e fundações privadas $(46,7 \%, 40 \%$ e $40 \%$, respectivamente).

Foram mencionadas as seguintes empresas e fundações: Fundação Roberto Marinho, Instituto Antônio Carlos Jobin, World Wildlife Fund 
- WWF, Associação Brasileira da Indústria de Álcalis e Cloro Derivados - Abiclor, Latasa S.A., Solvay do Brasil S. A.

Vale ressaltar que apesar de serem escolas estaduais, nenhuma mencionou a Coordenadoria de Educação Ambiental da Secretaria do Estado do Meio Ambiente (CEAM), como fonte motivadora dos projetos.

\section{Parcerias}

Com relação às parcerias, foi verificado que 4 dos 20 projetos que não enfocam a Represa Billings têm parcerias (20\%), e 10 dos 15 projetos que abordam a Represa Billings também têm parcerias $(66,7 \%)$.

Tabela 7: Existência de parcerias no desenvolvimento dos projetos

\begin{tabular}{|l|c|c|}
\cline { 2 - 3 } \multicolumn{1}{c|}{} & $\begin{array}{c}\text { Projetos de EA sem } \\
\text { Billings }\end{array}$ & Projetos de EA+Billings \\
\hline Tem parcerias & $20,0 \%$ & $66,7 \%$ \\
\hline Não tem parcerias & $80,0 \%$ & $33,3 \%$ \\
\hline
\end{tabular}

* projetos de Educação Ambiental que não enfocam a Represa Billings

** projetos de Educação Ambiental que enfocam a Represa Billings

Foi possível verificar a existência de dois tipos diferentes de projetos, classificados da seguinte forma com relação às parcerias:

- projetos internos - projetos de iniciativa da própria escola que recebem apoio de instituições parceiras.

- projetos externos - projetos de iniciativa de instituições parceiras sendo desenvolvidos na escola. 
A forma de parceria pode ser observada na Tabela 8.

Tabela 8: Forma de parceria entre as escolas e instituições parceiras

\begin{tabular}{l|c|c}
\hline \multicolumn{1}{c|}{ Forma de Parcerias* } & $\begin{array}{c}\text { Projetos de EA sem } \\
\text { Billings** }\end{array}$ & Projetos de EA+Billings $^{\star \star \star}$ \\
\hline Apoio técnico & $50,0 \%$ & $50,0 \%$ \\
\hline Recursos didáticos & $75,0 \%$ & $70,0 \%$ \\
\hline Apoio financeiro & $100 \%$ & - \\
\hline Recursos humanos & $75,0 \%$ & $70,0 \%$ \\
\hline
\end{tabular}

* citadas em 4 projetos de EA sem Billings e em 10 projetos com Billings

** projetos de Educação Ambiental que não enfocam a Represa Billings

*** projetos de Educação Ambiental que enfocam a Represa Billings

Cruzando os dados deste item com a situação atual destes projetos pode-se obter o seguinte quadro:

Tabela 9: Situação atual dos projetos em parcerias

\begin{tabular}{l|c|c|c}
\hline \multicolumn{1}{c|}{ Instituição Parceira } & $\begin{array}{c}\text { N.` de } \\
\text { Projetos }\end{array}$ & Tipo de Projeto & Situação Atual \\
\hline $\begin{array}{l}\text { Fundação Roberto Marinho/ Instituto Tom } \\
\text { Jobin }\end{array}$ & 2 & EA sem Billings & Em implantação \\
\hline Lara Lixo Reciclável & 1 & EA sem Billings & Em desenvolvimento \\
\hline Latasa S.A. & 1 & EA sem Billings & Em desenvolvimento \\
\hline Lions Clube de Diadema & 1 & EA com Billings & Em desenvolvimento \\
\hline Movimento em Defesa da Vida & 1 & EA com Billings & Concluído \\
\hline Prefeitura de Diadema & 1 & EA com Billings & Interrompido \\
\hline Prefeitura de Ribeirão Pires & 1 & EA com Billings & Em desenvolvimento \\
\hline Prefeitura de Santo André & 5 & EA com Billings & Em desenvolvimento \\
\hline Solvay do Brasil S.A. & 1 & EA com Billings & Concluído \\
\hline
\end{tabular}


Observa-se que dos 10 projetos que abordam a Represa Billings e têm parcerias, 7 estão em desenvolvimento.

Os projetos desenvolvidos em parceria com a Fundação Roberto Marinho, Solvay do Brasil S.A., Prefeitura de Ribeirão Pires e Prefeitura de Santo André, são de iniciativa destas instituições ( projetos externos).

Dados adicionais sobre os projetos externos em desenvolvimento (Prefeitura de Ribeirão Pires e Prefeitura de Santo André), foram obtidos através de entrevista de acordo com o roteiro especificado no anexo 4.

A instituição parceira responsável pelo maior número de projetos em andamento, é a Prefeitura Municipal de Santo André através do projeto "Água Limpa, Viva Vida" do Serviço Municipal de Água e Saneamento de Santo André - SEMASA.

Este projeto foi utilizado como um exemplo de projeto externo em parceria, uma vez que enfoca a preservação da Represa Billings (Anexo 5).

O projeto “Água Limpa, Viva a Vida" está atualmente em andamento em cinco das escolas analisadas.

Após a entrevista, realizada com um dos membros da equipe do SEMASA, as informações relativas ao projeto foram fornecidas por escrito de acordo com o roteiro das perguntas do Anexo 4 . 


\section{Custo Anual do Projeto}

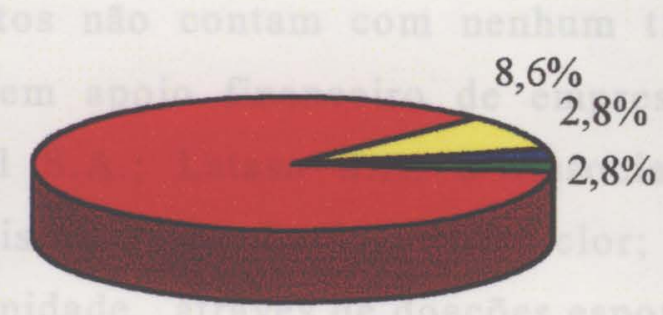

$85,7 \%$ $\square$ até $\mathrm{R} \$ 500,00$

Ede $R \$ 501,00$ à $R \$ 1000,00$

$\square$ de $\mathrm{R} \$ 3000,00$ à $\mathrm{R} \$ 4000,00$

口 Sem estimativa

Figura 15: Custo anual do projeto

Foi observado que $85,7 \%$ dos 35 projetos analisados são desenvolvidos sem que se tenha uma estimativa do seu custo anual (ou total).

\section{Apoio Financeiro}

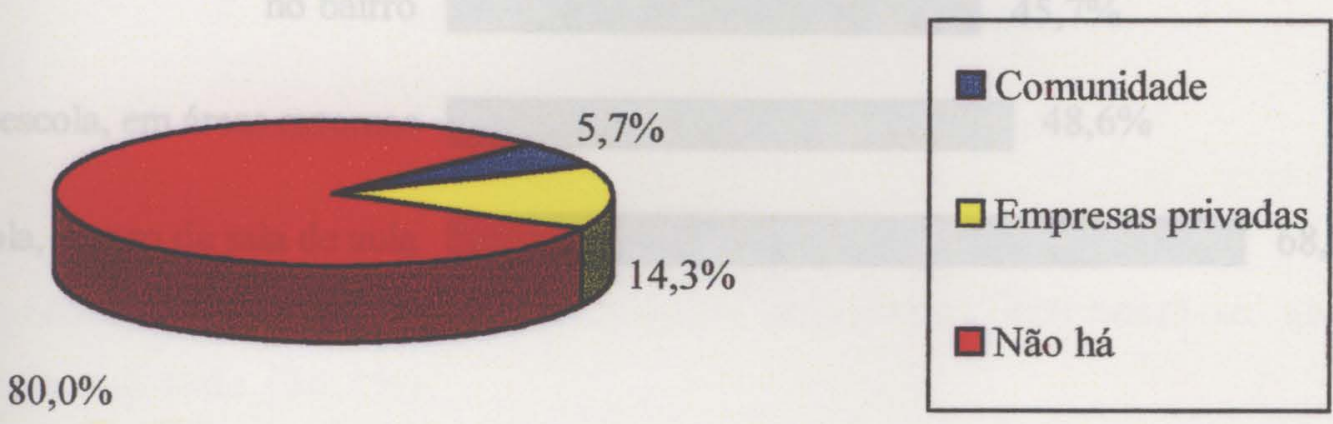

Figura 16: Tipo de apoio financeiro recebido 
Neste item procurou-se analisar se as escolas recebem algum tipo de apoio financeiro para desenvolvimento dos projetos.

De acordo com os resultados da Figura 16, verificou-se que $80 \%$ dos projetos não contam com nenhum tipo de apoio financeiro; 14,3\% recebem apoio financeiro de empresas privadas como a Solvay do Brasil S.A.; Latasa S.A. e Associação Brasileira da Indústria de Álcalis e Cloro Derivados-Abiclor; 5,7\% têm apoio financeiro da comunidade, através de doações espontâneas e arrecadação obtidas em eventos realizados pelas Associações de Pais e Mestres - APMs.

\title{
Locais Onde São Desenvolvidas As Atividades
}

\author{
em áreas próximas à Billings $\square, 7 \%$ \\ nas residências dos alunos $\square 5,7 \%$ \\ em parques públicos $\square 5,7 \%$
}

no bairro $45,7 \%$

na escola, em áreas externas $\square 48,6 \%$

$\begin{array}{lll}\text { na escola, dentro da sala de aula } & 68,6 \%\end{array}$

Figura 17: Locais onde são desenvolvidas as atividades do projeto 
Através da Figura 17 é possível verificar que a maior parte das atividades são desenvolvidas em sala de aula $(68,6 \%)$.

Uma porcentagem pequena das atividades é desenvolvida em locais como parques, residências e áreas próximas à Billings.

\section{Duração das Atividades}

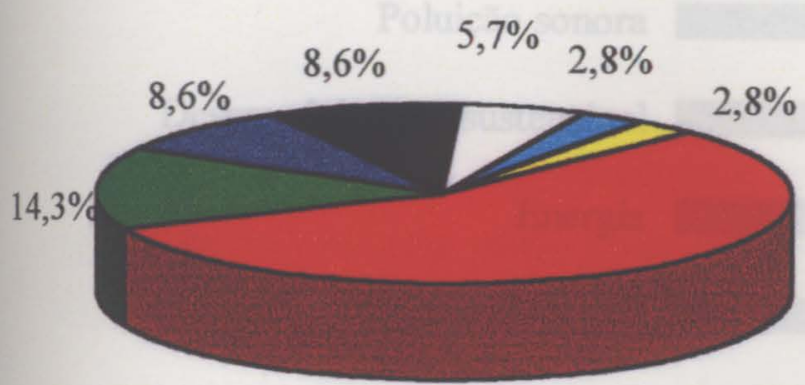

$54,3 \%$ $\square$ Ano letivo todo

$\square 1$ bimestre

2 bimestres

1 semestre

$\square 2$ anos

口 1 semana

$\square$ sem previsão

Figura 18: Duração das atividades do projeto

A predominância é de projetos cujas atividades estendem-se ao longo do ano todo $(54,3 \%)$. 


\section{Temas Abordados nos Projetos}

\section{Desmatamento $\mathbf{\square} 2,8 \%$}

Preservação do patrimônio histórico $\square 2,8 \%$

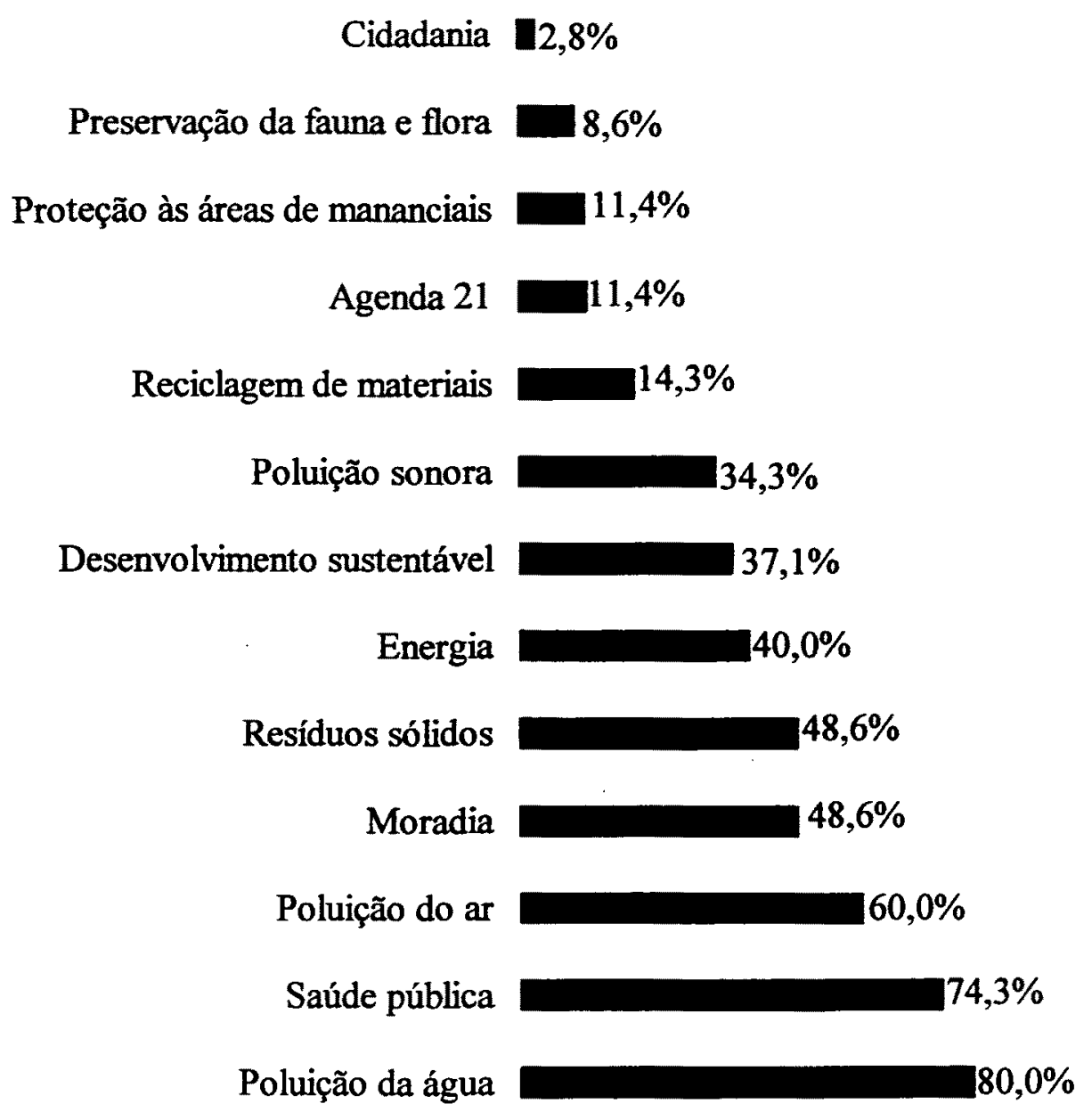

Figura 19: Principais temas abordados nos projetos

A análise da Figura 19 demonstra que os temas mais abordados pelos projetos são: Poluição da água $(80,0 \%)$, Saúde da População $(74,3 \%)$ e Poluição do $\operatorname{Ar}(60,0 \%)$. Uma porcentagem significativa dos projetos também incluem temas como Moradia (48,6\%), Resíduos Sólidos (48,6\%), Energia (40,0\%), Desenvolvimento Sustentável $(37,1 \%)$ e Poluição Sonora $(34,3 \%)$. 


\section{Atividades Utilizadas}

Para se ter uma noção de quais atividades são utilizadas com mais freqüência durante o desenvolvimento dos projetos, foi estabelecido um sistema de pontuação e para cada menção, no questionário, foram atribuídos pontos, de acordo com o seguinte critério:

\section{Muito freqüente $=3$ pontos \\ Freqũente $=2$ pontos \\ Pouco freqüente $=1$ ponto}

Nunca $=$ zero

Depois de atribuidos os pontos para cada menção, foi levantado o total geral obtido em cada grupo de atividade e estas foram classificadas, conforme pode ser observado na Tabela 10.

Responderam a este item 31 escolas, sendo 19 escolas que tem projeto de Educação Ambiental que não enfocam a Represa Billings e 12 escolas com projetos relacionados à Represa Billings 
Tabela 10: Atividades utilizadas por ordem de frequência

\begin{tabular}{|c|c|c|c|c|}
\hline \multirow[b]{2}{*}{ Classificação } & \multicolumn{2}{|c|}{$\begin{array}{c}\text { * Escolas com projetos que não enfocam } \\
\text { Billings }\end{array}$} & \multicolumn{2}{|c|}{$\begin{array}{l}* \star \text { Escolas com projetos que enfocam } \\
\text { Billings }\end{array}$} \\
\hline & Atividades & Pontuação & Atividades & Pontuação \\
\hline $1^{\circ}$ & $\begin{array}{l}\text { Confecção de material } \\
\text { didático }\end{array}$ & 44 & Estudo de texto & 28 \\
\hline $2^{\circ}$ & Exposições & 41 & Discussão em grupos & 27 \\
\hline $3^{\circ}$ & Discussão em grupos & 40 & $\begin{array}{c}\text { Confeção de material } \\
\text { didático }\end{array}$ & 26 \\
\hline $4^{\circ}$ & Estudo de texto & 39 & Debate & 26 \\
\hline $5^{\circ}$ & Aula expositiva/palestra & 36 & Aula expositiva/palestra & 25 \\
\hline $6^{\circ}$ & Campanhas educativas & 33 & Projeção de vídeos & 25 \\
\hline $7^{\circ}$ & Projeção de vídeos & 33 & Exposições & 23 \\
\hline $8^{\circ}$ & Debate & 32 & Campanhas educativas & 22 \\
\hline $9^{\circ}$ & Pesquisa bibliográfica & 29 & Excursão/estudo do meio & 19 \\
\hline $10^{\circ}$ & Comemorações & 26 & Pesquisa bibliográfica & 18 \\
\hline $11^{\circ}$ & Seminários & 24 & Aula prática em campo & 17 \\
\hline $12^{\circ}$ & $\begin{array}{l}\text { Atividades com a } \\
\text { comunidade }\end{array}$ & 22 & Oficinas & 15 \\
\hline $13^{\circ}$ & Aula prática em campo & 22 & Comemorações & 15 \\
\hline $14^{\circ}$ & Oficinas & 20 & $\begin{array}{l}\text { Atividades com a } \\
\text { comunidade }\end{array}$ & 14 \\
\hline $15^{\circ}$ & Excursão/estudo do meio & 20 & Seminários & 11 \\
\hline $16^{\circ}$ & Aula prática em laboratório & 9 & Aula prática em laboratório & \\
\hline
\end{tabular}

\section{Critérios de Avaliação dos Projetos e Periodicidade}

No que se refere a este item do questionário, várias formas de avaliação foram citadas. Apesar da grande diversidade de respostas, as diferentes formas de avaliação puderam ser agrupadas conforme a Figura 20.

Os critérios utilizados nestas avaliações, porém, não foram estabelecidos. Sendo assim, as respostas indicaram apenas de que 
forma é feita a avaliação e não o que é avaliado (comportamento, mudanças de valores, conhecimento, etc).

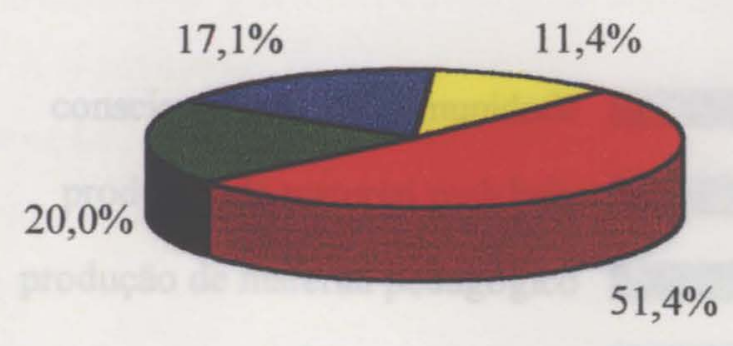

Análise e discussão das atividades desenvolvidas pelos alunos, feita pelo grupo de professores envolvidos

Avaliação da participação dos alunos em sala de aula, feita pelo professor

Análise de relatórios dos professores, feita pelo coordenador do projeto

Avaliação feita pela instituição parceira

Figura 20: Formas de avaliação dos projetos

Quanto à periodicidade da avaliação, foram verificados os seguintes resultados:

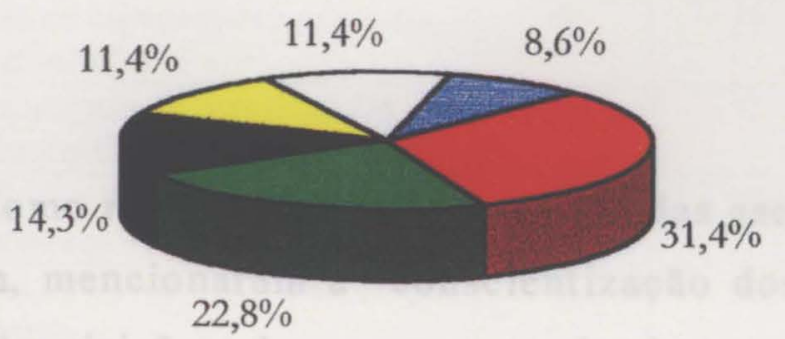

\begin{tabular}{|l|}
\hline$\square$ Bimestral \\
$\square$ Contínua \\
$\square$ No final do projeto \\
$\square$ Mensal \\
$\square$ Semestral \\
anual \\
\hline
\end{tabular}

Figura 21: Periodicidade das avaliações dos projetos 


\section{Principais Resultados}

Foram mencionados apenas resultados qualitativos os quais, como nos itens anteriores que envolvem perguntas abertas, foram agrupados em categorias a fim de aglutinar as respostas por blocos semelhantes.

$\begin{array}{ll}\text { conscientização da comunidade } & 9,5 \% \\ \text { produção de material reciclado } & 9,5 \%\end{array}$

produção de material pedagógico — $14,3 \%$

integração entre professores e alunos $14,3 \%$

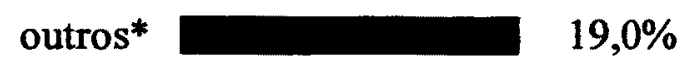

$\begin{array}{ll}\text { participação dos alunos } & 38,1 \%\end{array}$

aquisição de novos conhecimentos $\quad 38,1 \%$

$\begin{array}{lll}\text { conscientização dos alunos } & 47,6 \%\end{array}$

Figura 22: Principais resultados obtidos nos projetos**

* "produção de verduras", "retorno financeiro", "plantio de mudas", "desenvolvimento de projetos".

** de acordo com respostas dadas para 21 projetos, sendo $16 \mathrm{em}$ desenvolvimento e 5 concluídos.

Como resultados obtidos, $47,6 \%$ das escolas que responderam a este item, mencionaram a "conscientização dos alunos"; 38,1\% referem-se à "aquisição de novos conhecimentos" e $38,1 \%$ destacam a "participação dos alunos" como um resultado.

A "integração entre alunos e professores" e "produção de material pedagógico" foram citados por $14,3 \%$ das escolas; 9,5\% destacaram a "produção de material reciclado" e "conscientização da comunidade". 


\section{Principais Dificuldades}

A fim de categorizar as dificuldades encontradas, por ordem de importância, foi estabelecido um sistema de pontuação: as dificuldades receberam 3 pontos por menção quando citadas em primeiro lugar, 2 pontos quando em segundo e 1 ponto quando citadas em terceiro lugar. Em nenhum dos questionários foram mencionadas mais de três dificuldades para desenvolvimento dos projetos.

A pontuação final foi obtida pela soma dos pontos atribuídos a cada menção, por tipo de dificuldade.

As dificuldades citadas foram enquadradas em 10 categorias, conforme tabela abaixo.

Tabela 11: Principais dificuldades encontradas para desenvolvimento dos projetos.

\begin{tabular}{|c|c|c|c|c|c|}
\hline & \multicolumn{3}{|c|}{ Pontos por Mencões } & \multirow[b]{2}{*}{$\begin{array}{c}\text { Pontuaçâo } \\
\text { Final }\end{array}$} & \multirow[b]{2}{*}{ Classificação } \\
\hline Tipo de Dificuldade & $\begin{array}{l}\text { Em 1 }^{\circ} \\
\text { Lugar* }^{*}\end{array}$ & $\begin{array}{c}\operatorname{Em~2}^{\circ} \\
\text { Lugar }^{* \star}\end{array}$ & $\begin{array}{c}\operatorname{Em~3}^{\circ} \\
\operatorname{Lugar}^{* * *}\end{array}$ & & \\
\hline $\begin{array}{l}\text { Falta de conhecimento dos } \\
\text { professores sobre os conteúdos } \\
\text { abordados }\end{array}$ & 21 & 8 & 1 & 30 & $1^{\circ}$ \\
\hline $\begin{array}{l}\text { Inexistência de horário } \\
\text { remunerado específico para } \\
\text { dedicar ao projeto }\end{array}$ & 15 & 12 & 2 & 29 & $2^{\circ}$ \\
\hline $\begin{array}{l}\text { Falta de participação da } \\
\text { comunidade }\end{array}$ & 18 & 6 & 1 & 25 & $3^{\circ}$ \\
\hline $\begin{array}{l}\text { Falta de material didático- } \\
\text { pedagógico }\end{array}$ & 6 & 8 & 2 & 16 & $4^{\circ}$ \\
\hline $\begin{array}{l}\text { Falta de espaço físico adequado } \\
\text { as atividades }\end{array}$ & 9 & 6 & $\overline{-\cdots-}$ & 15 & $5^{\circ}$ \\
\hline $\begin{array}{l}\text { Inexistência ou insuficiência de } \\
\text { recursos financeiros }\end{array}$ & 9 & 2 & 2 & 13 & $6^{\circ}$ \\
\hline $\begin{array}{l}\text { Dificuldades para realizar } \\
\text { atividades externas }\end{array}$ & 3 & 6 & 4 & 13 & $7^{\circ}$ \\
\hline $\begin{array}{l}\text { Falta de envolvimento do corpo } \\
\text { docente }\end{array}$ & 3 & 2 & 1 & 6 & $8^{\circ}$ \\
\hline Ausência de parcerias externas & - & 2 & 3 & 5 & $9^{\circ}$ \\
\hline Falta de interesse da direção & - & - & 1 & 1 & $10^{\circ}$ \\
\hline
\end{tabular}

3 pontos por menção

** 2 pontos por menção

*** 1 ponto por menção 


\subsection{A Represa Billings no Contexto dos Projetos}

Neste item foram analisados aspectos relacionados aos 15 projetos que enfocam a Represa Billings como temática.

\section{Especificidade dos Projetos em Relação à Represa Billings}

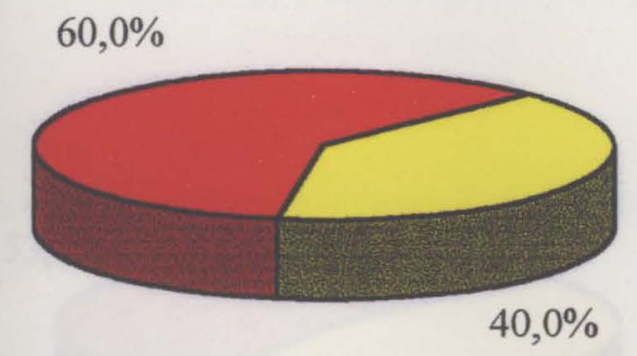

$\square$ projetos específicos sobre a Represa Billings

projetos que não são específicos sobre a Represa Billings

Figura 23: Especificidade dos projetos em relação à Represa Billings

Dos 15 projetos analisados, $40 \%$ (6 projetos) são específicos sobre a Represa Billings, os outros $60 \%$ ( 9 projetos) incluem a Represa Billings juntamente com outros temas ambientais.

\section{Descrição dos Projetos}

A descrição dos projetos forneceu informações bastante heterogêneas, as quais foram utilizadas para se efetuar uma apreciação qualitativa dos diferentes projetos.

A análise deste item, apesar da heterogeneidade permitiu agrupar os projetos em dois grupos distintos: 
Grupo 1: neste grupo foram incluídos os projetos cuja descrição sugere atividades interligadas, desenvolvidas de forma articulada e seguindo uma certa sistematização.

Grupo 2: neste segundo grupo foram incluídos os projetos cuja descrição sugere o desenvolvimento de atividades desarticuladas, sem vínculo temático ou metodológico entre si.

De acordo com a caracterização, entre os 15 projetos analisados, sete foram enquadrados no grupo $1(46,7 \%)$ e oito no $2^{\circ}$ grupo $(53,3 \%)$.

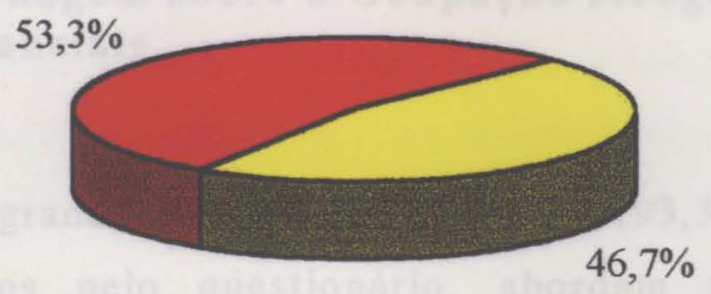

$\square$ Grupo 1: atividades integradas

Grupo 2: atividades desarticuladas

Figura 24: Caracterização dos projetos de acordo com a descrição

\section{Participação da Comunidade}

A participação da comunidade é registrada em $66,7 \%$ dos projetos e foi mencionada nas seguintes atividades propostas:

- oficinas de reaproveitamento de material

- palestras e reuniões

- exposições

- passeios ecológicos

- plantio de mudas 
Em 33,3\% dos projetos não há participação da comunidade.

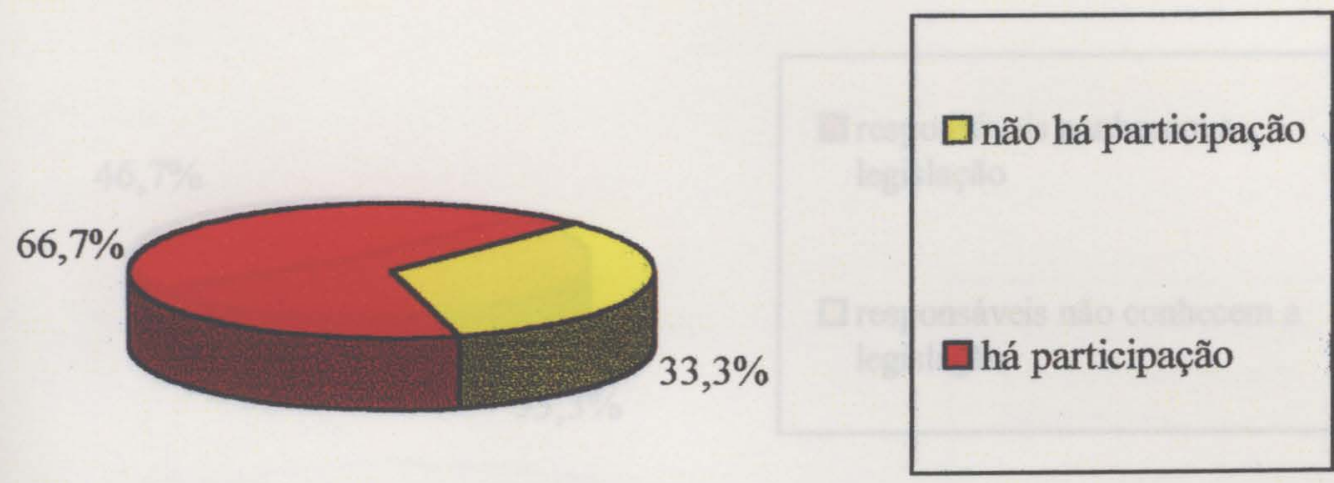

Figura 25: Participação da comunidade nos projetos

\section{Abordagem sobre a Ocupação Irregular das Áreas de Mananciais}

A grande maioria dos projetos (93,3\%), de acordo com os dados obtidos pelo questionário, abordam a problemática da ocupação irregular em áreas de mananciais. Apenas para um projeto $(6,7 \%)$ foi colocado que esta questão não é enfocada.

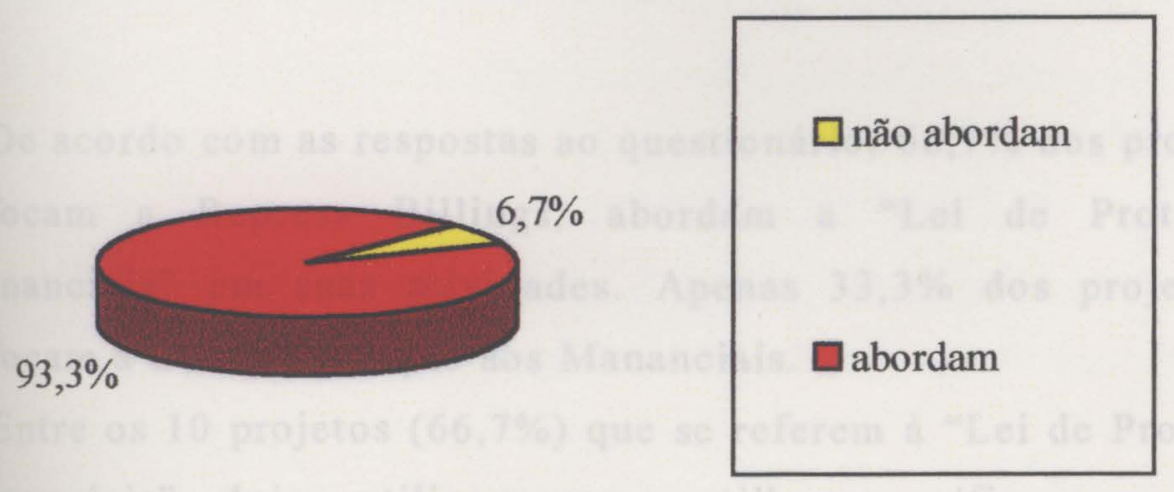

Figura 26: Abordagem pelos projetos da ocupação irregular das áreas de mananciais 


\section{Conhecimento Acerca da Legislação referente a Proteção de Mananciais}

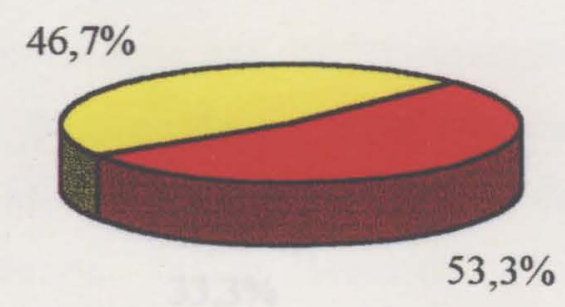

responsáveis conhecem a

legislação

responsáveis não conhecem a legislação

Figura 27: Conhecimento dos responsáveis pelos projetos sobre a legislação de proteção aos mananciais

Apesar de em 93,3\% (item 4.5) dos projetos a ocupação irregular das áreas de mananciais ser levantada, apenas 53,3\% dos responsáveis por estes projetos conhecem a legislação específica sobre o assunto. Como legislação específica, a única citada nos questionários foi a "Lei de Proteção aos Mananciais”.

Lei de Proteção de Mananciais como Subsídio para as Atividades dos Projetos.

De acordo com as respostas ao questionário, $66,7 \%$ dos projetos que enfocam a Represa Billings, abordam a "Lei de Proteção aos Mananciais" em suas atividades. Apenas 33,3\% dos projetos não enfocam a Lei de Proteção aos Mananciais.

Entre os 10 projetos $(66,7 \%)$ que se referem à "Lei de Proteção aos Mananciais", dois utilizam uma cartilha específica como material instrucional sobre o assunto editada e distribuída nas escolas pela organização não governamental MOVIMENTO EM DEFESA DA VIDA DO GRANDE ABC (1999); dois outros realizam palestra específica 
feita por técnicos da área ambiental e um utiliza uma apostila elaborada pelo coordenador do projeto a partir do texto oficial da legislação; os outros não mencionaram a forma de utilização.

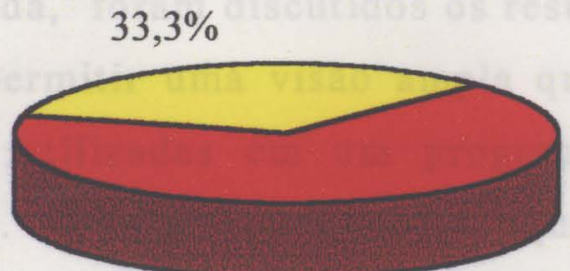

$66,7 \%$
DProjetos que abordam a Lei de Proteção aos Mananciais

$\square$ Projetos que não abordam a Lei de Proteção aos Mananciais

Figura 28: Abordagem da Lei de Proteção aos Mananciais pelos projetos que enfocam a Represa Billings. 


\section{DISCUSSÃo}

A principal contribuição que se pretendeu dar com este trabalho foi estabelecer um panorama da Educação Ambiental desenvolvida nas escolas públicas da região de mananciais da Represa Billings, a fim de proporcionar um direcionamento para futuras ações.

Sendo assim, esta discussão foi encaminhada neste sentido e devido à grande quantidade de informações obtidas pela metodologia utilizada, foram discutidos os resultados considerados mais relevantes para permitir uma visão ampla que possibilite formular estratégias a serem utilizadas em um programa de Educação Ambiental para a região. Esperamos, também, que os dados levantados com este diagnóstico e não discutidos, possam servir de referência para outros estudos mais aprofundados relativos a alguns aspectos específicos.

As recomendações de diversos documentos e textos oficiais sempre destacam a importância do sistema escolar de ensino para a prática da Educação Ambiental, principalmente incluindo nas atividades pedagógicas uma análise dos problemas ambientais locais (SÃO PAULO 1997a; VIANNA 1996).

As escolas, na sua prática cotidiana, vivenciam os problemas trazidos por alunos, professores e funcionários, refletindo assim, os problemas da comunidade onde estão inseridas. Devido a isso, apresentam grande potencial para atuarem como um pólo importante de sensibilização e mobilização para as questões ambientais locais (WEID 1997).

Os resultados obtidos com este trabalho indicam que este potencial não vem sendo devidamente explorado no universo das escolas públicas estaduais analisadas.

De acordo com os dados da Figura 1(pag.33), das 58 escolas analisadas neste trabalho, apenas $24,1 \%$ apresentam projetos de Educação Ambiental que focalizam a problemática da Represa Billings. Tal resultado surpreende visto que tais escolas estão 
localizadas próximas ou em áreas de mananciais deste reservatório e que a degradação da Represa Billings pode ser considerado um dos principais problemas ambientais da região de estudo.

Vale lembrar que foi considerado como "Projeto de Educação Ambiental", qualquer conjunto-de atividades envolvendo as questões ambientais que como tal foi definido pelos seus responsáveis, independente de sua estrutura e organização.

A situação torna-se mais preocupante quando se constata que das 14 escolas que tem projetos de Educação Ambiental sobre a Represa Billings e que representam os mencionados $24,1 \%$, apenas 9 têm os projetos atualmente em desenvolvimento (Tabela 4; pag.42).

Numa análise mais detalhada dos projetos que envolvem a Represa Billings, também foi verificado que apenas $40 \%$ são específicos sobre o reservatório sendo que os outros incluem a Represa Billings juntamente com outras questões ambientais (Figura 23; pag.63).

Se levarmos em consideração que as 58 escolas analisadas respondem pelo atendimento a cerca de 80.000 alunos, na sua maioria residentes em áreas de mananciais ou próximas e que, portanto, um número muito reduzido destes alunos estão sendo atingidos por programas de Educação Ambiental (Tabela 2; pag.35), percebe-se a importância de se implementar propostas mais efetivas para esta região.

Quando se observa os mapas constantes nos Anexos 6, 7 e 8 do presente estudo, pode-se ter uma dimensão da situação atual da Educação Ambiental nas escolas estaduais da região pois, partindo-se de 58 escolas analisadas e passando-se por 33 escolas que apresentam projetos de Educação Ambiental, chega-se ao restrito número de 9 escolas que atualmente estão desenvolvendo atividades de Educação Ambiental relacionadas à Represa Billings.

As 14 escolas já mencionadas, apresentam no conjunto, 15 projetos de Educação Ambiental relativos à Represa Billings, sendo 
que 10 destes projetos são conduzidos através de parcerias, como pode ser observado na Tabela 9(pag.52). Além disso, pode-se verificar que dos 9 projetos relacionados à Represa Billings, atualmente em desenvolvimento, 7 são conduzidos através de parcerias. Tais resultados demonstram que as parcerias parecem ser um fator importante para que as atividades de Educação Ambiental sejam implementadas nas escolas.

WEID (1997), em trabalho realizado junto a escolas da rede municipal de ensino da cidade do Rio de Janeiro, visando a implantação de projetos de Educação Ambiental, entre outros resultados, concluiu que o estabelecimento de parcerias é um mecanismo importante para garantir a continuidade dos projetos, por produzir estímulos e pressão para que os mesmos não sejam interrompidos.

Quando questionadas à respeito da forma de parceria, os resultados apresentados na Tabela 8 (pag.52) demonstram que o apoio financeiro ou repasse direto de verbas às escolas não é o fator que leva à manutenção destes projetos, pois nenhuma das escolas que tem projetos em parceria relacionados à Represa Billings, mencionou receber apoio financeiro da instituição parceira. A manutenção destes projetos parece estar relacionada ao fornecimento, pela instituição parceira, de apoio técnico, recursos didáticos e humanos.

Reforçando esta conclusão, a análise do projeto "Água Limpa Viva a Vida" (Anexo 5), conduzido pelo Serviço Municipal de Água e Saneamento de Santo André, em parceria com 5 escolas estaduais localizadas naquele município, demonstrou que essa parceria baseia-se principalmente num acompanhamento continuo do projeto fornecendo ao professor uma assessoria permanente na condução das atividades, além de programas de capacitação.

WEID (1997), no trabalho já mencionado anteriormente, também destacou em sua experiência a importância fundamental de se oferecer uma assessoria através de apoio técnico-pedagógico permanente 
durante o desenvolvimento do projeto, permitindo através deste acompanhamento a consolidação dos projetos nas escolas.

Nas escolas que não têm projetos de Educação Ambiental, uma das principais causas mencionadas como determinante deste fato, foi a falta de pessoal capacitado e de conhecimento técnico na área, sendo que a ausência de apoio financeiro é o fator que parece ter menos relevância para a implantação de tais projetos, como pode ser observado na Figura 2(pag.36).

Até mesmo nas escolas que têm projetos de Educação Ambiental, a falta de capacitação dos professores foi citada como uma das principais dificuldades encontradas para o desenvolvimento destes projetos.

Tais dados reforçam a importância do estabelecimento de parcerias ou programas que estejam baseados principalmente no apoio técnico aos profissionais da escola.

Outra dificuldade igualmente importante nestas escolas, é a inexistência de horário remunerado, fora do horário de aulas, para os profissionais envolvidos poderem dedicar-se ao projeto (Tabela 11; pag.62).

Um dado que chama a atenção é o de que $22,7 \%$ das escolas analisadas, atribuíram a ausência de projetos de Educação Ambiental ao fato do tema ser abordado juntamente com outros, dentro dos temas transversais (Figura 2; pag.36).

A transversalidade é uma forma de organizar o trabalho didático, onde os conteúdos dos chamados "temas transversais" são incorporados nas áreas já existentes e no trabalho educativo da escola. Os Temas Transversais correspondem a questões importantes, urgentes e presentes, sob várias formas, na vida cotidiana, cuja discussão deve possibilitar a compreensão e a crítica da realidade. Dentro dos Parâmetros Curriculares Nacionais- PCNs, são elencados como temas transversais as questões relativas à Ética, Pluralidade Cultural, Meio Ambiente, 
Saúde, Orientação Sexual, Trabalho e Consumo e Uso das Tecnologias da Comunicação. De acordo com as orientações para o tratamento dos temas transversais, estes podem ser trabalhados dentro de "projetos", sendo definido como projeto "uma série de atividades organizadas e direcionadas, planejadas para uma meta preestabelecida, cujo resultado é observável" (MINISTÉRIO DA EDUCAÇÃO E DO DESPORTO 1997c).

Aparentemente, a inclusão da Educação Ambiental nos temas transversais deveria estimular a realização de projetos, porém, de acordo com as informações dos professores, esta forma de tratamento faz com que não exista, nestas escolas, um projeto específico sobre Educação Ambiental, uma vez que a temática ambiental é abordada dentro de um conjunto de outros temas relevantes indicados nos $\mathrm{PCNs}$.

Ainda no que se refere à capacitação, quando se faz uma análise do perfil dos responsáveis pelos projetos nas escolas, verifica-se que a grande maioria, ou seja, cerca de $90 \%$, não têm formação específica em Educação Ambiental (Figura 6; pag.39). Isto talvez explique o fato de $46,9 \%$ destes responsáveis desconhecerem totalmente todos os documentos referenciais que norteiam a Educação Ambiental e também que documentos importantes como a Agenda 21, as Recomendações de Tbilisi e a Carta de Belgrado, sejam do conhecimento de uma minoria destes responsáveis (Figura 7; pag.40).

Quando se verifica que a porcentagem dos responsáveis que não conhecem os documentos oficiais referenciais é bem menor entre os que coordenam os projetos que enfocam a Represa Billings (Tabela 3; pag.41) e sabendo-se que a maioria destes projetos são desenvolvidos através de parcerias (Tabela 7; pag.51), pode-se supor que exista alguma relação de causa e efeito entre estes fatos.

Os resultados relativos à capacitação aqui discutidos, são compatíveis e, por assim dizer, se refletem naqueles observados para 
os textos e documentos que subsidiam os projetos. Como pode ser verificado na Tabela 5 (pag.48), 60\% dos projetos que não enfocam a Represa Billings, não são subsidiados por nenhum texto ou documento oficial, enquanto que o mesmo só acontece com $26,7 \%$ dos projetos que enfocam o reservatório. Comparando-se estes resultados com aqueles relativos ao conhecimento dos textos pelos responsáveis (Tabela 3; pag.41) verifica-se que tais resultados parecem estar correlacionados.

Outra associação interessante a ser feita é aquela que se refere à própria temática dos projetos e a capacitação do seu coordenador. $O$ conhecimento relativo aos textos e documentos oficiais devem conduzir à incorporação dos princípios da Educação Ambiental, entre eles a recomendação de uma abordagem nos projetos, de uma temática ambiental local. Sendo assim, não é de se surpreender que os projetos onde os coordenadores têm maior capacitação estejam voltados para um importante problema ambiental local, qual seja a degradação da Represa Billings.

Ainda no que se refere ao perfil dos responsáveis pelos projetos nas escolas, vale mencionar que a maioria exerce na escola a função de professor $(59,4 \%)$ e são graduados $(78,1 \%)$ principalmente em Pedagogia $(40,7 \%)$ e Ciências e Biologia $(31,1 \%)$, como pode ser verificado nas Figuras 3, 4 e 5 (pags.37, 38 e 39).

A Política Nacional de Educação Ambiental, instituída pela Lei ${ }^{\circ}$ 9.795/99, determina que a Educação Ambiental não deve ser implantada como uma disciplina específica no currículo escolar. No Art. $4^{\circ}$ da referida lei é estabelecido que seu tratamento deve ser interdisciplinar, multidisciplinar e até transdisciplinar.

A análise geral dos projetos demonstrou que a maioria tem caráter multidisciplinar ( $85,7 \%$ ) (Figura 9; pag.44).

Vale mencionar, que no item 3.4 do questionário (pag.A-7), que se refere ao enfoque dado ao projeto em termos do envolvimento de 
disciplinas, inicialmente foram oferecidas as opções "disciplinar", "multidisciplinar", "interdisciplinar" e "transdisciplinar".

Porém, após o pré-teste e, também, durante as conversas informais mantidas durante a condução da pesquisa, foi verificado que os professores apresentam uma grande dificuldade em distinguir conceitualmente os três últimos termos. Sendo assim, optou-se por manter apenas um destes termos, devido à dificuldade que os professores tiveram em diferenciar multidisciplinaridade, interdisciplinaridade e transdisciplinaridade. Por si só, esta é uma constatação que merece atenção pelas implicações que tem com a abordagem metodológica da Educação Ambiental nas escolas.

Se entendermos por multidisciplinar o trabalho conduzido simultaneamente por várias disciplinas, sem ressaltar as relações que podem existir entre elas; por interdisciplinar, o trabalho onde existe uma cooperação ativa entre várias disciplinas, com intercâmbio para enriquecimento de um tema; e por transdisciplinar uma convergência entre diversas disciplinas para uma unificação conceitual, verificamos que a multidisciplinaridade é a base da interdisciplinaridade e da transdisciplinaridade (DIAS 1994; JAPIASSU 1976). Devido a isto optou-se por manter, entre os três, apenas o termo "multidisciplinar" visando minimizar a obtenção de dados incorretos. Porém, um estudo mais aprofundado se faz necessário para caracterizar de forma precisa o aspecto da interação entre disciplinas.

Os projetos que enfocam a Represa Billings são mais abrangentes pois a maioria envolve todas as séries da escola (73.3\%) e também a comunidade $(66,7 \%)$, enquanto que apenas $50 \%$ dos projetos que não enfocam a Represa Billings abrangem todas as séries e $35 \%$ envolvem a comunidade (Figuras 10 e 11 ;pag.45).

Estes dados parecem indicar que os projetos que enfocam a Represa Billings estão melhor articulados e aproximam-se mais das recomendações oficiais não só no que se refere à temática, como 
também por envolverem de maneira mais significativa a comunidade escolar e de entorno.

Ainda com relação a análise geral dos projetos, verificou-se que a maioria obedece um planejamento $(93,4 \%)$, principalmente anual $(38,1)$ ou bimestral $(31,4 \%)$ (Figuras 13 e $14 ;$ pag.49).

No que se refere a atuação do poder público, a Tabela 2 (pag.35) indica que a implementação da Educação Ambiental nas escolas estaduais, sofre influência dos municípios. De acordo com os dados, observa-se que nos municípios de Ribeirão Pires e São Bernardo do Campo, cerca de $50 \%$ das escolas analisadas não apresentam projetos de Educação Ambiental. Já no município de Santo André, apenas $14,3 \%$ das escolas analisadas não têm projeto sendo que 71,4\% têm projeto específico sobre a Represa Billings. Conforme verificado junto a estas escolas, estes projetos fazem parte de uma parceria estabelecida através de iniciativa da prefeitura local que tem disponibilizado recursos para condução do projeto "Água Limpa Viva Vida", já mencionado nesta discussão.

Ainda no que se refere ao poder público, é interessante salientar que em nenhum momento deste estudo a Secretaria do Meio Ambiente do Estado de São Paulo ou sua Coordenadoria de Educação Ambiental - CEAM, foram mencionadas diretamente, nem como instituições parceiras (Tabela 9; pag.52), nem como fonte motivadora dos projetos (Tabela 6; pag.50), o que pode indicar uma falta de sintonia entre os diversos setores do poder público estadual no que se refere à implementação da Educação Ambiental nas escolas da rede, pelo menos na região analisada.

Tal constatação pode significar, ainda, uma falta de efetividade ou visibilidade das ações implementadas pela CEAM.

Uma das principais funções da CEAM é coordenar e garantir a integração das atividades de Educação Ambiental nas escolas da rede pública e particular e entre os diversos setores organizados da sociedade civil (SÃO PAULO 1998c). 
Durante os anos de 1995 e 1998, a CEAM desenvolveu uma série de ações voltadas para as escolas, visando atingir professores e alunos. Através de uma estratégia de atuação entre a Secretaria do Meio Ambiente e a Secretaria da Educação, foram realizadas diversas atividades incluindo, entre outras, reuniões técnicas com os delegados das Delegacias de Ensino da Grande São Paulo para discutir a metodologia a se usar no processo de capacitação de agentes multiplicadores para a rede de ensino; encontros e workshops para estabelecer estratégias de ações para o desenvolvimento da Educação Ambiental na rede de ensino; seminários, cursos, encontros técnicos e oficinas de orientação técnica destinadas a professores, coordenadores e assistentes técnicos pedagógicos de escolas públicas e particulares visando fornecer subsídios para planejar e implantar atividades de Educação Ambiental nas escolas; pesquisa diagnóstico das experiências de Educação Ambiental para análise dos conceitos, levantamento das expectativas e necessidades dos educadores (SÃO PAULO 1998c, SABIÁ 1998).

Outra atividade da CEAM cujos reflexos deveriam ser sentidos nas escolas públicas, foi a implantação, a partir de 1996, dos Núcleos Regionais de Educação Ambiental, cujo programa tem produzido materiais didáticos, entre eles dois mil kits didáticos, contendo material de divulgação e informação sobre mananciais para distribuição no sistema formal de ensino da região do $\mathrm{ABC}$ (SÃO PAULO 1998c).

É, portanto, bastante interessante verificar que no âmbito das escolas analisadas, nenhuma menção ou associação com a CEAM tenha sido verificada.

As próprias Delegacias de Ensino apareceram como tendo uma atuação pouco significativa como fonte motivadora dos projetos junto às escolas (Tabela 6; pag.50).

Deve-se lembrar, entretanto, que entre os quatro coordenadores de projetos que têm capacitação específica em Educação Ambiental 
$(12,5 \%)$, três realizaram curso de aperfeiçoamento através da Delegacia de Ensino de São Bernardo do Campo (Figura 6; pag.39).

De acordo com JACOBI (1998) a "educação ambiental que tem sido desenvolvida no país é muito diversa e a presença dos órgãos governamentais como articulador, coordenador e promotor de ações é ainda muito restrita".

Os resultados observados com o presente diagnóstico reforçam esta constatação, pelo menos no que se refere aos órgãos do poder público estadual.

Já as prefeituras municipais aparecem de forma significativa como fontes motivadoras dos projetos (Tabela 6; pag.39) e também como instituições parceiras de um número considerável de iniciativas (Tabela 9; pag.52).

A única menção relevante relacionada diretamente ao poder público estadual foi a indicação do "Programa Estadual de Educação Ambiental" como o segundo documento mais utilizado para subsidiar os projetos (Tabela 5; pag.48).

Também significativa é a participação de empresas, fundações privadas e ONGs, uma vez que algumas ações geradas ou apoiadas por estes setores puderam ser detectadas. Os resultados da Tabela 6 (pag.50) indicam que um número razoável de projetos foram motivados por empresas e fundações privadas dos mais diversos tipos, com as quais algumas escolas mantêm projetos em parceria (Tabela 9; pag.52).

A análise dos aspectos metodológicos demonstrou uma grande diversidade de concepções e formas de condução dos projetos, com utilização de diversas técnicas pedagógicas (Figura 17, Figura 18, Tabela 10; pags.55, 56 e 59).

Observa-se uma tendência para desenvolvimento de atividades que se concentram na própria escola (Figura 17; pag.55) ao longo de todo o ano letivo (Figura 18; pag.56). 
Entre as técnicas pedagógicas mais citadas estão o estudo de texto, confeç̧ão de material didático, discussão em grupo e exposições, sem que se tenha observado grandes disparidades quando foram comparados os projetos que envolvem a Represa Billings e os que não envolvem (Tabela 10; pag.59).

Qualquer conclusão a respeito dos aspectos metodológicos dos projetos mostrou-se muito complexa diante da técnica de coleta de dados utilizada, pois muitas escolas não deram respostas às questões relacionadas a este aspecto, demonstrando a necessidade de um estudo mais especifico sobre o assunto.

A mesma dificuldade foi verificada no "Levantamento Nacional de Projetos de Educação Ambiental" que observou um baixo índice de respostas sobre questões metodológicas, avaliação dos projetos e divulgação da Agenda 21, entre outros, sugerindo um estágio ainda inicial da Educação Ambiental no país ou ainda que o público alvo não foi receptivo à pesquisa (MINISTÉRIO DO MEIO AMBIENTE 1997).

Quanto à temática dos projetos, os três temas mais abordados foram a Poluição da Água, Saúde Pública e Poluição do Ar (Figura 19; pag.57), o que pode indicar uma preocupação com temas relacionados a realidade mais próxima, mesmo nos projetos que não tratam especificamente da Represa Billings. Este aspecto é importante pois demonstra que a orientação dos projetos, a despeito dos seus problemas estruturais, tem sido no sentido de discutir problemas ambientais locais, como determinam os preceitos básicos da Educação Ambiental.

O "Levantamento Nacional de Projetos de Educação Ambiental" também demonstrou que os temas mais abordados nos projetos em andamento no país se relacionam à percepção de problemas locais, relacionando-se com preocupações comunitárias, situação esta que se reflete na Educação Ambiental no contexto escolar (MINISTÉRIO DO MEIO AMBIENTE 1997). 
Observou-se que a temática dos projetos está relacionada aos principais objetivos verificados, pois de acordo com os dados da Figura 12 (pag.47) verifica-se que os principais objetivos referem-se à sensibilização dos estudantes e comunidade a respeito de aspectos relacionados ao meio ambiente.

No tocante à forma de avaliação utilizada, a diversidade das respostas demostrou claramente que a avaliação dos projetos de Educação Ambiental necessita de uma metodologia específica. Os resultados apresentados na Figura 20 (pag.60) mostram que as formas de avaliação citadas não estabelecem vínculo entre os objetivos propostos e os resultados obtidos.

Conforme DIETZ e NAGAGATA (1997) enfatizam, em trabalho de Educação Ambiental realizado com comunidades, a avaliação é uma fase crucial de um programa educacional eficaz e uma vez estabelecidos os objetivos, o projeto deve ser planejado de forma a incluir a avaliação dos resultados de acordo com estes objetivos.

TABANEZ e col. (1997) também salientam que a metodologia de avaliação adotada é de grande relevância para mensurar a efetividade das diferentes estratégias educacionais utilizadas em trabalhos de Educação Ambiental.

A falta de critérios de avaliação ficou bem caracterizada quando se procurou analisar os resultados citados para os diferentes projetos. A análise deste item tornou-se complicada uma vez que sem critérios de avaliação definidos, ficou claro que houve dificuldades em verificar os resultados obtidos. Como pode ser observado na Figura 22 (pag.61), os resultados mencionados são qualitativos e não refletem de maneira clara as diferenças observadas entre a situação anterior e posterior ao estabelecimento dos projetos.

A análise relativa aos projetos que envolvem a Represa Billings, demonstrou que a ocupação irregular das áreas de mananciais é abordada quase que pela totalidade dos projetos (Figura 26; pag.65). 
Porém os resultados foram um tanto contraditórios no que se refere ao conhecimento da "Lei de Proteção aos Mananciais" pelos coordenadores dos projetos: quando a questão foi específica e direta sobre o assunto, $53,3 \%$ dos responsáveis disseram conhecer tal lei (Figura 27; pag.66), no entanto, em questão onde a "Lei de Proteção aos Mananciais" foi mencionada juntamente com outros documentos oficiais, $71,5 \%$ dos coordenadores disseram ter conhecimento deste texto, sendo inclusive o documento mais citado entre os demais (Tabela 3; pag.41). Na própria Tabela 3, também é possível verificar que mesmo entre os responsáveis por projetos que não enfocam a Represa Billings, um número significativo conhece o documento $(38,9 \%)$.

De acordo com os dados da Figura 28 (pag.67) e Tabela 5 (pag.48), a "Lei de Proteção aos Mananciais" tem sido utilizada como subsídio em $66,7 \%$ dos projetos que enfocam a Represa Billings. A Tabela 5 também indica que em $40,0 \%$ dos projetos que não enfocam a Represa Billings, esta lei é citada como um dos textos oficiais utilizados como subsídios, ficando entre os mais citados.

Estes dados indicam que a "Lei de Proteção aos Mananciais" tem subsidiado os projetos de Educação Ambiental desenvolvidos pelas escolas analisadas.

Conforme foi detectado através de conversas informais com os professores, esta situação pode ser em parte atribuída à iniciativas como a da organização não governamental "Movimento em Defesa da Vida do Grande $A B C "$ que editou e distribuiu entre as escolas da região, uma cartilha (MOVIMENTO EM DEFESA DA VIDA DO GRANDE ABC 1999), financiada pelo Fundo Estadual de Recursos Hídricos - FEHIDRO, onde a problemática referente às áreas de mananciais e as leis de proteção destas áreas são discutidas de forma acessível ao público leigo. 
Além dos dados levantados pelos questionários, as conversas informais com os professores e visitas às escolas, permitiram apreender outros aspectos relevantes.

Alguns autores têm enfatizado a importância de se privilegiar o conceito de "Bacia Hidrográfica" como unidade mínima de estudo ecológico (TUNDISI 1992; SÉ 1999).

Dentro desta perspectiva, vários programas e projetos de Educação Ambiental vêm sendo desenvolvidos com base no estudo das bacias hidrográficas de suas regiões, visando compor um quadro sobre os processos de degradação da qualidade das águas e possibilidades de reversão dessas alterações (SANTOS RA 1998; SANTOS SAM 1998; RAVAGNANI 1999; SÉ 1999).

Conforme foi observado na área desta pesquisa, os trabalhos relacionados com a degradação da qualidade das águas, têm como principal base de estudo as Äreas de Proteção e Recuperação dos Mananciais - APRMs, sendo este o principal conceito trabalhado e não o de bacia hidrográfica. Este fato talvez seja devido à grande complexidade e extensão territorial da zona hidrográfica que compõe o sistema de abastecimento e drenagem da Região Metropolitana de São Paulo, da qual a Bacia do Reservatório Billings faz parte. Até porque, nesta região, os próprios limites da bacia hidrográfica e das áreas de proteção de mananciais muitas vezes se confundem.

Outro aspecto interessante, é que as áreas onde estão localizadas a maioria das escolas pesquisadas, estão incluídas no "Plano Emergencial de Recuperação dos Mananciais da Região Metropolitana de São Paulo", aprovado pelo Conselho Estadual do Meio AmbienteConsema e pelo Conselho Estadual de Recursos Hídricos-CRH, através do Decreto $\mathrm{n}^{0} 43.022$, de 07/04/98. Este plano prevê ações e obras emergenciais que devem ser realizadas, a curto prazo, em áreas já degradadas. Estas obras visam o controle da poluição das águas, contenção da erosão, drenagem de águas pluviais, revegetação e outras intervenções. Apesar da importância deste plano, os 
professores, assim como a maior parte da população, desconhecem sua existência, embora sua execução deva ser acompanhada através da implantação de um Sistema de Fiscalização Integrada e do desenvolvimento de campanhas de Educação Ambiental, conforme deliberação do próprio Consema.

Também ficou bem caracterizado que os professores desconhecem as diversas instâncias de articulação e representação social no gerenciamento dos recursos hídricos, tais como os comitês e subcomitês de bacias. 


\section{CONCLUSÕES}

Os dados obtidos com este trabalho permitiram as seguintes constatações:

- Nas escolas analisadas, foi observado um número reduzido de projetos que focalizam a problemática da Represa Billings.

- das 58 escolas analisadas, 33 têm projetos de Educação Ambiental, sendo que em apenas 15 destas escolas os projetos enfocam a problemática da degradação da Represa Billings e somente 9 destes projetos estão atualmente em desenvolvimento.

- entre os 9 projetos que enfocam a Represa Billings e que estão atualmente em desenvolvimento, 7 são executados através de parcerias principalmente com as prefeituras locais.

- os resultados sugerem que a forma de parceria que leva à manutenção dos projetos em andamento, é a que oferece apoio técnico através da capacitação dos professores e acompanhamento permanente dos projetos até sua consolidação.

- a falta de capacitação específica em Educação Ambiental é grande entre os professores, tanto das escolas que têm projetos de Educação Ambiental como nas que não têm.

- as diversas ações em Educação Ambiental desenvolvidas por órgãos do setor público como as Secretarias de Estado do Meio Ambiente e da Educação, não atingem ou não se consolidam nas escolas.

- foram detectadas falhas estruturais importantes nos projetos, principalmente aquelas associadas à metodologia de avaliação dos resultados.

- A nova "Lei de Proteção aos Mananciais" tem sido utilizada como subsídio para um número significativo dos projetos analisados. 
Diante destas constatações pode-se concluir que as futuras ações de Educação Ambiental nas escolas da região devem ser estabelecidas de forma a priorizar:

1. A criação de programas que envolvam, além da capacitação dos profissionais das escolas, um acompanhamento permanente dos projetos pelo menos até sua consolidação.

2. O desenvolvimento de metodologias específicas para a Educação Ambiental, principalmente referentes à avaliação dos resultados.

3. O fortalecimento de parcerias, principalmente com as prefeituras locais. ONGs e as empresas e instituições privadas.

4. A ampliação das discussões relativas a recuperação e proteção da Represa Billings. 


\section{REFERÊNCIAS BIBLIOGRÁFICAS}

Aguiar RAR. Direito do meio ambiente e participação popular. Brasília: IBAMA; 1994.

Becker F. Da ação à operação: o caminho da aprendizagem em J. Piaget e P. Freire. $2^{\circ}$ ed. Rio de Janeiro: DP\&A Editora e Palmarinca; 1997.

Castilho JC. História Condensada da Represa Billings. Diadema: Prefeitura do Município de Diadema; 1998.

CETESB- Companhia de Tecnologia de Saneamento Ambiental. Relatório de Qualidade das Águas Interiores do Estado de São Paulo - 1996. São Paulo; 1998. (CETESB/Série Relatórios).

Dias GF. Atividades interdisciplinares de educação ambiental. São Paulo: Global/Gaia (co-edição); 1994.

Dietz LAH, Nagagata EY. Programa de conservação do Mico-leãodourado: atividades de educação comunitária para conservação da Mata Atlântica no Estado do Rio de Janeiro. In: Padua SM, Tabanez MF, organizadores. Educação Ambiental - caminhos trilhados no Brasil. 1' ed. Brasília: Instituto de Pesquisas Ecológicas; 1997. p.7388.

Freire P. Conscientização; teoria e prática da libertação; uma introdução ao pensamento de Paulo Freire. São Paulo: Cortez \& Moraes; 1979a.

Freire P. Conscientizar para libertar. In: Torres CAN, organizador. A práxis educativa de Paulo Freire. São Paulo: Loyola; 1979b. p.93104.

Freire P. Pedagogia do oprimido. $6^{\circ}$ ed. Rio de Janeiro: Paz e Terra; $1979 \mathrm{c}$.

Gil AC. Métodos e técnicas de pesquisa social. $1^{2}$ ed. São Paulo: Atlas; 1991.

Gil AC. Como elaborar projetos de pesquisa. $3^{\circ}$ ed. São Paulo: Atlas; 1996.

Grün M. Ética e Educação Ambiental: a conexão necessária. Campinas: Editora Papirus; 1996. 
Guimarães M. A dimensão ambiental na Educação. Campinas: Editora Papirus; 1995.

Höeffel JL, Viana RM, Padua SM. A consciência ambiental e os 5 "es". In: Cascino F, Jacobi P, Oliveira JF, organizadores. Educação, meio ambiente e cidadania. 1 " ed. São Paulo: Secretaria do Meio Ambiente, 1998.p.23-26.

Hübner MM. Guia para elaboração de monografias e projetos de dissertação de mestrado e doutorado. $1^{*}$ ed. São Paulo: Pioneira; 1998.

Jacobi P. Educação ambiental e cidadania. In: Cascino F, Jacobi $P$, Oliveira JF, organizadores. Educação, meio ambiente e cidadania. 1' ed. São Paulo: Secretaria do Meio Ambiente, 1998.p.11-14.

Japiassu H. Interdisciplinaridade e patologia do saber. Rio de Janeiro: Imago; 1976.

Lakatos EM, Marconi MA. Fundamentos de metodologia científica. $3^{*}$ ed. São Paulo: Gaia; 1996.

Lopes NN. Legislação Ambiental e Cidadania. Revista Viva 1993; $1(1): 15-16$.

Manzochi LH. Impressões de Tessalonique. Educador Ambiental $1998 ; 5(17): 1-3$.

Ministério da Educação e do Desporto. Educação Ambiental. Brasília; 1997 a.

Ministério da Educação e do Desporto. PRONEA - Programa Nacional de Educação Ambiental. Brasília; 1997b.

Ministério da Educação e do Desporto. Secretaria de Educação Fundamental. Parâmetros Curriculares Nacionais. Brasília; $1997 \mathrm{c}$.

Ministério do Meio Ambiente. Levantamento Nacional de Projetos de Educação Ambiental ( relatório). Brasília; 1997.

Ministério do Meio Ambiente. Propostas de Diretrizes Para a Implantação da Política Nacional de Educação Ambiental. Brasília; 1999. Disponível em <URL: http://www.bdt.org.br/educacao/lei/ diretrizes $>$ [2000 fev 02] 
Moreno A. Conflitos Ambientais no Reservatório Billings: uma análise da Lei de Proteção aos Mananciais e de sua expansão urbana. São Paulo; 1994 [Tese de Mestrado em Geografia FFLCH/USP].

Movimento em Defesa da Vida do Grande ABC. Saiba como defender nossa água. São Bernardo do Campo; 1999. [Cartilha integrante do projeto "Reservatório Billings: Potável por Inteiro" - MDV]

Pelicioni AF. Educação Ambiental na escola: um levantamento de percepções e práticas de estudantes de primeiro grau a respeito de meio ambiente e problemas ambientais. São Paulo; 1998. [Tese de Mestrado - Faculdade de Saúde Pública da USP]

Philippi Junior A, Ogera RC, Kudzielicz E, Redolfi SCS. Planejamento Estratégico Para Gestão Ambiental De Município: A Experiência De São Paulo. [trabalho apresentado no $20^{\circ}$ Congresso Brasileiro de Engenharia Sanitária e Ambiental; 1999 maio 10-14; Rio de Janeiro/RJ].

Ravagnani AS. Desenvolvimento de programas de educação ambiental utilizando a bacia hidrográfica como método de abordagem de ensino. Rio Claro; 1999. [Tese de Mestrado - Centro de Estudos Ambientais/UNESP]

Sabiá IR. A escola e a educação ambiental: relato de experiências. In: Cascino F, Jacobi P, Oliveira JF, organizadores. Educação, meio ambiente e cidadania. $1^{*}$ ed. São Paulo: Secretaria do Meio Ambiente, 1998.p.35-37.

Santos KC. Avaliação de um projeto de educação ambiental desenvolvido em escolas públicas do ensino fundamental em São Carlos-SP. São Carlos; 1999. [Tese de Mestrado - Programa de PósGraduação em Ecologia e Recursos Naturais/UFSCAR].

Santos RA. Educação e a conservação da bacia do Rio Coxipó-MT: uma abordagem no ensino fundamental. Cuiabá; 1998. [ Tese de Mestrado - Instituto de Educação da Universidade Federal de Mato Grosso].

Santos SAM. Bacia hidrográfica e qualidade da água: as experiências de uma década de programas em educação ambiental desenvolvidos no CRHEA/CDCC-USP. São Carlos; 1998. [ Tese de Mestrado - Escola de Engenharia de São Carlos/USP].

São Paulo (Estado). Empresa Metropolitana de Planejamento da Grande São Paulo - EMPLASA. Secretaria de Estado dos Negócios 
Metropolitanos. Região Metropolitana de São Paulo: proteção aos mananciais - legislação. São Paulo; 1984.

São Paulo (Estado). Secretaria do Meio Ambiente. Secretaria da Educação. Programa de Educação Ambiental do Vale do Ribeira: legislação e meio ambiente. São Paulo; 1990.

São Paulo (cidade). Secretaria Municipal do Verde e do Meio Ambiente. Agenda 21 local: Compromisso do Município de São Paulo. São Paulo; 1996a.

São Paulo (Estado). Secretaria do Meio Ambiente. Quadro situacional das Áreas de Proteção aos mananciais na bacia do Reservatório Billings. São Paulo; $1996 \mathrm{~b}$.

São Paulo (Estado). Secretaria do Meio Ambiente. Agenda 21;Conferência das Nações Unidas sobre meio ambiente e desenvolvimento. Documentos Ambientais. São Paulo; 1997 a.

São Paulo (Estado). Secretaria do Meio Ambiente. Termo de referência para o plano de recuperação ambiental da bacia Billings. São Paulo; 1997 b.

São Paulo (Estado). Secretaria do Meio Ambiente. Tratados e organizações ambientais em matéria de meio ambiente. São Paulo; $1997 \mathrm{c}$.

São Paulo (Estado). Secretaria do Meio Ambiente. Lei Estadual n9.866/97: uma nova política de mananciais. São Paulo; 1998a.

São Paulo (Estado). Secretaria do Meio Ambiente. Coordenadoria de Educação Ambiental. Programa Estadual de Educação Ambiental. São Paulo; 1998 b.

São Paulo (Estado). Secretaria do Meio Ambiente. Coordenadoria de Educação Ambiental. Educação Ambiental. São Paulo; 1998 c.

Sato M. Educação Ambiental: o que diz a literatura. Ambiente 1994; $8(1): 35-37$.

Sé JAS. Educaçāo ambiental nas bacias hidrográficas do Rio Monjolinho e do Rio Chibarro: ciência, educação e ação nos quotidianos de São Carlos e Ibaté(SP). São Carlos ; 1999. [ Tese de Doutorado - Escola de Engenharia de São Carlos/USP].

SEMASA. Serviço Municipal de Água e Saneamento de Santo André. O "desenvolvimento" invade os mananciais. Água viva 1991a; 1:6-14. 
SEMASA. Serviço Municipal de Água e Saneamento de Santo André. Uma lei que resistiu ao tempo. Água viva 1991 b; 1:15-19.

Sobral HR. O meio ambiente e a cidade de São Paulo. São Paulo: Makron Books; 1996.

Tabanez MF, Padua SM, Souza MG, Cardoso MM, Garrido LMAG. Avaliação de trilhas interpretativas para educação ambiental. In: Padua SM, Tabanez MF, organizadores. Educação Ambiental caminhos trilhados no Brasil. $1^{*}$ ed. Brasília: Instituto de Pesquisas Ecológicas; 1997. p.73-88.

Takahashi MRF. Educação ambiental na represa Billings. Debates Sócios Ambientais - Formação de Agentes Ambientais 1998; III(10):22.

Tundisi JG. A bacia hidrográfica como unidade de pesquisa, gerenciamento e planejamento. São Paulo: CRHEA-USP; 1992.

Universidade de São Paulo. Faculdade de Saúde Pública. Biblioteca/CIR. Guia de Apresentação de Teses. São Paulo; 1998.

Vianna A, Menezes L, Iório MC, Ribeiro VM. Educação Ambiental: uma abordagem pedagógica dos temas da atualidade. São Paulo: Ação Educativa; 1996.

Viezzer ML, Ovalles $O$. Manual latino-americano de educ-ação ambiental. São Paulo: Editora Gaia; 1995.

Weid N. A formação de professores em educação ambiental à luz da Agenda 21. In: Padua SM, Tabanez MF, organizadores. Educação Ambiental - caminhos trilhados no Brasil. 1 ed. Brasilia: Instituto de Pesquisas Ecológicas; 1997. p.73-88. 
ANEXOS 


\section{ANEXO 1 - LOCALIZAÇÃO DA REGIÃO DE ESTUDO}

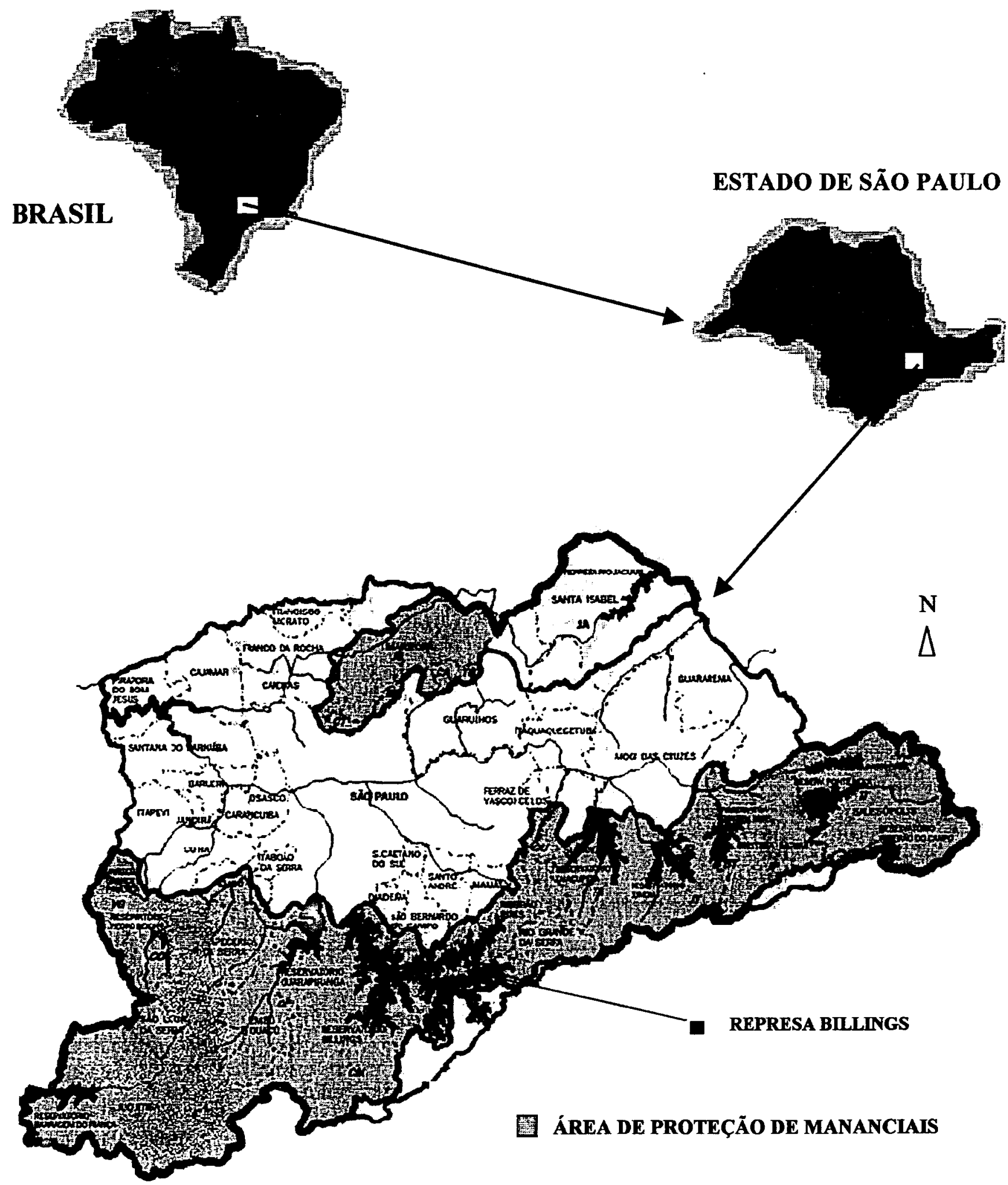

REGIÃO METROPOLITANA DE SÃO PAULO 


\section{ANEXO 2 - RELAÇÃO DAS ESCOLAS ANALISADAS}

\begin{tabular}{|c|c|c|c|c|c|c|}
\hline $\mathbf{n}^{0}$ & Nome da Escola & Endereço & Município & $\begin{array}{l}\mathrm{n}^{0} \mathrm{de} \\
\text { alunos }\end{array}$ & $\begin{array}{l}\text { Tipo de } \\
\text { escola } \\
\text { (grau) }\end{array}$ & $\begin{array}{l}\text { Situação } \\
\text { da E.A.* }\end{array}$ \\
\hline 1 & $\begin{array}{l}\text { E.E. Prof Fabiola } \\
\text { de Lima Goyano } \\
\end{array}$ & $\begin{array}{l}\text { Av. Antônio S. C. Bueno, } \\
34 \text { - Jardim União }\end{array}$ & Diadema & 1500 & $1^{\circ}$ e $2^{\circ}$ & - \\
\hline 2 & $\begin{array}{l}\text { E.E. Jardim } \\
\text { Inamar II }\end{array}$ & $\begin{array}{l}\text { Av. Antônio S.C. Bueno, } \\
1184 \text { - Jardim Inamar }\end{array}$ & Diadema & 1490 & $1^{\circ} \mathrm{e} 2^{\circ}$ & - \\
\hline 3 & $\begin{array}{l}\text { E.E. Prof. Pedro } \\
\text { Madóglio }\end{array}$ & $\begin{array}{l}\text { Av. Antônio S. C. Bueno, } \\
1322 \text { - Jd. Inamar }\end{array}$ & Diadema & 1066 & $1^{\circ}$ & 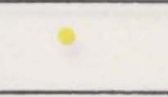 \\
\hline 4 & $\begin{array}{l}\text { E.E. Amadeu } \\
\text { Odorico de Souza }\end{array}$ & $\begin{array}{l}\text { Av. N. Sra. dos } \\
\text { Navegadores, 1139- } \\
\text { Bairro Eldorado }\end{array}$ & Diadema & 1560 & $1^{\circ}$ & $\bullet$ \\
\hline 5 & \begin{tabular}{|l|} 
E.E. Dr Átila \\
Ferreira Vaz \\
\end{tabular} & $\begin{array}{l}\text { Rua Bedejo, 70-Jardim } \\
\text { Navegantes }\end{array}$ & Diadema & 1450 & $1^{\circ}$ & e \\
\hline 6 & E.E. Simon Bolívar & $\begin{array}{l}\text { Rua Aiaça, } 61 \text { - Bairro } \\
\text { Eldorado }\end{array}$ & Diadema & 2250 & $1^{\circ} \mathrm{e} 2^{\circ}$ & - \\
\hline 7 & $\begin{array}{l}\text { E.E. Dr. José } \\
\text { Martins da Silva }\end{array}$ & $\begin{array}{l}\text { Rua dos Guatambus, } 69 \text { - } \\
\text { Jardim Sapopemba }\end{array}$ & Diadema & 2500 & $1^{\circ} \mathrm{e} 2^{\circ}$ & $\bullet$ \\
\hline 8 & \begin{tabular}{|l|} 
E.E. Jardim \\
Sapopemba II \\
\end{tabular} & $\begin{array}{l}\text { Rua Açucena, } 385 \text { - } \\
\text { Jardim Sapopemba }\end{array}$ & Diadema & 1200 & $1^{\circ}$ & - \\
\hline 9 & $\begin{array}{l}\text { E.E. Deputado } \\
\text { Gregório Bezerra }\end{array}$ & $\begin{array}{l}\text { Av. Afrânio Peixoto, } 281 \\
\text { - Vila Paulina }\end{array}$ & Diadema & 1200 & $1^{\circ}$ & $\bullet$ \\
\hline 10 & $\begin{array}{l}\text { E.E. Prof. } \\
\text { Domingos Peixoto } \\
\text { da Silva } \\
\end{array}$ & $\begin{array}{l}\text { Estrada do Alvarenga, s/n } \\
\text { - Jardim Laura }\end{array}$ & Diadema & 4500 & $1^{\circ}$ e $2^{\circ}$ & • \\
\hline 11 & \begin{tabular}{|l} 
E.E. Francisco \\
Cristiano Lima de \\
Freitas \\
\end{tabular} & $\begin{array}{l}\text { Estrada Poney Club, s/n - } \\
\text { Jardim das Orquídeas }\end{array}$ & $\begin{array}{c}\text { São } \\
\text { Bernardo do } \\
\text { Campo }\end{array}$ & 2440 & $1^{\circ} \mathrm{e} 2^{\circ}$ & $\bullet$ \\
\hline 12 & $\begin{array}{l}\text { E.E. Marco Antônio } \\
\text { Prudente de Toledo }\end{array}$ & $\begin{array}{l}\text { Estrada Poney Club, } \\
2120 \text { - Bairro das Palmas }\end{array}$ & $\begin{array}{c}\text { São } \\
\text { Bernardo do } \\
\text { Campo }\end{array}$ & 1665 & $1^{\circ} \mathrm{e} 2^{\circ}$ & - \\
\hline 13 & $\begin{array}{l}\text { E.E. Dr. José } \\
\text { Gonçalves de } \\
\text { Andrade Figueira }\end{array}$ & $\begin{array}{l}\text { Rua Fernando Pessoa, } \\
\text { 192- Jardim Represa }\end{array}$ & $\begin{array}{c}\text { São } \\
\text { Bernardo do } \\
\text { Campo }\end{array}$ & 1500 & $1^{\circ}$ & - \\
\hline 14 & E.E. Jacobe Cassebe & $\begin{array}{l}\text { Estrada da Cama Patente, } \\
200 \text { - Parque Esmeraldas }\end{array}$ & $\begin{array}{c}\text { São } \\
\text { Bernardo do } \\
\text { Campo } \\
\end{array}$ & 1720 & $1^{\circ}$ & - \\
\hline 15 & $\begin{array}{l}\text { E.E. Maristela } \\
\text { Vieira }\end{array}$ & $\begin{array}{l}\text { Rua Paraguaçu, } 240 \text { - } \\
\text { Jardim Telma }\end{array}$ & $\begin{array}{c}\text { São } \\
\text { Bernardo do } \\
\text { Campo } \\
\end{array}$ & 1400 & $1^{\circ}$ & $\bullet$ \\
\hline 16 & $\begin{array}{l}\text { E.E. Mário } \\
\text { Franciscon }\end{array}$ & $\begin{array}{l}\text { Estrada dos Casas, } 2650 \text { - } \\
\text { Jardim do Lago }\end{array}$ & $\begin{array}{c}\text { São } \\
\text { Bernardo do } \\
\text { Campo }\end{array}$ & 1825 & $1^{\circ}$ e $2^{\circ}$ & 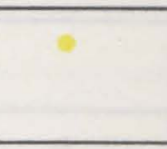 \\
\hline 17 & $\begin{array}{l}\text { E.E. Euclydes } \\
\text { Deslandes }\end{array}$ & $\begin{array}{l}\text { Av. Estrada dos Casas, } \\
2109 \text { - Jardim Ipê }\end{array}$ & $\begin{array}{c}\text { São } \\
\text { Bernardo do } \\
\text { Campo }\end{array}$ & 1600 & $1^{\circ}$ & $\bullet$ \\
\hline
\end{tabular}




\begin{tabular}{|c|c|c|c|c|c|c|}
\hline 18 & $\begin{array}{l}\text { E.E. Senador } \\
\text { Teotônio Vilela }\end{array}$ & $\begin{array}{l}\text { Rua Principal, } 30 \text { - Bairro } \\
\text { Demarchi }\end{array}$ & \begin{tabular}{|c|} 
São \\
Bernardo do \\
Campo
\end{tabular} & 680 & $1^{\circ}$ & $\bullet$ \\
\hline 19 & $\begin{array}{l}\text { E.E. Dr. Mathias } \\
\text { Octávio Rôxo } \\
\text { Nobre }\end{array}$ & $\begin{array}{l}\text { Estrada Galvão Bueno, } \\
4983 \text { - Bairro Batistini }\end{array}$ & $\begin{array}{l}\text { S. Bernardo } \\
\text { do Campo }\end{array}$ & 1950 & $1^{\circ}$ & $\bullet$ \\
\hline 20 & $\begin{array}{l}\text { E.E. Omar Donato } \\
\text { Bassani }\end{array}$ & $\begin{array}{l}\text { Estrada Ernesto Zabeu, } \\
253 \text { - Bairro Tatetos }\end{array}$ & $\begin{array}{l}\text { S. Bernardo } \\
\text { do Campo }\end{array}$ & 1450 & $1^{\circ}$ e $2^{\circ}$ & $\bullet$ \\
\hline 21 & $\begin{array}{l}\text { E.E. Prof }{ }^{3} \text { Faustina } \\
\text { Pinheiro Silva }\end{array}$ & $\begin{array}{l}\text { Rua Valdomiro Luiz, } 11 \text { - } \\
\text { Jardim N. Sra. de Fátima }\end{array}$ & $\begin{array}{l}\text { S. Bernardo } \\
\text { do Campo }\end{array}$ & 850 & $1^{\circ} \mathrm{e} 2^{\circ}$ & 9 \\
\hline 22 & $\begin{array}{l}\text { E.E. Dr. Adail Luiz } \\
\text { Miller }\end{array}$ & $\begin{array}{l}\text { Rua Matheus Demarchi, } \\
181 \text { - Bairro Demarchi }\end{array}$ & $\begin{array}{l}\text { S. Bernardo } \\
\text { do Campo }\end{array}$ & 1426 & $1^{\circ}$ e $2^{\circ}$ & $\bullet$ \\
\hline 23 & $\begin{array}{l}\text { E.E. Santa Dalmolin } \\
\text { Demarchi }\end{array}$ & $\begin{array}{l}\text { Rua Antônia Serafim } \\
\text { Zampieri, } 120 \text { - Bairro } \\
\text { Demarchi }\end{array}$ & $\begin{array}{l}\text { S. Bernardo } \\
\text { do Campo }\end{array}$ & 1200 & $1^{\circ}$ e $2^{\circ}$ & e \\
\hline 24 & \begin{tabular}{|l|} 
E.E. Dr. Francisco \\
Emygdio Pereira \\
Neto \\
\end{tabular} & $\begin{array}{l}\text { Rua Armando Backx, } \\
441 \text { - Bairro Demarchi }\end{array}$ & $\begin{array}{l}\text { S. Bernardo } \\
\text { do Campo }\end{array}$ & 1900 & $1^{\circ}$ e $2^{\circ}$ & $\bullet$ \\
\hline 25 & $\begin{array}{l}\text { E.E. Prof }{ }^{\mathrm{a}} \text {. Maria } \\
\text { Regina Demarchi } \\
\text { Fanini }\end{array}$ & $\begin{array}{l}\text { Rua Andréa Demarchi, } \\
45 \text { - Bairro Demarchi }\end{array}$ & $\begin{array}{l}\text { S. Bernardo } \\
\text { do Campo }\end{array}$ & 1414 & $1^{\circ}$ & - \\
\hline 26 & $\begin{array}{l}\text { E.E. Ayrton Senna } \\
\text { da Silva }\end{array}$ & $\begin{array}{l}\text { Rua Salim Mafhouo, s/n - } \\
\text { Bairro Terra Nova II }\end{array}$ & $\begin{array}{l}\text { S. Bernardo } \\
\text { do Campo }\end{array}$ & 1200 & $1^{\circ}$ e $2^{\circ}$ & 。 \\
\hline 27 & $\begin{array}{l}\text { E.E. Prof Maria } \\
\text { Pires }\end{array}$ & $\begin{array}{l}\text { Estrada Brasilico de } \\
\text { Lima, } 68 \text { - Bairro } \\
\text { Butujurú }\end{array}$ & $\begin{array}{c}\text { São } \\
\text { Bernardo do } \\
\text { Campo }\end{array}$ & 1100 & $1^{\circ} \mathrm{e} 2^{\circ}$ & - \\
\hline 28 & $\begin{array}{l}\text { E.E. Antônio } \\
\text { Caputo }\end{array}$ & $\begin{array}{l}\text { Rua Márciolio Conrado, } \\
280 \\
\text { Riacho Grande }\end{array}$ & $\begin{array}{l}\text { S. Bernardo } \\
\text { do Campo }\end{array}$ & 2183 & $1^{\circ}$ e $2^{\circ}$ & • \\
\hline 29 & $\begin{array}{l}\text { E.E. José Jorge do } \\
\text { Amaral }\end{array}$ & $\begin{array}{l}\text { Rua Francisco Mariotto, } \\
\text { 99- Bairro dos Fincos }\end{array}$ & $\begin{array}{l}\text { S. Bernardo } \\
\text { do Campo }\end{array}$ & 1977 & $1^{\circ}$ & - \\
\hline 30 & $\begin{array}{l}\text { E.E. Brazilia Tondi } \\
\text { de Lima }\end{array}$ & $\begin{array}{l}\text { Rua Isabel Andrade } \\
\text { Maia, } 733 \text { - Vila São José }\end{array}$ & $\begin{array}{l}\text { S. Bernardo } \\
\text { do Campo }\end{array}$ & 2604 & $1^{\circ}$ e $2^{\circ}$ & - \\
\hline 31 & $\begin{array}{l}\text { E.E. Metalúrgico } \\
\text { Luiz dos Santos }\end{array}$ & $\begin{array}{l}\text { Rua Primo Bechelliu, } \\
133 \text { - Bairro Selecta }\end{array}$ & $\begin{array}{l}\text { S.Bernardo } \\
\text { do Campo }\end{array}$ & 1100 & $1^{\circ}$ & 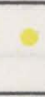 \\
\hline 32 & $\begin{array}{l}\text { E.E. Prof. Joaquim } \\
\text { M. Bernardes }\end{array}$ & $\begin{array}{l}\text { Av. Conde São } \\
\text { Lourenço, } 65 \text { - Jardim } \\
\text { Silvina }\end{array}$ & $\begin{array}{l}\text { S. Bernardo } \\
\text { do Campo }\end{array}$ & 1800 & $1^{\circ}$ & $\bullet$ \\
\hline 33 & \begin{tabular}{|l|} 
E.E. Prof ${ }^{a}$ Yolanda \\
Noronha do \\
Nascimento \\
\end{tabular} & $\begin{array}{l}\text { Av. Visconde de Cairú, } \\
252 \text { Jardim Silvina }\end{array}$ & $\begin{array}{l}\text { S. Bernardo } \\
\text { do Campo }\end{array}$ & 1402 & $1^{\circ}$ & • \\
\hline 34 & $\begin{array}{l}\text { E.E. Prof. Célio } \\
\text { Luiz Negrini }\end{array}$ & $\begin{array}{l}\text { Estrada Pedra Branca, s/n } \\
\text { - Bairro Areião }\end{array}$ & $\begin{array}{l}\text { S. Bernardo } \\
\text { do Campo }\end{array}$ & 1600 & $1^{\circ}$ & - \\
\hline 35 & E.E. Tito Lima & $\begin{array}{l}\text { Rua Sagres, } 115 \text { - Bairro } \\
\text { Estoril }\end{array}$ & $\begin{array}{l}\text { S. Bernardo } \\
\text { do Campo }\end{array}$ & 464 & $1^{\circ}$ & 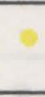 \\
\hline 36 & \begin{tabular}{|l} 
E.E. Prof. José \\
Brancaglione \\
\end{tabular} & $\begin{array}{l}\text { Rua Minerva, } 83 \text { - Vila } \\
\text { Suiça }\end{array}$ & Santo André & 1300 & $1^{\circ}$ & - \\
\hline 37 & $\begin{array}{l}\text { E.E. Prof Clotilde } \\
\text { Martins Zanei }\end{array}$ & $\begin{array}{l}\text { Av. Loreto, } 215 \text { - Jardim } \\
\text { Santo André }\end{array}$ & Santo André & 1661 & $1^{\circ} \mathrm{e} 2^{\circ}$ & - \\
\hline
\end{tabular}

Anexos A-3 


\begin{tabular}{|c|c|c|c|c|c|c|}
\hline 38 & $\begin{array}{l}\text { E.E. João Batista } \\
\text { Marigo Martins } \\
\end{array}$ & $\begin{array}{l}\text { Estrada do Pedroso, } 3898 \\
\text { - Jardim Riviera }\end{array}$ & Santo André & 2587 & $1^{\circ}$ e $2^{\circ}$ & - \\
\hline 39 & $\begin{array}{l}\text { E.E. Prof }{ }^{a} \text { Francisca } \\
\text { Helena Furia }\end{array}$ & $\begin{array}{l}\text { Rua Mico Leão Dourado, } \\
\text { 2361- Bairro Recreio } \\
\text { Borda do Campo }\end{array}$ & Santo André & 1581 & $1^{\circ} \mathrm{e} 2^{\circ}$ & - \\
\hline 40 & $\begin{array}{l}\text { E.E. Prof } \\
\text { Miquelina Pedroso } \\
\text { Magnari }\end{array}$ & $\begin{array}{l}\text { Rua Astorga, } \mathrm{s} / \mathrm{n} \text { - Parque } \\
\text { Andreense }\end{array}$ & Santo André & 433 & $1^{\circ}$ & - \\
\hline 41 & $\begin{array}{l}\text { E.E. Alípia Cabral } \\
\text { Silveira }\end{array}$ & $\begin{array}{l}\text { Rua da Estação, } 139 \text { - } \\
\text { Estação Campo Grande }\end{array}$ & Santo André & 50 & $1^{\circ}$ & - \\
\hline 42 & $\begin{array}{l}\text { E.E. Senador } \\
\text { Lacerda Franco }\end{array}$ & $\begin{array}{l}\text { Rua Ford, s/n - Bairro } \\
\text { Paranapiacaba }\end{array}$ & Santo André & 378 & $1^{\circ}$ & - \\
\hline 43 & \begin{tabular}{|l|} 
E.E. Dona Anna \\
Lacivitta Amaral
\end{tabular} & \begin{tabular}{|l} 
Rua Orlando Schurachio, \\
277 - Vila Sueli \\
\end{tabular} & $\begin{array}{l}\text { Ribeirão } \\
\text { Pires }\end{array}$ & 460 & $1^{\circ}$ e $2^{\circ}$ & e \\
\hline 44 & \begin{tabular}{|l} 
E.E. Prefeito \\
Francisco Arnoni
\end{tabular} & $\begin{array}{l}\text { Rua Marechal Humberto } \\
\text { A. C. Branco, } 190 \text { - Vila } \\
\text { Suely }\end{array}$ & $\begin{array}{l}\text { Ribeirão } \\
\text { Pires }\end{array}$ & 242 & $1^{\circ}$ & - \\
\hline 45 & \begin{tabular}{|l} 
E.E. Mário \\
Alexandre Foro \\
Nieri
\end{tabular} & $\begin{array}{l}\text { Rua Alfredo Mendes, } 25 \\
\text { - Estância Nobresse }\end{array}$ & $\begin{array}{l}\text { Ribeirão } \\
\text { Pires }\end{array}$ & 427 & $1^{\circ}$ e $2^{\circ}$ & - \\
\hline 46 & \begin{tabular}{|l|} 
E.E. Prof ${ }^{a}$ Ruth \\
Neves Sant'Anna \\
\end{tabular} & $\begin{array}{l}\text { Rua Dr. Jorge Tibiriça, } \\
02 \text { - Centro } \\
\end{array}$ & $\begin{array}{l}\text { Ribeirão } \\
\text { Pires }\end{array}$ & 790 & $1^{\circ} \mathrm{e} 2^{\circ}$ & - \\
\hline 47 & $\begin{array}{l}\text { E.E. Comendador } \\
\text { Emílio Sortino }\end{array}$ & $\begin{array}{l}\text { Rua Papa João XXIII - } \\
\text { Vila Suiça }\end{array}$ & $\begin{array}{l}\text { Ribeirão } \\
\text { Pires }\end{array}$ & 614 & $1^{\circ}$ & o \\
\hline 48 & $\begin{array}{l}\text { E.E. Dom José } \\
\text { Gaspar }\end{array}$ & $\begin{array}{l}\text { Rua Ozodoro Fontes, s/n } \\
\text { - Vila Aurora }\end{array}$ & $\begin{array}{l}\text { Ribeirão } \\
\text { Pires }\end{array}$ & 2070 & $1^{\circ} \mathrm{e} 2^{\circ}$ & - \\
\hline 49 & $\begin{array}{l}\text { E.E. Valentino } \\
\text { Redivo }\end{array}$ & $\begin{array}{l}\text { Rua Ana Lacivitta, } 28 \text { - } \\
\text { Parque do Governador }\end{array}$ & $\begin{array}{l}\text { Ribeirão } \\
\text { Pires }\end{array}$ & 776 & $1^{\circ}$ & $=$ \\
\hline 50 & E.E Di Cavalcanti & $\begin{array}{l}\text { Estrada do Caçula, } 100 \text { - } \\
\text { Jardim Caçula }\end{array}$ & $\begin{array}{l}\text { Ribeirão } \\
\text { Pires }\end{array}$ & 790 & $1^{\circ}$ & $\bullet$ \\
\hline 51 & E.E Forid Eid & $\begin{array}{l}\text { Rua Fagundes Varella, } \\
25 \text { - Jardim Caçula }\end{array}$ & $\begin{array}{c}\text { Ribeirão } \\
\text { Pires }\end{array}$ & 870 & $1^{\circ}$ e $2^{\circ}$ & $\bullet$ \\
\hline 52 & \begin{tabular}{|l|}
$\begin{array}{l}\text { E.E. Padre Giuseppe } \\
\text { Pisoni }\end{array}$ \\
\end{tabular} & $\begin{array}{l}\text { Rua Joaquim Lopes, } 222 \\
\text { - Vila Lopes }\end{array}$ & $\begin{array}{l}\text { Rio Grande } \\
\text { da Serra }\end{array}$ & 1600 & $1^{\circ} \mathrm{e} 2^{\circ}$ & - \\
\hline 53 & \begin{tabular}{|l|} 
E.E. Prof. Carlos \\
Roberto Guariento \\
\end{tabular} & $\begin{array}{l}\text { Rua dos Colibris, } 27 \text { - } \\
\text { Vila Niwa }\end{array}$ & $\begin{array}{l}\text { Rio Grande } \\
\text { da Serra }\end{array}$ & 440 & $1^{\circ}$ & e \\
\hline 54 & $\begin{array}{l}\text { E.E. Prof. Sebastião } \\
\text { Vayego de Carvalho } \\
\end{array}$ & $\begin{array}{l}\text { Rua Mauá, } 184 \text { - Vila } \\
\text { Conde }\end{array}$ & $\begin{array}{l}\text { Rio Grande } \\
\text { da Serra }\end{array}$ & 1017 & $1^{\circ} \mathrm{e} 2^{\circ}$ & • \\
\hline 55 & E.E. Antônio Lucas & $\begin{array}{l}\text { R. Benedito Cordeiro, } \\
255 \text { B. Novo Horizonte }\end{array}$ & $\begin{array}{l}\text { Rio Grande } \\
\text { da Serra }\end{array}$ & 454 & $1^{\circ}$ & - \\
\hline 56 & \begin{tabular}{|l|} 
E.E. Cassiano \\
Ricardo
\end{tabular} & $\begin{array}{l}\text { Rua Agostinho Cardoso, } \\
\text { s/n - Vila Figueiredo }\end{array}$ & $\begin{array}{l}\text { Rio Grande } \\
\text { da Serra }\end{array}$ & 1900 & $1^{\circ} \mathrm{e} 2^{\circ}$ & 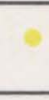 \\
\hline 57 & $\begin{array}{l}\text { E.E. Edmundo Luiz } \\
\text { de Nóbrega Teixeira }\end{array}$ & $\begin{array}{l}\text { Rua Jean Lieutand, } 280 \text { - } \\
\text { Bairro Santa Terza }\end{array}$ & $\begin{array}{l}\text { Rio Grande } \\
\text { da Serra }\end{array}$ & 2030 & $1^{\circ}$ e $2^{\circ}$ & 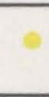 \\
\hline 58 & $\begin{array}{l}\text { E.E. Poetisa Cora } \\
\text { Coralina }\end{array}$ & $\begin{array}{l}\text { Estrada do Rio Pequeno, } \\
1147 \text { - Parque América }\end{array}$ & $\begin{array}{l}\text { Rio Grande } \\
\text { da Serra }\end{array}$ & 780 & $1^{\circ}$ & - \\
\hline
\end{tabular}

Anexos A-4 


\begin{abstract}
ANEXO 3 - QUESTIONÁRIO
UNIVERSIDADE DE SÃO PAULO

FACULDADE DE SAÚDE PÚBLICA

DEPARTAMENTO DE SAÚDE AMBIENTAL
\end{abstract}

"Levantamento de Projetos de Educação Ambiental em Escolas Públicas Estaduais das Áreas de Proteção de Mananciais da Represa Billings”

\title{
1 - DADOS GERAIS DA ESCOLA
}

1.1 - Nome:

1.2 - Endereço Completo: Rua Bairro $n^{\circ}$

CEP Tel. FAX

e-mail

1.3 - Número de:

Professores

Alunos

Funcionários

1.4 - Tipo de Escola:
( ) Pré-Escola
( ) Técnico
( ) $1^{\circ} \mathrm{Grau}$
( ) Magistério
( ) $2^{\circ} \mathrm{Grau}$ Município 
1.5 - A escola tem ou teve algum projeto de Educação Ambiental?

( ) $\operatorname{Sim}$

( ) Não Porquê?

OBS: em caso afirmativo responder campo 2 e 3

\section{2 - DADOS GERAIS SOBRE O PROJETO}

OBS: em caso de mais de um projeto, responder um questionário para cada.

2.1 - Nome do Projeto:

2.2 - Responsável pelo Projeto:

Função:

Nível de Escolaridade: ( ) Graduação ( ) especialização

( ) mestrado ( ) doutorado

Área de Formação:

Tem algum tipo de formação em Educação Ambiental

( ) Sim. Qual:

( ) Não

2.3 - Situação Atual do projeto:

( ) em implantação. Previsão para início

( ) em desenvolvimento. Data de início

( ) concluído. Data de início Data de conclusão

( ) interrompido. Por quê? Data de início: Interrompido em: 


\section{3 - CARACTERISTICAS DO PROJETO}

3.1- Descreva resumidamente os objetivos:

3.2 - O projeto obedece algum planejamento?

( ) $\mathrm{Sim}$

( ) Não

Em caso positivo, o planejamento é realizado:

( ) mensalmente

( ) anualmente

( ) bimestralmente

( ) foi realizado apenas no início

( ) semestralmente

3.3 - Abrangência. ( podem ser respondidas mais de uma alternativa):

( ) todas as séries.

( ) algumas séries. Quais?

( ) a comunidade em geral. De que forma?

( ) os pais de alunos. Como?

3.4 - O projeto é:
( ) disciplinar
( ) multidisciplinar

Disciplinas envolvidas: 
3.5 - Fonte Motivadora:
( ) Delegacia de Ensino
( ) Coordenadoria de Educação Ambiental/SMA
( ) Diretor
( ) Corpo discente
( ) Professor
( ) Comunidade
( ) Coordenação Pedagógica
( ) Outra. Qual?

3.6- Temas trabalhados no projeto:
( ) poluição do ar
( ) energia
( ) saúde da população ( ) poluição da água
( ) resíduos sólidos
( ) desenvolvimento sustentável
( ) poluição sonora
( ) moradia
( ) Agenda 21
( ) Outros:

3.7 - Onde são desenvolvidas a maior parte das atividades?
( ) na escola, dentro da sala de aula ou laboratório
( ) na escola, em dependências externas
( ) no bairro
( ) em outro local. Especificar:

3.8 - Duração do trabalho/atividades do projeto:

( ) ano letivo todo

( ) 1 semestre

( ) 3 bimestres

( ) 1 bimestre

( ) Outro. Especificar: 
3.9 -Atividades utilizadas com indicação de sua frequência:

\begin{tabular}{|l|l|l|l|l|}
\hline Atividades/Estratégias & MF & F & PF & N \\
\hline Aula expositiva/ Palestra & & & & \\
\hline Estudo de texto & & & & \\
\hline Pesquisa bibliográfica & & & & \\
\hline Seminário & & & & \\
\hline Debate & & & & \\
\hline Aula prática em laboratório & & & & \\
\hline Aula prática em campo & & & & \\
\hline Excursão/Estudo do meio & & & & \\
\hline Oficinas & & & & \\
\hline Campanhas educativas & & & & \\
\hline Comemorações & & & & \\
\hline Atividades com comunidade & & & & \\
\hline Confecção de Mat.Didático \\
(painéis, cartazes, folhetos) & & & & \\
\hline Exposições & & & & \\
\hline Projeção de Vídeos & & & & \\
\hline Discussão em Grupos & & & & \\
\hline Outros. Especificar: & & & & \\
\hline
\end{tabular}

MF- muito frequente $\mathbf{F}$ - frequente $\mathbf{P F}$ - pouco frequente $\mathrm{N}$ - nunca

3.10 - Como é feita a avaliação do projeto ( critérios utilizados) e com qual periodicidade? 
3.11 - Resumo das principais dificuldades, por ordem de importância:

3.12 - Resumo dos principais resultados, por ordem de importância:

3.13 - Qual o principal apoio financeiro?

3.14 - Qual o valor aproximado do custo anual do projeto?

3.15 - Existem instituições parceiras?

( ) Sim. Especificar:

( ) Não

Forma de Parceria:

( ) Apoio Técnico

( ) Recursos Didáticos

( ) Apoio Financeiro

( ) Recursos Humanos

( ) Outros. Especificar: 
3.16 - Textos e Documentos Oficiais que subsidiam o projeto:

( ) Agenda 21

( ) Tratado de Educação Ambiental para Sociedades Sustentáveis

( ) Conferência de Tbilisi

( ) Carta de Belgrado

( ) Programa Nacional de Educação Ambiental

( ) Programa Estadual de Educação Ambiental

( ) Lei de Proteção aos Mananciais

( ) Outros. Especificar:

3.17 - O responsável pelo projeto conhece alguns dos textos e documentos acima? Quais?

3.19 - O projeto aborda especificamente a problemática da degradação da Billings?.

( ) $\mathrm{Sim}$

( ) Não

OBS: em caso positivo, preencher o campo 4.

\section{4 - A REPRESA BILLINGS NO CONTEXTO DO PROJETO}

4.1- O projeto é específico sobre a Billings?

( ) Sim.

( ) Não Por quê? 
4.2- Descreva resumidamente o projeto/atividades.

4.3- $O$ projeto/atividade envolve a comunidade?

( ) Sim. De que forma?

( ) Não

4.4- A questão da ocupação irregular em áreas de mananciais é abordada?
( ) $\operatorname{Sim}$
( ) Não

4.5- O responsável pelo projeto conhece a legislação referente à proteção de mananciais?

( ) Sim. Qual?

( ) Não

4.6- As Leis de Proteção aos Mananciais tem sido abordada para subsidiar as atividades?

( ) Sim. De que forma?

( ) Não 


\section{ANEXO 4 - ROTEIRO DE ENTREVISTA}

COLETA DE DADOS SOBRE PROJETOS EXTERNOS DESENVOLVIDOS EM PARCERIA

1- Nome do Projeto;

2- Instituição Responsável ou Órgão Proponente;

3- Justificativa do Projeto;

4 Objetivos do Projeto;

5- Tempo Previsto para Duração do Projeto;

6- Público alvo / Área de Atuação

7- Escolas Participantes

8- Resultados Esperados 


\title{
ANEXO 5 - EXEMPLO DE PROJETO EXTERNO EM PARCERIA
}

\author{
Projeto “Água Limpa, Viva a Vida"- Programa de Educação \\ Ambiental
}

\section{Órgão Proponente: SEMASA - Serviço Municipal de Água e Saneamento de Santo André}

\section{JUSTIFICATIVA:}

O município de Santo André compreende uma área de aproximadamente $170 \mathrm{Km}^{2}$. Cerca de $50 \%$ deste território encontra-se na Área de Proteção aos Mananciais da Bacia Billings: nascentes e reservatórios dos quais captamos água para uso e abastecimento. Em função da importância ambiental, esta área encontra-se sob uma legislação especial, a Lei de Proteção das Bacias Hidrográficas dos Mananciais de Interesse Regional do Estado de São Paulo, de 1997, visando garantir a qualidade da água da Represa Billings, responsável pelo abastecimento de água do Grande $\mathrm{ABC}$ e de parte da Região Metropolitana de São Paulo.

A preservação desta área tem sido afetada significativamente pelos impactos decorrentes das ações antrópicas locais. A ocupação desordenada, em consequência de diversos fatores sócio-econômicos e políticos, tem acarretado sérios problemas de saneamento e degradação ambiental da região.

O SEMASA, através do Departamento de Gestão Ambiental, tem como ação prioritária a proteção e preservação dos mananciais, pois é nessa parte da cidade que se encontra o potencial de desenvolvimento do município, devendo ser protegida tanto para assegurar que a água continue chegando em quantidade e qualidade nas residências e nas indústrias como para impedir a degradação da região. 
Neste sentido, a educação ambiental é prioritária nas escolas localizadas na área de mananciais. Oferecer educação ambiental continuada e ininterrupta, com apoio técnico e operacional aos educadores que trabalham nessa região é o objetivo deste programa.

\section{OBJETIVOS:}

- Promover a capacitação de educadores através do desenvolvimento de atividades que permitam a compreensão e a reflexão sobre os problemas sócio-ambientais da região;

- Fomentar discussões acerca dos problemas ambientais visando a melhoria do meio ambiente local;

- Realizar ações visando o aprimoramento do conhecimento, a troca de experiências e a sensibilização dos educadores como agentes multiplicadores;

- Promover a preservação ambiental e o uso dos recursos naturais.

\section{PERÍODO:}

O programa de Educação Ambiental ÁGUA LIMPA, VIVA A VIDA será desenvolvido no período de 1999 e 2000.

\footnotetext{
ÁREA DE AÇÃo:

As atividades estão sendo desenvolvidas nas áreas de proteção aos mananciais.
} 


\section{PÚBLICO ALVO:}

O Programa de Educação Ambiental ÁGUA LIMPA, VIVA A VIDA está atendendo um grupo de 25 professores (05 por escola) representando todas as escolas estaduais de Santo André situadas nas áreas de mananciais:

- EEPG Alipia Cabral Silveira

- EEPG Francisca Helena Furia

- EEPG Miquelina P. Magnani

- EEPSG João B. Marigo Martins

- EEPSG Senador Lacerda Franco
Estação Campo Grande

Recreio da Borda do Campo

Parque Andreense

Jardim Riviera

Paranapiacaba

\section{METAS:}

- Realizar três módulos, somando no total 88 horas de atividades teórico-práticas, sobre os temas relacionados ao meio ambiente em Santo André;

- Promover encontros, no decorrer dos módulos temáticos, entre todos os educadores e a equipe de coordenação do projeto, para a troca de experiências, avaliação das atividades e encaminhamento das atividades do projeto;

- Resgatar a percepção e os conhecimentos dos próprios educadores sobre o meio ambiente, através de dinâmicas e discussões em grupo, como ponto de partida para as atividades do projeto;

- Aplicar metodologias educativas expositivas, lúdicas e artísticas em todos os módulos de forma a envolver o educador no processo de aprendizagem;

- Implantar um calendário ecológico, com datas comemorativas significativas para o meio ambiente, em cada uma das escolas, sob responsabilidade da implantação pelo educador, permeando as atividades entre os módulos; 
- Realizar visitas e atividades de campo em locais representativos e ilustrativos dos aspectos do meio ambiente ao município;

- Desenvolver um módulo de elaboração de projetos de ação em educação ambiental como fechamento do curso, no qual cada educador desenvolverá um projeto para a sua escola e comunidade;

- Acompanhar e assessorar os projetos elaborados pelos educadores. 


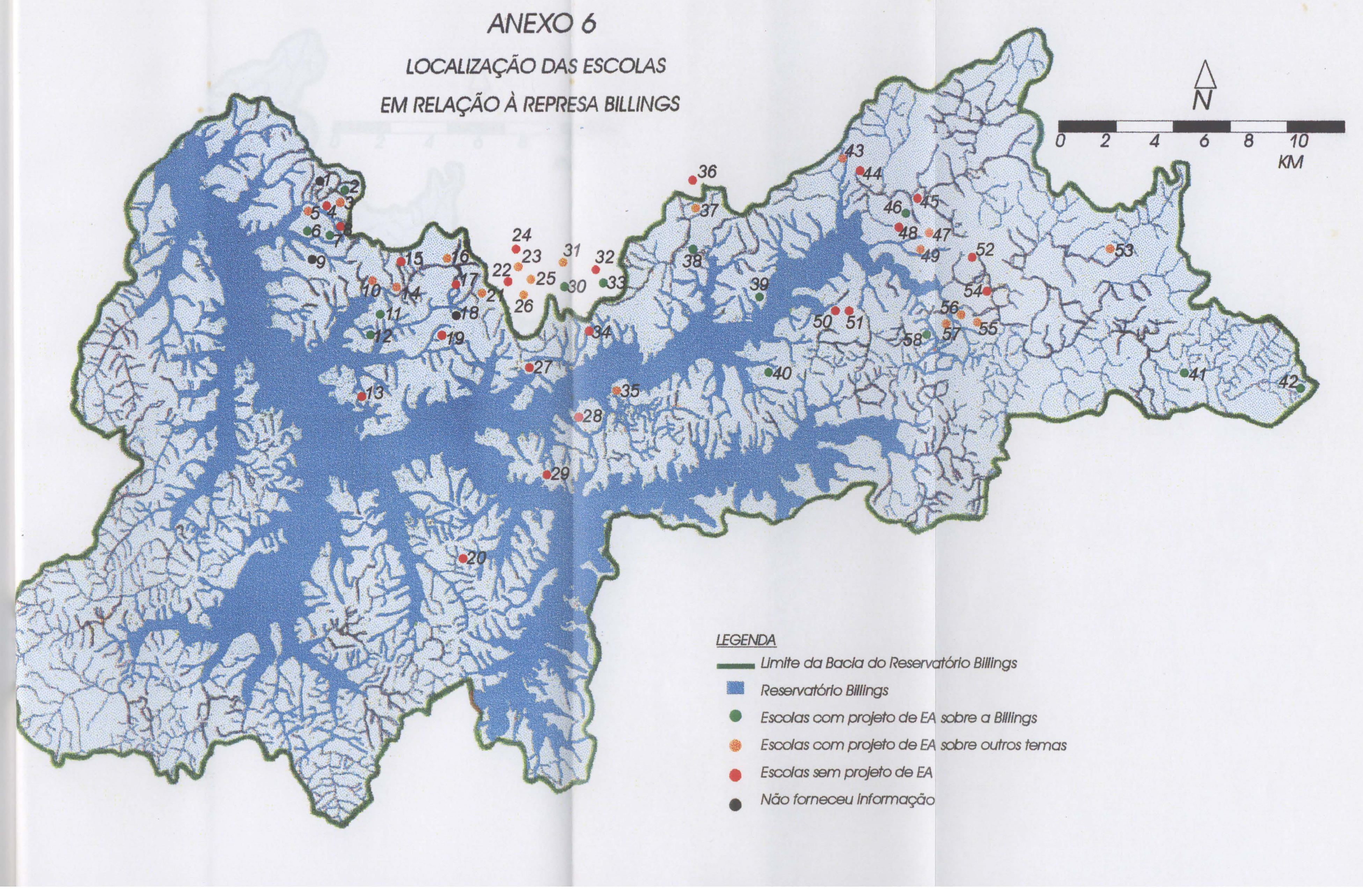




\section{ANEXO 7}

SITUAÇÃO ATUAL DOS PROJETOS

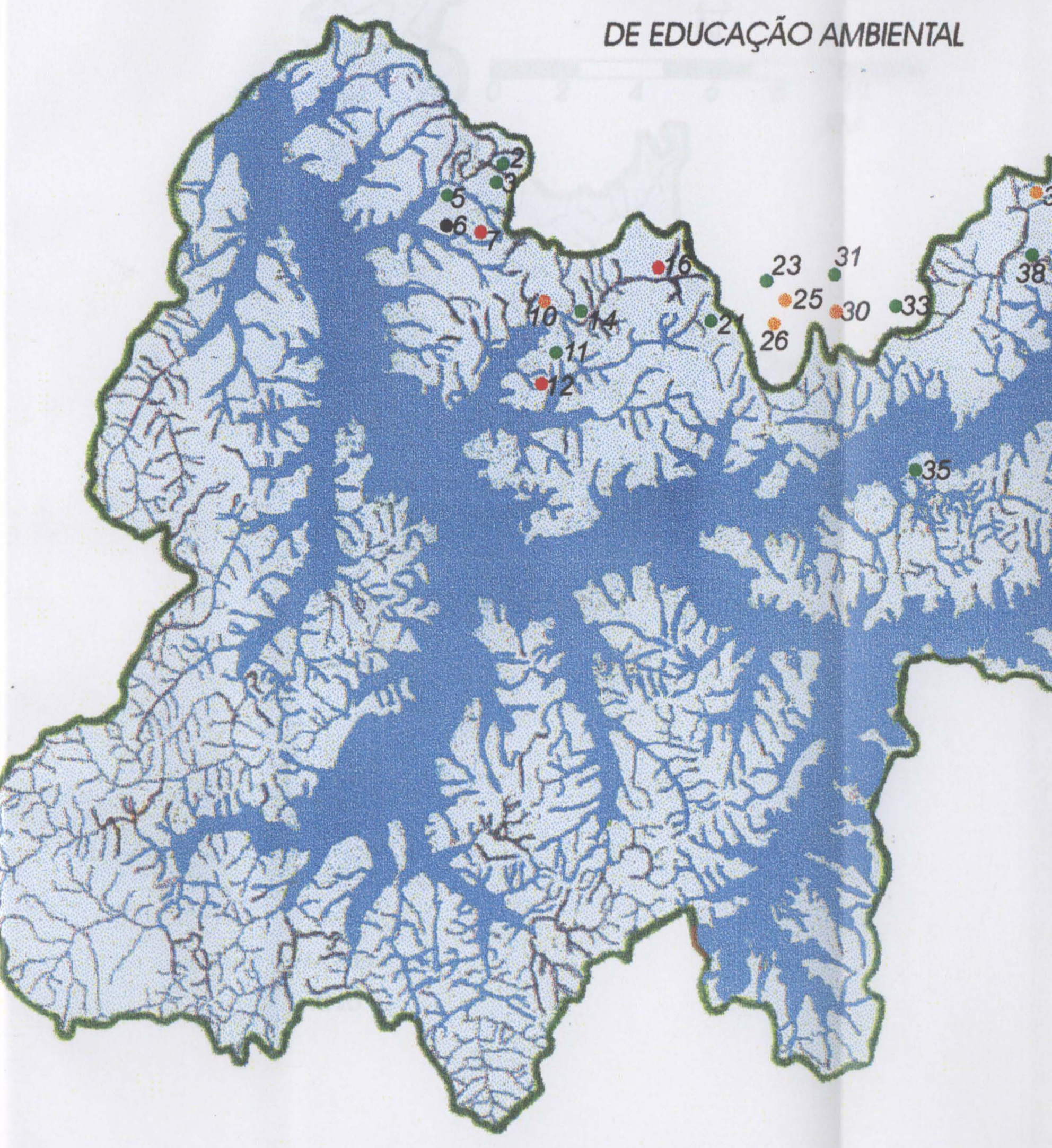

- Lmite da Bacla do Reservatório Billings

Reservatório Billings

- Projeto de EA em Desenvolvimento

- Projeto de EA em Implantação

- Projeto Concluído

- Projeto Interrompido 


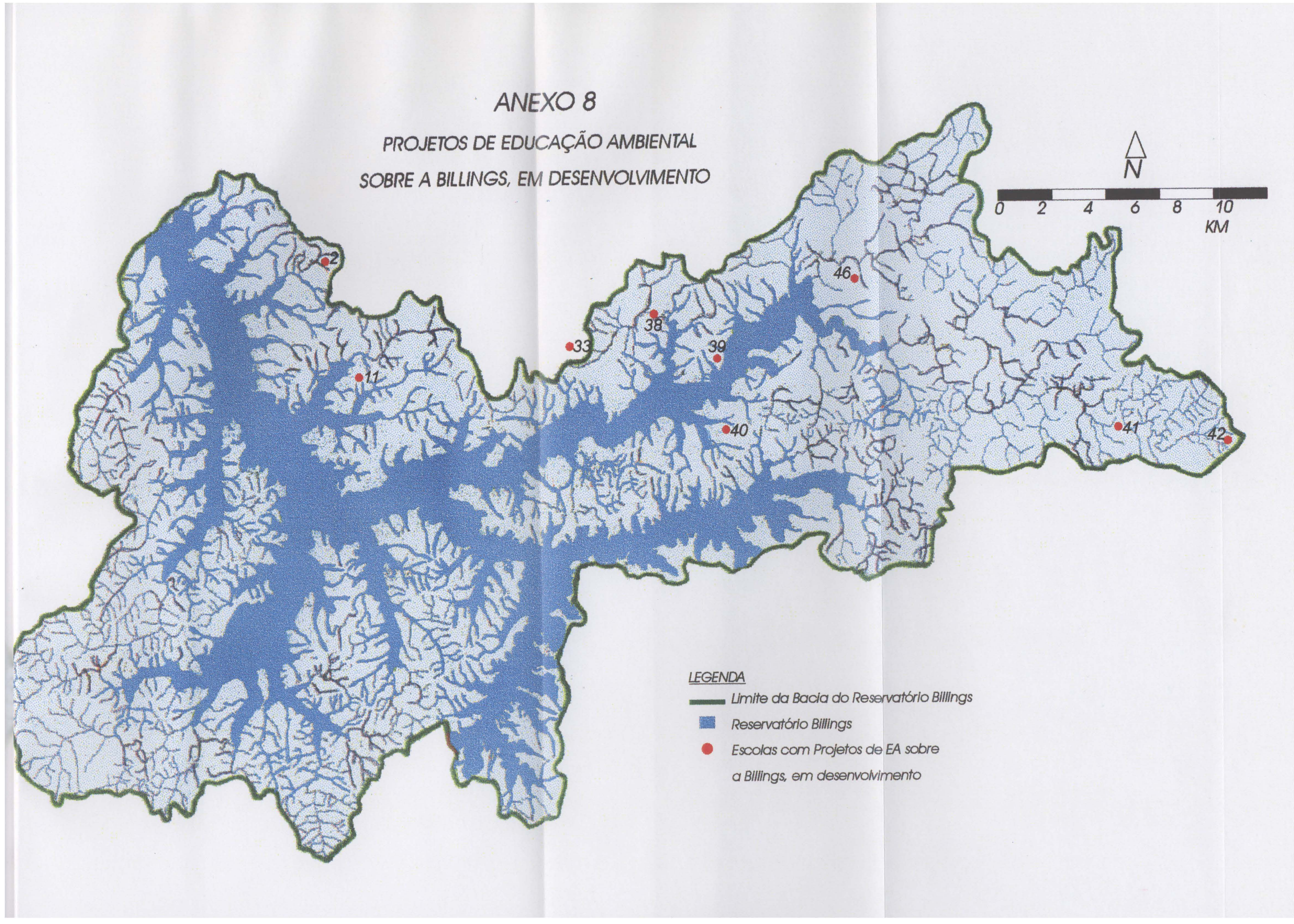

